\title{
Teaching and learning another language strategically
}

(La enseñanza y el aprendizaje estratégico de otro idioma)

Rigoberto Castillo, Ph.D 


\title{
Teaching and learning another language strategically
}

\author{
(La enseñanza y el \\ aprendizaje estratégico
} Rigoberto Castillo, Ph.D. 


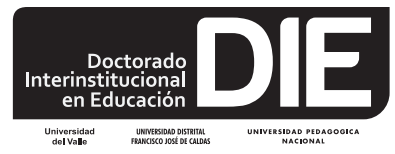

Comité Editorial Interinstitucional-CAIDE

Carlos Javier Mosquera Suárez

Director nacional

Alexander Ruíz Silva

Coordinador DIE,

Universidad Pedagógica Nacional

Sandra Soler Castillo

Directora DIE,

Universidad Distrital Francisco José de Caldas

\author{
Jaime Humberto Leiva \\ Coordinador DIE, \\ Universidad del Valle
}

Comité Editorial CADE

Sandra Soler Castillo

Presidenta CADE

William Manuel Mora Penagos

Representante grupos de investigación: Interculturalidad, Ciencia y Tecnología-INTERCITEC, y del Grupo Didáctica de la Química-DIDAQUIM, del Énfasis de Educación en Ciencias.

Dora Inés Calderón

Representante de los grupos de investigación:

Moralia, Estudios del Discurso, Filosofía y Enseñanza de la Filosofía, Grupo de investigación

Interdisciplinaria en Pedagogía de Lenguaje y las Matemáticas-GIIPLyM y Jóvenes, Culturas y Poderes, del Énfasis de Lenguaje y Educación.

\section{Martín Eduardo Acosta Gempeler}

Representante de los grupos de investigación:

Grupo de Investigación Interdisciplinaria en Pedagogía de Lenguaje y las Matemáticas

GIIPLyM, Matemáticas Escolares Universidad Distrital-MESCUD y Edumat, del Énfasis de Educación Matemática.

Bárbara García Sánchez

Representante de los grupos de investigación: Formación de Educadores, del énfasis de Historia de la Educación, Pedagogía y Educación Comparada.
UNIVERSIDAD DISTRITAL

FRANCISCO JOSÉ DE CALDAS

\section{Roberto Vergara Portela}

Rector (E)

Universidad Distrital Francisco José de Caldas

\section{Borys Bustamante Bohórquez}

Vicerrector Académico

Universidad Distrital Francisco José de Caldas

ISBN impreso: 978-958-8832-71-5

ISBN digital: 978-958-8832-72-2

Primera edición, 2014

(C) U. Distrital Francisco José de Caldas

\section{Preparación Editorial}

Doctorado Interinstitucional en Educación Sede U. Distrital Francisco José de Caldas http://die.udistrital.edu.co

\section{Elban Gerardo Roa Díaz}

Asistente Editorial

eventosdie@udistrital.edu.co

\section{Fondo de publicaciones}

U. Distrital Francisco José de Caldas

Cra. 19 No. 33-39. Piso 2.

PBX: $(57+1)$ 3238400, ext. 6203

publicaciones@udistrital.edu.co

Corrección de estilo

\section{Luisa Juliana Avella Vargas}

Impreso en Javegraf

Bogotá, Colombia, 2014

Prohibida la reproducción total o parcial de la presente obra por cualquier medio sin permiso escrito de la Universidad Distrital Francisco José de Caldas. 


\title{
Teaching and learning another language strategically
}

\author{
\begin{tabular}{r|l} 
(La enseñanza y el & Rigoberto Castillo, \\
aprendizaje estratégico & Ph.D. \\
dle otro idlioma) &
\end{tabular} \\ \begin{tabular}{r|l} 
(La enseñanza y el & Rigoberto Castillo, \\
aprendizaje estratégico & Ph.D. \\
dle otro idioma) &
\end{tabular} \\ \begin{tabular}{r|l} 
(La enseñanza y el & Rigoberto Castillo, \\
aprendizaje estratégico & Ph.D. \\
dle otro idlioma) &
\end{tabular} \\ \begin{tabular}{r|l} 
(La enseñanza y el & $\begin{array}{l}\text { Rigoberto Castillo, } \\
\text { Ph.D. }\end{array}$ \\
aprendizaje estratégico & \\
de otro idioma) &
\end{tabular}
}




\section{El Autor}

Rigoberto Castillo obtuvo el grado de Doctor of Philosophy y Master of Arts de la Universidad de Texas, sede Austin E.U. Estudió Filología e Idiomas en la Universidad Nacional de Colombia. Profesor del Doctorado Interinstitucional en Educación, Sede Universidad Distrital Francisco José de Caldas. Ha sido profesor de la Licenciatura en inglés y Director del Instituto de Lenguas de la misma universidad. Pertenece al grupo de investigación Formación de Educadores y es miembro del Comité Científico de How Journal, GISTJournal, y LACLIL Journal.

Presidió la Asociación Colombiana de Profesores de inglés, ASOCOPI y recibió la distinción de Premio Nacional Claire de Silva por su contribución al campo de la enseñanza. Becario Fulbright y profesor visitante en las universidades: de Texas at Austin, Nacional de Colombia, Pontificia Bolivariana, Pedagógica y Tecnológica de Colombia, La Gran Colombia, Libre de Colombia y Universidad de Córdoba en Montería. Asesor de la Universidad de la Sabana y de la Universidad Católica de Colombia. Consultor de casas Editoriales y de la compañía internacional de teatro The Performers Educational Plays.

Este libro fue nominado al premio internacional "The Macmillan Education Award for Innovative Writing" que otorga la organización ELTons del Reino Unido.

\section{About the author}

Professor Castillo holds a Ph.D and an M.A. from The University of Texas at Austin. He studied philology and Languages at Universidad Nacional de Colombia. He teaches at the Doctorado Interinstitucional en Educación, Universidad Distrital Francisco José de Caldas, Bogotá, Colombia. He has taught at the undergraduate TEFL program and directed the foreign language institute of the same university. He belongs to the research group "Teacher Education" and belongs to the scientific committees of the Journals HOW, GIST and LACLIL.

Past President of the Colombian Association of Teachers of English (ASOCOPI) and recipient of the Claire de Silva National Award for services to the TESOL profession. Fulbright scholar and lecturer at The University of Texas at Austin. Guest lecturer at Universidad Nacional de Colombia, Universidad Pontificia Bolivariana, Universidad Pedagógica y Tecnológica de Colombia, Universidad La Gran Colombia, Universidad Pedagógica Nacional, Universidad Libre de Colombia, and Universidad de Córdoba in Montería. Consultant for Universidad de La Sabana and Universidad Católica de Colombia. He has served as Consultant for publishing houses and for the international company The Performers Educational Plays.

This book was nominated to the international prize "The Macmillan Education Award for Innovative Writing" bestowed by the U.K based Organization ELTons. 


\section{Tabla de contenido}

$\begin{array}{ll}\text { Prólogo: Bitácora de este caleidoscopio para docentes } & 7\end{array}$

$\begin{array}{ll}\text { Acknowledgments } & 13\end{array}$

$\begin{array}{ll}\text { Introduction } & 15\end{array}$

\section{Chapter I}

\section{Theories that illuminate Strategic Learning $\quad 19$}

1. Information Processing Theory 20

2. The Dimensions of Literacy 23

3. Communicative Competence 25

4. Strategic Learning: Background, theory and research 28

\section{Chapter II}

Strategic learning and reading competence $\quad 37$

$\begin{array}{ll}\text { A structure for strategic learning and reading } & 40\end{array}$

Types of knowledge reading calls for and their corresponding strategies $\quad 42$

1. Knowledge of the content and experience (images and concepts) call for strategies for generating ideas (identification of macroframe)

2. Procedural knowledge to organize the content calls for strategies for organizing ideas

3. Knowledge of written discourse conventions call for editing strategies The control and verification of understanding runs through the revision for coherence

4. Procedural knowledge required to apply the other types of knowledge in comparing a written discourse call for strategies for recognizing relevance (clarification and simplification)

5. Procedural knowledge required to evaluate a written discourse calls for strategies for questioning textual information (taking a critical stand)

Discussion

\section{Chapter III}

\section{Strategic learning and listening competence $\quad 55$}

Word-level factors

Sentence-level factors

Discourse-level factors

Task-processing factors

A structure for the development of listening

Discussion 


\section{Chapter IV}

Strategic learning and speaking competence $\quad 73$

A structure for promoting L2 speaking

1. Knowledge of the content and experience (images and concepts) calls for strategies for recognizing ideas (identification of macroframe) $\quad 74$

2. Procedural knowledge to organize the content calls for strategies for organizing ideas (identification of schema)

3. Knowledge of conventions of speaking calls for strategies for editing ideas (control and verification)

4. Procedural knowledge required to apply the other types of knowledge in comparing a spoken discourse calls for strategies for recognizing relevance of ideas and coherence

\section{Chapter V}

\section{Strategic learning and writing competence $\quad 81$}

$\begin{array}{ll}\text { A theory of writing as a recursive process } & 81\end{array}$

A structure for strategic learning and writing 83

1. Knowledge of the content 85

2. Procedural knowledge to organize the content 87

3. Knowledge of conventions of writing 92

4. Procedural knowledge required to apply the other types of knowledge in comparing a written product 93

Discussion 94

\section{Chapter VI}

Implications of strategic learning for language education

References

Further reading 


\section{Prólogo}

\section{Bitácora de este caleidoscopio para docentes}

El lenguaje en su acepción más amplia, o mejor aún, las áreas de los currículos como las lenguas y las literaturas, son asignaturas fundantes en la escuela. Y si somos más rigurosos, el lenguaje como facultad mental que nos permite representar el mundo es fundante no solo en la academia, sino en la vida misma de los seres humanos. Y por esta sencilla razón, los docentes de lenguas, herederos a través de los códigos articulados, tenemos la responsabilidad fundacional de contribuir a la construcción cognitiva de nuestros estudiantes. Así, el conocimiento construido mediante el incentivo de estrategias nutre la calidad y la velocidad de la construcción de redes neuronales como expresión de las experiencias en el mundo. Este proceso neurológico es una camino de ida y vuelta, tan complejo como hermoso.

El debate es ya denso (desde la legendaria de Bunge-Chosmky hasta los desarrollos modernos de la neurolingüística), entre innatismo y estímulo social entre facultad de procesos cognitivos y el hacer material de los seres humanos, entre las redes de neuronas incentivadas por la realidad y la experiencia de la vida, exigiendo un lenguaje sistematizado para atraparla. En este punto, el papel del docente surge como hacedor de estrategias para propiciar, facilitar y orientar el encuentro del estudiante entre su ser, los problemas y la sociedad, mediante la construcción de los mecanismos lingüísticos más eficientes. Justamente, el conocimiento estratégico, desde la lingüística del lenguaje primero, luego desde la lengua y posteriormente desde otros códigos científicos como las matemáticas, las ciencias sociales, la biología, etc. (la filosofía es una meta-ciencia envolvente), ha venido constituyéndose en el centro del debate de la pedagogía moderna. Este camino moderno de la enseñanza actual alrededor de los estudios que comparten este rótulo de conocimiento estratégico responden a la necesidad de condensar en sus propuestas pedagógicas los mecanismos estimulantes a manera de puentes entre el desarrollo cognitivo, los interrogantes del mundo y la construcción sistemática del saber de los estudiantes en ámbitos de 
aula y acompañados por quienes manipulan estas técnicas y tecnologías para aprender a conocer y comprender, los profesores.

El conocimiento estratégico evoluciona a lo largo de fases traslapadas e interconectadas por contextos y motivaciones: un primer nivel fáctico, reconocimiento de esquemas organizados, inventario de los elementos constitutivos de los códigos; un segundo nivel funcional, vinculado con el cómo usar las herramientas del lenguaje para el hacer en el mundo; y un tercer nivel meta-cognitivo, que da cuenta del saber elegir el cuándo y el cómo implementar estos desarrollos en una producción cada vez más autónoma (como sujeto), creativa (como diversidad) e ideológica (visión de mundo). La descripción teórica sustenta los diseños presentados por Rigoberto CastiIlo en este caleidoscopio sobre el aprendizaje estratégico, a la manera de un marco pedagógico para la elaboración de didácticas; mostramos el puente entre la teoría cognitiva, la problemática educativa y la aplicación de estrategias, tanto en la construcción de conocimiento como en la solución de problemas en contexto, privilegiando los ámbitos cognitivo, comunicativo, lúdico y relacional.

La acción comunicativa se entiende (entre otros, Habermas) no en el mero sentido de estrategias para el éxito con arreglo a fines (sin que el otro importe), sino de un modo trascendente para el entendimiento y el diálogo inter-subjetivo, en la construcción del mundo no solo eficiente sino eficaz, si incluimos a los otros en nuestra construcción, al menos desde una ética de mínimos universales.

Las estrategias se desarrollan en simultaneidad y confluencia entre los sujetos actuantes (profesores, estudiantes y sociedad) y los contextos sociales; las estrategias no son meros mecanismos aislados, son didácticas desde el punto de vista de su diseño y son habilidades cognitivas desde la capacidad de codificar la experiencia del mundo a través del lenguaje. Así, las estrategias en acción son una cara la moneda. La otra cara es el hacer cosas con estas estrategias, porque el lenguaje como capacidad (no mero código) solo se nos revela en su producto, y la complejidad de este producto reconstruye la capacidad para volver sobre el mundo en su lectura.

El conocimiento debe ser construido de modo profundo y amplio. El pensar requiere mucho más que los procesos lineales, deben ser amplios, situacionales e interconectados. Los estudiantes no necesitan solamente darse cuenta de lo que es el conocimiento, necesitan aprender a usarlo, cuándo y dónde usarlo, y por qué usarlo. La competencia científica tendría que ser 
mucho más que la mera posesión de un volumen de conocimiento, esta posesión tendrá poco valor si no es usada del modo más adecuado (Pushkin, 2007, p. 10).

De este modo, el conocimiento estratégico no se reduce a un destornillador para sacar tornillos, sino al modo como nuestro cerebro condensa la mano y la herramienta, el problema y su solución; la ejecución continua del destornillador facilita la acción, diluyéndola hasta volverla una forma más de nuestro lenguaje, sin que nos percatemos de ello, hasta llegar a las «formas hechas» o consabidos de Bajtín, muy cercanos a las frases verbales compuestas o los refranes populares e incluso las jergas de la ciencia.

Los docentes pueden disponer en este libro de una filosofía y metodología para la construcción de un ambiente de aprendizaje estratégico, en un diálogo permanente entre el caso como ilustración de un acto de habla específico y el carácter universal del conocimiento construido. Y queremos señalar esta universalidad como referencia esencial de aquello que se valida por la comunidad en general, más allá de los caprichos del docente en particular, o de las tradiciones de saber no reconocidas o en decadencia. Esta perspectiva universal, tanto de los principios como de los logros, permitirá la fácil coordinación con los parámetros ministeriales y de la comunidad internacional. El saber reconocido, no obstante, no debe confundirse con el absolutismo; se debe alcanzar el equilibrio valorativo del hacer y sus productos en relación con su aceptación y utilidad objetivada dentro de los marcos institucionales.

Las estrategias emergen desde el sujeto y el texto hacia los contextos, desde los actos de habla más elementales hacia complejos discursivos. Los estudios señalan el carácter más objetivo, concreto y dirigido de las estrategias comparado con la delimitación de las habilidades. El pensamiento estratégico debe evaluar las habilidades y producir las estrategias en cada momento, sobreponiéndose a reducir la estrategia a la temática del momento y, por el contrario, integrando los aspectos emocionales y problémicos con los contextuales en aras de construir un escenario de aprendizaje vinculante a plenitud en todos los mundos posibles del estudiante, desde su pasado, sus mundos fantasiosos, hasta su realidad inmediata. Este proceso deberá evolucionar desde el traslapo de los actos locucionarios (información), ilocucionarios (intención) y perlocucionarios (efecto pragmático), en camino creciente desde el texto hacia los contextos e incluso desde los contextos hacia los textos, en el proceso complejo entre producir e interpretar, igual- 
mente en el proceso de interpretar y producir, en un circuito permanente de interacción (Foucault, Bourdieu, Van Dijk, entre otros).

En realidad, son instancias valorativas presentes y desgranadas en la praxis y en contextos. Aprender a aprender, abstraer las reglas desde el funcionamiento de los sistemas en uso y potenciar el uso complejo de los sistemas mediante la manipulación consciente e inconsciente de las reglas interiorizadas, hasta incluso expandir los sistemas mismos y sus relaciones con otros sistemas hasta los límites del pensamiento complejo (Morin, entre otros); porque todos los mundos son posibles en nuestra mente y las estrategias son esa palanca capaz de desplegar el horizonte a nuestro servicio.

El aprendizaje estratégico potenciando el futuro aprendizaje en ámbitos de productividad (eficiencia y eficacia), propiciando las didácticas diseñadas, entendiendo la eficacia como hacer más en el mismo tiempo y recursos, entendiendo que se es además eficiente si se cumple lo anterior sin desmedro de efectos negativos colaterales. En la industria puede ser la contaminación, en nuestro hacer educativo el estrés, el afecto truncado y otros costos colaterales.

Las redes neuronales creadas en este proceso de aprendizaje estratégico son el primer eslabón para construir redes sociales entre personas capaces de trabajar tanto individualmente como en equipo. Y además, propiciando este encadenamiento relacional en un encuentro con lo diverso, con la productividad y con el otro. Pues conocer es divertirse (di-versión), es encontrar caminos relacionales, comparar y establecer diferencias en aras de construir tejidos complejos en nuestro lenguaje con el fin de leer igualmente la complejidad del mundo.

Es la lúdica de la comunicación humana, entendida como el equilibrio entre el mundo y nuestro lenguaje en un estado espiritual colmado por la armonía entre los signos y nuestros sueños. Pues quien tiene mayor capacidad para aprender, tiene mayor posibilidad de ser feliz. Y en el diálogo con la lúdica como esencia de lo humano, buscaremos mostrar los vínculos de los códigos de las lenguas naturales con otros códigos, y desde otros códigos podemos enseñar las lenguas: los códigos lingüísticos pueden ser enseñados a través de la actividad corporal; las posiciones de un jugador en un partido de fútbol o cualquier otro deporte, puede proporcionarnos un escenario análogo a las secuencias de palabras en temas de gramática (Moreno, 2000); las figuras de la geometría pueden ser narrativizadas y, en diálogo con la lingüística, las jerarquías epistemológicas del cuadrado, la 
circunferencia y la línea exponen una gramática tan pictórica como funcional (Abbott 1884,1994); las categorías gramaticales pueden ser personificadas para exponer «la psicología» de su régimen de combinatoria, pues no será lo mismo ser verbo que preposición en ese mundo posible (ver cuento de lbáñez).

Uno de los mayores desafíos de las pedagogías y didácticas modernas, especialmente cuando están vinculadas con la enseñanza de las lenguas, es el desarrollo de escenarios de aula tendientes a traslapar, integrar y procesar los elementos ortográficos, sintácticos, morfológicos y semánticos, tradicionalmente presentados de modo aislado, e incluso las viejas prácticas de listas de vocabulario, de repetición mecánica de estructuras y manejos de reglas sin contexto. El papel del docente será promover las habilidades del estudiante a través de los conceptos teóricos aplicados a la resolución de problemas. Si tras este libro del profesor Castillo logramos buena parte de esta filosofía, entonces nuestros años como docentes nos habrán regalado un puente para seguir tejiendo el lenguaje a través de las didácticas de las lenguas al servicio de la enseñanza como saber fundador de cognición y herramientas con repercusión sobre todas las demás áreas del conocimiento.

Enrique Ferrer Corredor

Ph.D. en Lingüística y literatura española UNED, Madrid, España 


\section{Acknowledgments}

Being aware that knowledge is a social construction, I have to recognize the many individuals and institutions that have contributed to the writing of this book. First, I would like to thank my family, who supported my efforts and gave up their share of time to help me through the elaboration of the book. Second, I acknowledge the support of Universidad

Distrital Francisco José de Caldas. Third, I would like to express my gratitude to the reviewers: Dr. Raúl Mora, Dr. Harold Castañeda, Dr. Enrique Ferrer, Dr. Nancy Lemberger and Nicole Chartier. As well as to the readers of drafts: Simon

Dickinson, Gerson Correa, Sonia Jerez, Imelda Zorro, Ana

Milena Morales, Sandra Milena Rico and Tatiana Castillo. Fourth, my appreciation goes to Ms. Magdalena Benavides and the Ribón-Castillo family, whose supported my library work in the U.S. Finally, thanks to Ms. Elizabeth Rodríguez,

Sonia Castrillón and Sandra Macías, whose devotion to education has been a source of inspiration. 


\section{Introduction}

"The best way to become acquainted with a subject is to write a book about it.»

Benjamin Disraeli

(The quotes at the beginning or end of a section appear in http// www.isearchquaotations.com)

This book emerged from my curiosity to become acquainted with the relation between language acquisition and strategic learning. I want to share with colleagues and with student-teacher-researchers the findings after several years of work with educators. This book attempts to address the question of how to promote experiential learning and problem solving. While in formal education, pupils require to develop the capacity to do something with what is learnt, such knowledge should, among other things, allow people to understand the society in which they live in and to solve real life problems.

The gap between classroom knowledge and experiential knowledge that can be applied elsewhere has been recognized. Fragmentary knowledge is one of the causes of concern for learners and for societies. Fragmentation may be due to the fact that curricula do not clearly specify the competence (what can be done with what you know) that learners are expected to attain at the end of a cycle. In turn, fragmentation may cause interference with learning and students' discomfort with schooling (see Castillo, 2012 on the questions institutions should address). This book may equip teachers and students with ways to approach learning strategically, resulting in curricula that is less fragmented, holistic, motivating, and accessible.

"When you're prepared, you're more confident. When you have a strategy, you're more comfortable.» Fred Couples 
This book is grounded in a pedagogical context that strives for strengthening autonomous learning and for promoting thinking processes. One cannot assume that people today read less, understand less or are less able to solve problems than before. On the contrary, people have an enormous potential to learn more effectively and efficiently with information technologies, and to be more creative than previous generations (Castillo, 2012), a course of action to transform learning into useful knowledge is essential. Therefore, teaching today faces several challenges: first, focusing on process and strategies since data and information are readily available; second, preparing people to understand phenomena in a situated and contextualized form; third, forming critical thinkers able to propose innovations; fourth, making the classroom and school contexts places for autonomous learning; and fifth, preparing learners to meet the demands of a rapidly-changing society. So far efforts have focused on exploiting resources readily available for learning such as multimedia and digital objects. This book aims to push beyond exploitation of resources to help students gain autonomy and critical thinking skills, two necessary attributes nowadays.

I became interested in the subject while taking a doctoral course in Cognitive Psychology with Dr. Ellen Gagné at the University of Texas, at Austin, and draw on my experience as a teacher of Spanish and English as an L1 and an $\mathrm{L} 2$, and as a teacher educator. Recent readings and research reports were considered, as much as reflections of the author's personal experience as a reader, writer and as a parent of bilingual children. This book gives a practical interpretation of strategic learning, while providing resources to readers.

This book was written because I feel that educators ought to be informed on the nature of language, the role of language in learning, the types of knowledge involved in listening, speaking reading and writing, and the strategies that these types of knowledge call for-precisely the core of this book. This publication also hopes to be useful for teachers of all subject areas and aims at building a bridge between L1 and L2 teaching. The author is very pleased and thankful to have had this book nominated to "The Macmillan Education Award for Innovative Writing" of ELTons in the United Kingdom. (See Appendix 1).

The central thesis of this publication gives prominence to strategic learning in the school curricula. Linguistic syllabi or topic syllabi presents serious limitations to help students construct language or construct with language, even it shows difficulties to learn about the functioning of language. This 
work builds on and deepens the potential of learning strategies as initiated in my prior study (Castillo, 1991).

The concept «Strategic Learning» (also strategic knowledge) is linked with the movement of «Learning to learn» or «strategopedia», which provides a basis to enable pupils to set goals, to assume an active role, to plan their learning processes, and to take part in the evaluation of their progress. It also provides a means to enable teachers to evolve from a perspective of language as a process, to a perspective of language as cognition and, ultimately, as a sociocultural form of expression.

Every student has the potential to become successful through application of strategic knowledge (Castillo, 2004). Negotiating content, tasks and strategies would be more in line with the formation of independent, autonomous and critical learners. Strategic knowledge is important to long-term academic development. O'Malley and Chamot (1990) posited cognitive, metacognitive and cognitive strategies to tackle L2 learning. They argue that communicative competence, among other competencies, can be facilitated when pupils manage to integrate strategies to their daily practice and when they constantly draw on strategies to solve problems.

The implementation of this approach could empower teachers in making decisions about how to use language for learning. This book offers components for a school language development program, which can be finetuned to current personal purposes or to course planning. Nonetheless you must bear in mind that learning is not an isolated or individual act; rather it is a social act. Students learn with others and from others, and therefore teaching demands more than skills, techniques or strategies: it demands that teachers structure instruction for social interaction to occur and develop. Social interaction is also needed among teachers to transform curricula, course syllabi, and ultimately, the school itself.

The book's six chapters provide a rationale for incorporating strategic learning into a program, with the first chapter presenting the most influential theories behind it. The subsequent chapters address its role in reading, listening, speaking and writing. Discussion is illustrated with examples for strategy use in and outside the classroom. Implications for teaching and for syllabus design conclude each chapter. Reading and listening appear first for they constitute the input for language acquisition and they seem to develop faster than writing and speaking. 
This book has two purposes. First, it contributes to the continued education of language teachers by attempting to build a bridge between the pre-service educational practices and those that in-service teachers continually develop. Second, it encourages teachers and students to reflect on what they do about in class. You may find some ideas inspiring, some strategies novel. I encourage you to not to wait too long to try and perfect them and then, to share them with your colleagues.

It is heartening to realize that although we may crave comfort and routine, we nourish the soul's growth primarily through what is hard. As Darwin saw it, it's not the strongest of the species that survives, nor the most intelligent, but those who are most responsive to change.

Robert Cooper

The picture below, taken by the author at a museum, suggests that sometimes you must look at things from other perspectives to better understand them.

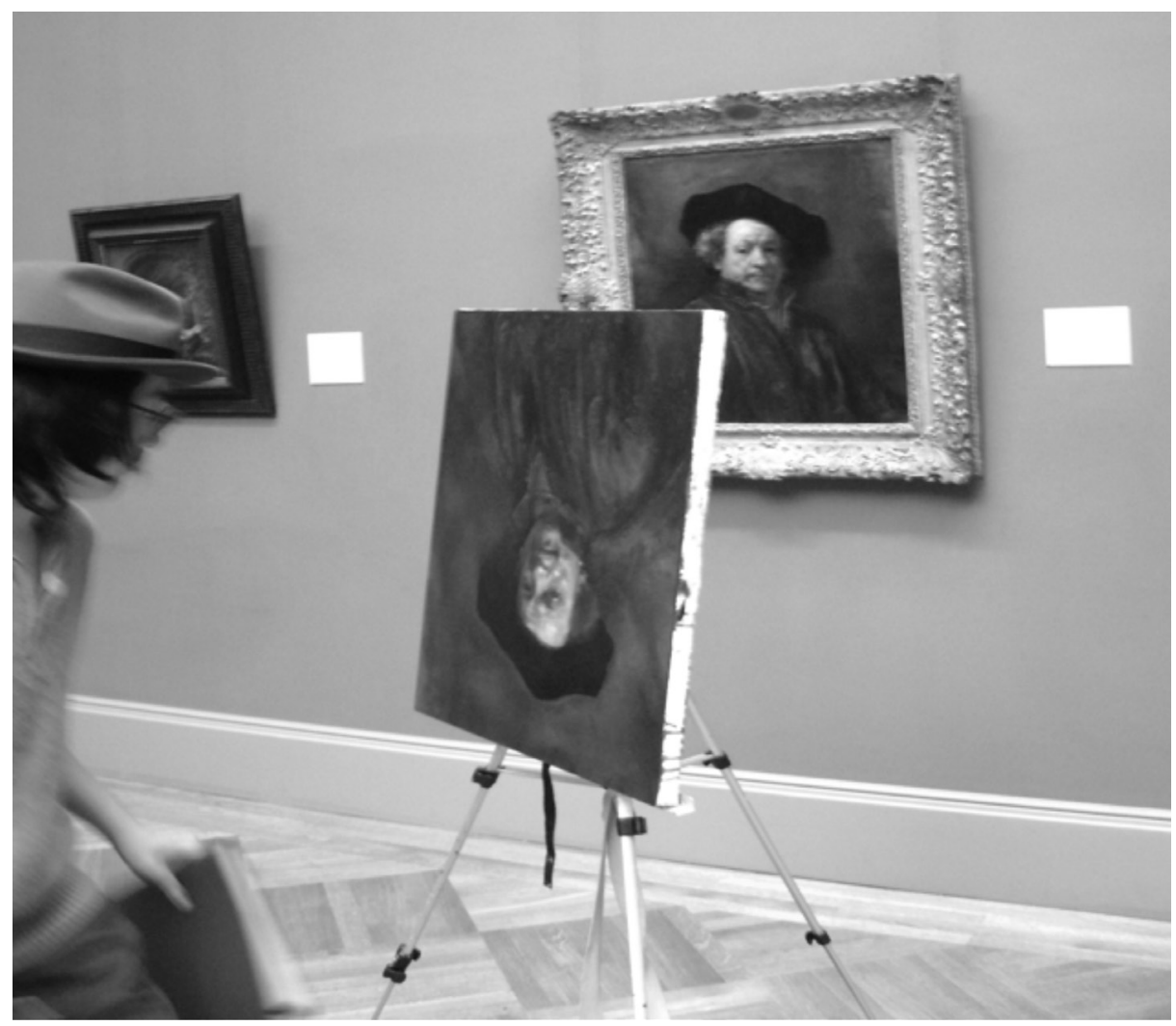




\section{Chapter I \\ Theories that illuminate Strategic Learning}

Strategy is a style of thinking, a conscious and deliberate process, an intensive implementation system, the science of insuring future success

Pete Johnson

Strategic learning has been studied extensively in first and second language (L1, L2) acquisition, and it is an issue that concerns methodology, didactics and pedagogy in general. Understanding the theories behind teaching and using learning strategies is essential for teaching, learning and assessment. The theories presented draw on the insights of strategic behaviors on listening, speaking, reading and writing. The theories will help teachers to decide how to investigate language acquisition, understand what they could do and enrich their practices. See, for instance: Oxford (2013) who offers models for conducting research on strategies.

Knowledge develops at the same time as the human being does. Similarly, a learner develops as he makes progress in education. In this scenario learners require to become aware of the strategies to succeed. Strategies may act and develop simultaneously and fluently among the participants in a community: teachers, students, and social contexts. When considering instructional design, strategies do not constitute isolated instances; they constitute a didactic choice. When considering the capacity to codify the experience of the world through language, strategies constitute cognitive and socio-cultural knowledge.

My proposed theory of strategic learning is inspired by the following fields: 1) Information Processing Theory as a foundation to understand language and thought processes; 2) The dimensions of literacy (linguistic, cognitive, sociocultural and developmental); 3) Communicative Competence; and 4) Strategic knowledge. Chapter I covers the first three. For the sake of clarity and organization, the other chapters deal with reading, writing, listening and speaking in reference to strategic knowledge and strategic learning (terms which used interchangeably here). 


\section{Information Processing Theory}

For Gagné, E. (1985, pp. 35-67) Information Processing Theory, which is cognitive in nature, estimates that knowledge is represented in a variety of forms, including propositions, productions and images. This means that in order to use or store information, humans organize knowledge through language or actions, or by representing images. Information processing theory also explains the human cognitive system as one consisting of long-term and short-term memory. Short-term memory is made of the bits of information that are being worked on (also called working memory) plus the information retrieved from long-term memory. Short-term memory processing and capacity are very limited. Long-term memory capacity is theoretically infinite. Strategies facilitate information to be received, recalled and retrieved; in other words, strategies facilitate the inclusion of information in the general cognitive system.

According to information processing theory, long-term memory consists of three types of knowledge, which also constitute all human activities:

- Declarative (factual) knowledge: our knowledge about the world, organized in schemas.

- Procedural knowledge: how to do things.

- Metacognitive: when and how to use procedures (Gagné, E., 1985, pp. 35-67).

Declarative knowledge refers to the individual that learns or knows that 'something is the case'; it is information that can be stored and retrieved upon demand. For example: «Independence day is on such date» or « $2+2=4 »$.

Procedural knowledge, on the other hand, requires steps and processes to arrive at an answer or to solve a problem. For example, for someone to answer the question: How long did the war of independence take? He/she must resort to two pieces of information, the start and end points of the war. The participant must then follow a procedure (in this case subtract) to find out the length of the war. In workshops conducted by the author, more than half of the participants failed to respond the latter question. They did not resort to the procedure of subtracting: «Independence Day was on year X... and the last battle of independence took place in year $\mathrm{Y}$, then the war of independence took $n$ years». They attempted to guess, since that information is not in their declarative knowledge. 
In the same way, "Metacognitive knowledge refers to acquired knowledge about cognitive processes, knowledge that can be used to control cognitive processes». It is held that Metacognitive knowledge helps us learn from experience how and when to use strategies. Awareness of strategy use may enhance problem-solving skills (Livingston, 1997, p. 1). One aspect of metacognition relates to being aware of how you learn, another relates to understanding the tasks, and a third, familiarity with strategies.

Information processing theory affects comprehension in the area of mental processes that can be triggered for involving and engaging pupils. For Collings (n.d.), «in order for the information to become a part of the person's world knowledge, it has to be actively processed by means of creating inferences. Inferences come from activated background knowledge». This process of making inferences can be stimulated by allowing students to relate new information to their life experiences or to other disciplines of study. For example, new knowledge is assimilated into the old schema or accommodated into a new one when someone rehearses, as Kucer (2005, p. 112) calls this aspect of information processing. For encouraging metacognition, it is recommended to propose tasks which demand inference. The assessment of those tasks can provide information on the learning path to be followed.

Pushkin (2007, p. 2) posits that if one were to view the learning process algebraically, it could be represented as the sum of thinking and knowledge. Pushkin (2007, p. 3) cites Maloney's examples in science (1994) to affirm that, in order to be a successful problem solver; four types of schema-specific knowledge are required:

- Declarative knowledge (basic arbitrary facts: e.g., $\mathrm{Na}$ is the symbol for Sodium).

- $\quad$ Procedural knowledge (algorithms: e.g., determining the velocity of a moving particle by taking the derivative of its displacement as a function of time).

- Situational knowledge (recognizing contexts in a problem: e.g., two concurrent forces are competing with each other rather than together).

- Strategic knowledge (choosing appropriate algorithms: e.g., using a Ksp expression to calculate a precipitate ion's concentration as opposed to using $\mathrm{pH}$ ).

Gagne's and Pushkin's contentions complement one another, while Maloney adds situational knowledge to stress the importance of the conditions. It is then gathered that for problem-solving, a collection of facts, 
theories, events and objects related to a subject (Declarative Knowledge) would not suffice. A set of procedures and steps for doing things (Procedural Knowledge) encourage higher order thinking, and it can also provide more connections and rehearsal for the information to be stored in long term memory. For someone to progress towards critical thinking, a combination of types of knowledge would be required. The above has implications for instructional settings that should be prepared for both, content and delivery, meaning that learners need to find reasons to attend to what is being taught. As Collings (n.d.) states:

The preparation for the information processing at schools should be a very important activity. Such preparation is closely related to the following cognitive processes:

- Connecting to prior knowledge or building it up. Prior knowledge traditionally includes historical (e.g., knowledge about an author and his time, literary theory) and modern (socio-cultural context of the modern and immediate reality) information.

- Motivation. In order for the information to be successfully stored in the long-term memory, the reader has to be genuinely interested in it. The teacher's task is to try and evoke emotional attitude of the students towards the text before reading.

Information processing theories help us understand that the content of the classroom tasks benefits from being purposeful, from showing a clear sense of direction, and from being as contextualized as possible. Pupils are not necessarily motivated by a 'surprise' topic or activity; motivation is also cognitive, that is, derived from the tasks proposed. Whereas more meaningful is the topic (that is, connected to prior information and potentially useful), is better the disposition to learn it (Castillo, 2008). Socio-cultural and historical relationships, for example, can be very motivating. In turn, motivation can evoke the interest to seek more information.

Information processing theories also highlight that when delivering the information, it is vital to show the relevance of the topic or task. The motivational aspect is closely connected with the goal of the particular situational learning activity. One of the tasks of a teacher is to help students learn to formulate goals that are most beneficial for their personal development, making motivation intrinsic and the task as personal as possible. Personal relevance also greatly contributes to a better positioning of the information in long-term memory. 


\section{The Dimensions of Literacy}

Another theory that had an influence on this book, is that of Stephen Kucer (2001, p. 5), who proposed a conceptual base for literacy with four dimensions: a) a linguistic dimension which focuses on the text; b) a cognitive dimension which focuses on mind processes; c) a socio-cultural dimension that focuses on the individual as a member of a group; and d) a developmental dimension which focuses on the growth of the individual as reader and writer.

As for the linguistic dimension, Kucer (2005) considers the functions that language serve and the various text-types used in social life. When discussing this dimension, he takes a discourse perspective rather than a language-systems perspective, that is, he discusses language as made of texts and contexts for use instead of language as a system made of parts of speech to be analyzed or understood at the word level or at the sentence level. Nonetheless, Kucer clarifies that understanding orthographic, syntactic, morphological and semantic aspects of language are essential for instruction.

As for the cognitive dimension of literacy, Kucer (2005) assigns an important role to psycholinguistic aspects like memory and perception, the nature and role of background information on reading comprehension, and cognitive interrelationships between reading and writing. The Information Processing theory relates to the cognitive dimension of literacy in which strategies are ingrained. Cohen (1996) considers that «While learners will want to know the general rubrics for strategies that they use, for them the most important thing may be to see lists of suggested strategies that are specific enough so that they are readily operationalizable» (pp. 5-6). As an example, the strategy of making connections among texts, from the same or from diverse disciplines activates background information. Naming the strategy, contrasting it with other cognitive strategies, constitutes a support to psycholinguistic aspects.

As for the sociocultural dimension, Kucer (2005) understands literacy as sets of social practices and critical responsive activities that «seek to analyze and critique issues of power and perspective that weave their way through any text and any response» (p. 170). Literacy practices involve identity, self-expression and self-representation in which pupils are given the opportunity to build a theory of the world, and later, to be able to transform it. In 
the learning of an L2 and of other cultures, it is wise to remember Mahatma Gandhi's call for open mindedness towards cultures while taking a critical stand:

I do not want my house to be walled in on all sides and my windows to be stuffed. I want the cultures of all the lands to be blown about my house as freely as possible. But I refuse to be blown off my feet by any.

As for the developmental dimension, Kucer (2005, p. 170) illustrates how children learn to «maneuver and orchestrate the various dimensions of language with diverse degree of control, flexibility on several contexts». Fluent readers and writers do not mature overnight. They can master the word when they connect it to self, to other texts, and to the world. These connections contribute to literacy development.

To complete the above discussion, I suggest taking into account the visual dimension of literacy, which I situate within the realm of information processing and consider an important aspect of strategic learning. Stokes (2002) affirms that visual literacy is the ability to interpret and generate images for communicating ideas and concepts. The author offers this example:

During a rehearsal of Debussy's La Mer, Toscanini found himself unable to describe the effect he hoped to achieve from a particular passage. After a moment's thought, he took a silk handkerchief from his pocket and tossed it high into the air. The orchestra, mesmerized, watched the slow, graceful descent of the silken square. Toscanini smiled with satisfaction as it finally settled on the floor. "There», he said: "play it like that» (Fadiman, 1985, p. 548 cited by Stokes, 2002).

The conductor Toscanini found support on an image to make his point across. Educational literature equally suggests that the use of visuals in teaching and in communicating, results in a greater degree of recollection. Instruction that incorporates varying degrees of visual components stimulates interest. The use of visual enhancements promotes the development of visual skills, in combination with the development of verbal, reading and mathematical skills. Similarly, the visual information the students bring with them to class, can serve as a means of activating background information.

Some of the strategies put forward in this book refer to several forms of graphics for instruction and enhancing understanding. Visual organizers (also called graphic organizers) that incorporate illustrations and text to depict patterns of concepts and ideas, serve as organizational frameworks to 
promote thinking and learning (Tarquin \& Walker, 1997 cited by Stokes, 2002). They can also assist in relating ideas to prior information, subordinating ideas and synthesizing data from various sources. For example, Venn diagrams may prove useful in analyzing similarities and differences between two or more concepts. It is no surprise that information technologies owe their success to the visuals, in which users find print, images and video combined.

\title{
3. Communicative Competence
}

Canale and Swain (1980) provide a theoretical framework for the consideration of Communicative Competence. In their influential paper they claim that:

\begin{abstract}
Communicative competence is composed minimally of grammatical competence, sociolinguistic competence, and communication strategies, or what we will refer to as a strategic competence. There is no strong theoretical or empirical motivation for the view that grammatical competence is any more or less crucial to successful communication than is sociolinguistic competence or strategic competence. The primary goal of a communicative approach must be to facilitate the integration of these types of knowledge for the learner, and outcome that is not likely to result from overemphasis on one form of competence over the others throughout a second language programme (p. 27).
\end{abstract}

Taking into consideration that the development of communicative competence mediates the acquisition of other types of learning, it is proposed here that the levels of communicative competence attained by an individual, seem to be directly related to the type of knowledge required. The following table depicts the levels of communicative competence.

In Table 1, reading from top to bottom, the arrows point an upward movement towards achieving communicative proficiency. Linguistic competence involves the phonological, orthographic, lexical, syntactic and semantic components, which constitute the formal components of language. It is related to declarative knowledge.

Moving up from the linguistic competence, we find Analytical Competence, involving the identification of the gist of a text, distinguishing between main and secondary ideas and understanding the rhetorical organ- 
ization. The user deals with the functional component of language that is to say, what is being communicated to whom and for what purpose. Analytical competence is related to procedural knowledge (knowing how a text is structured). Attaining analytical competence places someone at the half-way mark on the road to communicative competence. It is then argued that stopping at the intratextual level falls short of comprehension or understanding. This may occur, for example, when you limit yourself to gathering information from only one source to accomplish a task.

Table 1.Levels of communicative competence

\begin{tabular}{|c|c|c|c|c|}
\hline & Competence & Levels & $\begin{array}{c}\text { Text and task } \\
\text { types }\end{array}$ & $\begin{array}{l}\text { Type of } \\
\text { knowledge } \\
\text { required }\end{array}$ \\
\hline \multirow{3}{*}{ 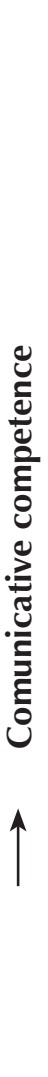 } & SOCIOCULTURAL & DISCOURSE & CRITICAL & $\begin{array}{c}\text { Critical } \\
\text { Thinking } \\
= \\
\text { Strategic } \\
\text { (implies higher } \\
\text { order thinking) } \\
+ \\
\text { Situational } \\
\text { (implies higher } \\
\text { order thinking) }\end{array}$ \\
\hline & $\begin{array}{l}\text { SOCIOLINGUISTIC } \\
\text { (Ability to interpret the } \\
\text { social meaning of the } \\
\text { choice of linguistic } \\
\text { varieties and to use } \\
\text { language with the } \\
\text { appropriate social } \\
\text { meaning for the com- } \\
\text { munication situation) }\end{array}$ & EXTRATEXTUAL & $\begin{array}{l}\text { INFERENTIAL } \\
\text { (To derive as } \\
\text { a conclusion } \\
\text { from facts or } \\
\text { premises) }\end{array}$ & \\
\hline & $\begin{array}{c}\text { Pragmatic } \\
\text { (Application of world } \\
\text { knowledge, knowl- } \\
\text { edge of linguistic } \\
\text { context and schematic } \\
\text { knowledge) }\end{array}$ & $\begin{array}{l}\text { INTERTEXTUAL } \\
\text { (Refers to the con- } \\
\text { nections readers } \\
\text { and writers make } \\
\text { among various } \\
\text { texts) }\end{array}$ & & \\
\hline
\end{tabular}




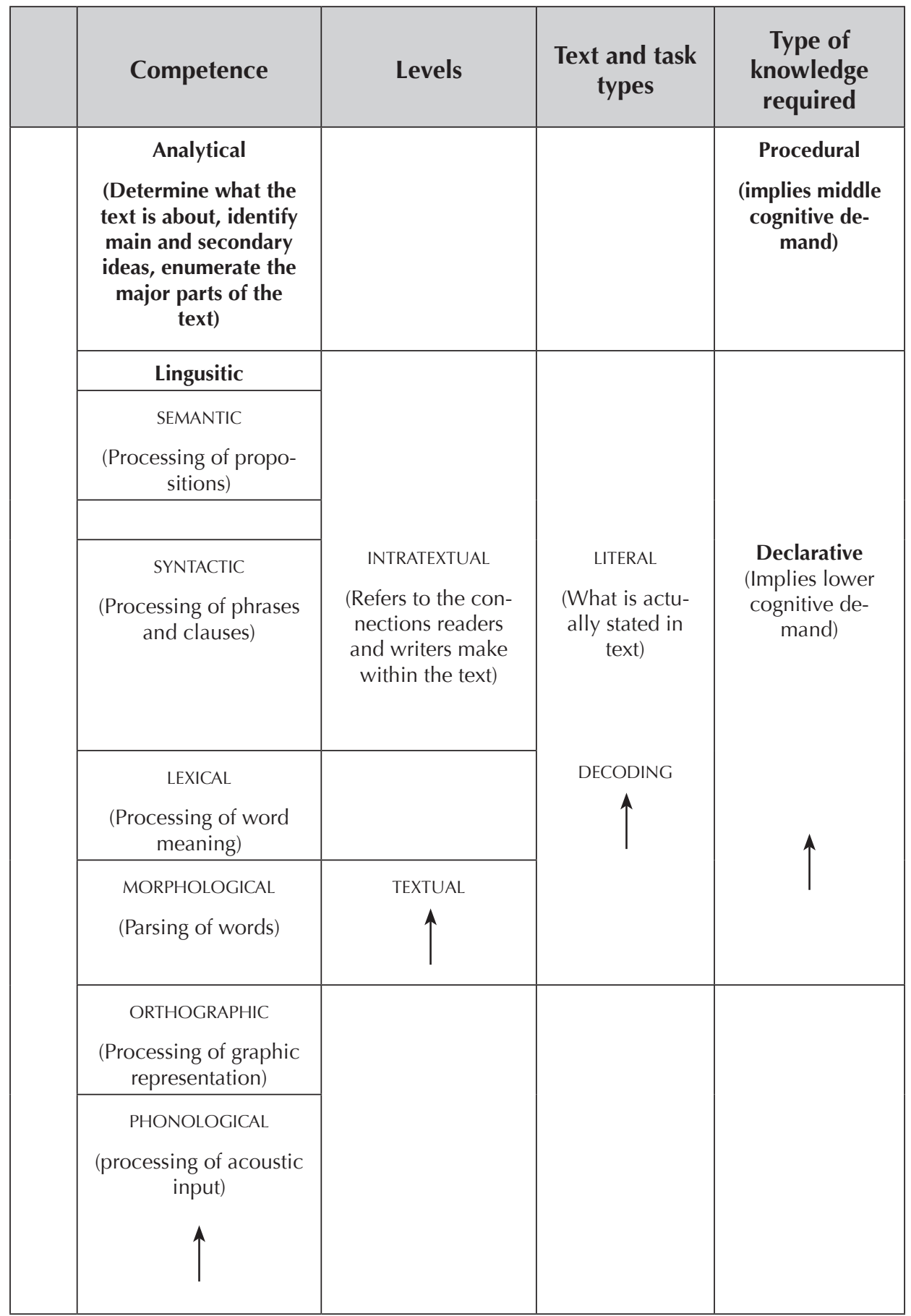

R. Castillo (2014). Adapted from Kucer (2005), Pushkin (2007) and Bachman (1990, p. 85) 
Next is Pragmatic Competence, which refers to the application of world knowledge, knowledge of linguistic context and schematic knowledge. The user resorts to the other components -from phonological competence to sociolinguistic competence- in order to process a statement.

Sociolinguistic Competence can be placed above. It refers to the ability to interpret the social meaning of the choice of linguistic varieties and to use language with the appropriate social meaning for the communication situation.

Going beyond the understanding of texts, contexts, situations in communication, Sociocultural Competence would have a prominent place. Shared and unshared cultural patterns and values influence communication and becoming sensitive to degrees of formality, or references to history and customs may facilitate or hinder access to meaning. For this competence to develop exposure to a variety of contexts and genres must be considered. The understanding of general cultural patterns may enable the user to comprehend the others' texts. Reading the word employing solely the norms of your own culture may fail to take into account situational knowledge. For L2 acquisition attempts have been made to incorporate to curricula sociocultural understanding information that would discuss some of the underlying factors that can affect discourse.

Looking at the type of knowledge required that appears in the last column of Table 1, it can be observed that critical thinking results from situational and strategic knowledge. This concurs with Pushkin (2007) that «situational knowledge plus strategic knowledge equals critical thinking, for both imply higher order thinking». Situational knowledge refers to recognizing contexts in a problem, e.g., in language what to say to whom in accordance with the status of the interlocutors, the setting, the situation and the intention of communication. On the other hand, strategic knowledge refers to choosing appropriate conventions, e.g., in language, using appropriate mechanisms to organize ideas or to synthesize them. The next chapter deals with the background, the theory and the research relevant to strategic competence.

\section{Strategic Learning: background, theory and research}

Yes, there are times when the gold medal only goes to the winner. But not in the race of life, where the winners are those who are superior not to others but to their former selves. Robert Cooper 
The theories presented here concur that there are different types of knowledge; that literacy has several dimensions; that communicative competence has several levels; and that learning is mediated by language. These theories support the notion that to learn, you require sight, sound and symbols, as well as abstraction, prediction and general thinking skills. Using language to communicate, to learn, to solve problems or to create draws on multiple dimensions: the psycho-neurological, the social and the cultural. You learn when you are able to understand, interpret, argue about or apply the meaning of a text. In other words, the act of learning consists of transferring the text meanings through the voice of the learner. It implies discovering meanings, debating and critiquing what a text says, and proposing alternative interpretations. Therefore, you may say you have learnt when you understand the intentions, when you know how to build your own idea or notion, and when you learn what works best for you to learn.

\section{Connections between communicative competence and strategic competence}

Strategic competence refers to the processes that serve as way of reaching a goal and can be conscious or unconscious. Everyone has some degree of strategic competence that may be evidenced in spite of their incomplete notions in a certain field. For example an artist, a writer or an engineer can approach a problem differently. Each would resort to the repertoire of strategies or to their diverse experiences for tackling a problem.

Strategic competence also «Refers to mastery of verbal and non-verbal communication strategies we employ during breakdown in communication or when we lack any of the competences to communicate effectively; also used to enhance the effectiveness of communication». (Wordpress, 2011. p. 1). For instance, for travelers, it is a common occurrence to resort to pointing; using a note pad or a map to make themselves understood and obtain the goal of communication. In a bilingual family, the members assign a specialized use to each language or they code switch to better get their message across. In classrooms, the students' interactions with the stimuli may serve as a basis and as a guide for understanding. Being able to apply what is known to problem-solving situations reveals strategic competence. Bachman says: 
I consider [strategic competence] more as a general ability, which enables an individual to make the most effective use of available abilities in carrying out a given task, whether that task be related to communicative language use or to non-verbal tasks such as creating a musical composition, painting, or solving mathematical equations (1990, p. 106).

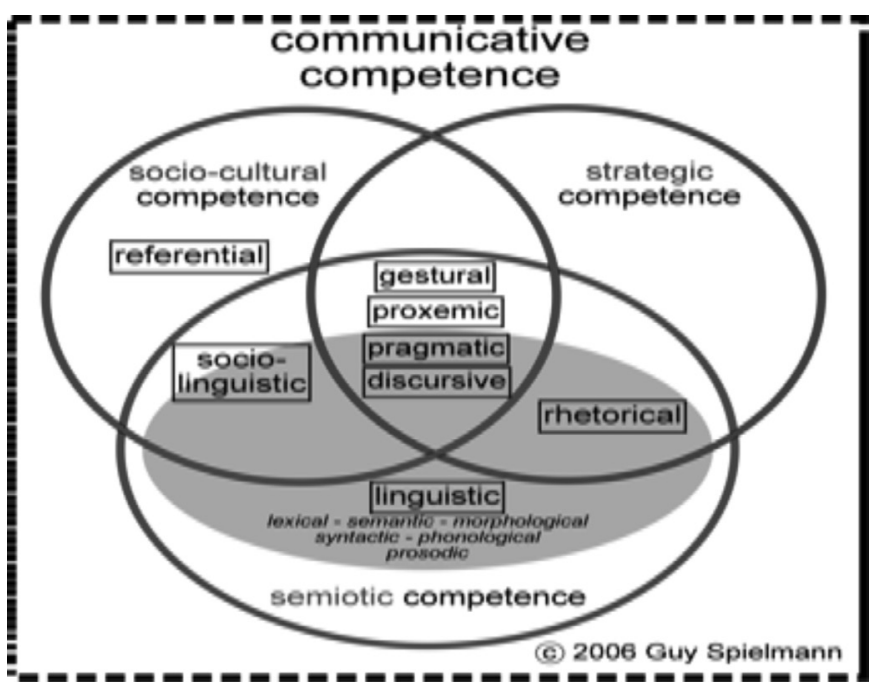

Figure 1. Components of communicative language ability in communicative language use (Bachman 1990, p. 85). Taken from Wordpress.com http://primrose33.wordpress.com/2011/11/13/communicative-competence/

When Bachman (1990, p. 85, in Skehan, 1998, p. 161) discusses a communicative competence model, strategic competence «is no longer seen as compensatory, only activated when other competences are lacking. Instead, it is central to all communication». With strategic competence, the individual determines the purpose of communication assesses the communicative resources at hand, plans and executes it. For Skehan (1998):

The most important factor, however, is that Bachman (1990, p. 85) is redefining the relationship between competence and performance, since it has now dynamic qualities. This is shown in the figure below where the central mediating role of strategic competence between knowledge structures, language structures, and context of the situation can be seen clearly (p. 161).

Figure 1 illustrates the importance of strategic competence in coordinating the contributions of other underlying competences during performance. 
Further research is needed to reveal actual processing; a case in point would be the study of the effects on performance of the application of stages like goal setting, planning, execution and assessment. Another would be finding sound evidence of the contribution of linguistic, cognitive and sociocultural factors on performance. Teacher-researchers should consider working on strategic competence and assigning it a role in their practices (see Castillo \& Diaz, 2012).

In closing, we ought to remember that strategies are goal-directed sequences of cognitive operations that lead from the student's comprehension of a question or instructions, to the answer or other requested performance (Gagné, 1985, p. 33). Within the realm of the cognitive dimension, strategies describe the psychological processes used to recall, remember and retrieve information. The literature uses several names such as technique, tactic, move or macro and microstrategies. Cohen (1996) considers that:

A solution to the problem would be to refer to all of these simply as strategies, while still acknowledging that there is a continuum from the broadest categories to the most specific or low-level. While learners will want to know the general rubrics for strategies that they use, for them the most important thing may be to see lists of suggested strategies that are specific enough so that they are readily operationalizable (pp. 5-6).

\section{The Surface Approach to Learning and the Deep Approach to Learning}

In addition to problem solving and communication, strategic learning attempts to provide answers to the question: How do you want pupils to approach the learning of a subject? How a teacher answers this question has a bearing on how the subject is taught, how assessment is carried out, and what is expected of the pupils. Along the lines of teaching, there are two related concepts that should be presented and that underlie the discussion. These terms are the surface approach to learning and the deep approach to learning. Practitioners would want their trainees to build a series of schemas that allow them to critically integrate new information to previous one. Subject-area specialists urge in their course syllabi and their teaching, that their trainees build those schemas by means of practice, by the understanding of models or by using diverse organizers. In other words, they would 
encourage a deep approach to learning in which learners would value and operate on the knowledge acquired.

As an illustration, a task in which answering to questions in an interview may bring about a surface approach to a topic. Elaboration can be better stimulated by a conversation format instead. In other words, some practices could discourage a surface approach to learning in which trainees value rote learning and in which, among other things, learners cannot distinguish between principles and examples. Another instance of practices can appear when assessing reading; for instance, exercises that require students to decode or elicit literal information from a passage, fall short of stimulating higher order thinking. The power of assessment to determine students' approaches to learning, has been recognized and assessment methods that permit or reward surface approaches can be a strong influence on how students learn.

Work in other disciplines has found a clear correlation between a deep approach and the higher levels of learning outcome. Entwhistle and Ramsden (in Lublin, 2003, p. 11) have demonstrated the significance of looking at students' approaches to learning in relation to their motive or orientation to learn. The Approaches to Study Inventory (ASI) identifies three possible orientations:

1. Meaning orientation, which correlates with a deep approach;

2. Reproducing orientation, which correlates with a surface approach;

3. Achievement or strategic orientation, in which a student will be oriented primarily towards being successful, and will therefore readily adopt whichever learning strategy is most likely to gain success.

As a consequence, teachers are able to find ways to encourage learners to understand and apply deep approaches. To do this, teachers should design and provide contexts that encourage students to be 'achievement oriented' by using deep approaches and reward their appropriate outcomes in assessment situations. On their part, Lublin J. (2003, p. 2) cites Marton and Saljo (1976); Marton, Hounsell and Entwistle (1997); Prosser and Trigwell (1998) and Biggs (1999), who argue:

What the learner does has become more important for student learning than what the teacher does. This has led to the redefinition of teaching as the facilitation of student learning. One of the outcomes of this shift has also been the redefinition of course objectives in terms of learning outcomes rather than of teaching inputs. [...] One of the major con- 
cepts to emerge from this research was the idea that students can take different approaches to learning. It is suggested that good teaching can influence students to take a deep approach, while poor teaching in the widest sense can pressure students to take a surface approach. Biggs defines good teaching as the encouragement of a deep approach to learning.

Bradford (n.d.) discusses approaches to learning and study and their implications. He cites Säljö and other researchers (such as Entwistle \& Ramsden 1983, cited by Marton, 1993) who suggest:

the need to term a third approach, that is the 'strategic' approach. This term describes students with an intention to achieve the highest grade possible through effective time management and organised study methods and an alertness of the assessment process. According to Entwistle, "Interviews with students suggest that strategic students have two distinct focuses of concern - the academic content and the demands of the assessment system» (2000, p. 3). Furthermore, whereas the identification of 'deep' and 'surface' approaches originate from research which analyzes the meaning gained from reading text, the 'strategic approach' originates from research with reference to everyday situations; therefore it more appropriately describes an approach to studying (Morgan, 1993).

Authors, like Entwistle (1987) and Biggs (1987, in Lublin, 2003, pp. 1011), also argue that the strategic or achieving approach is one which students are said to take when they wish to achieve positive outcomes in terms of obtaining a pass or better in the subject. Students taking this approach:

- Intend to obtain high grades;

- Organise their time and distribute their effort to greatest effect;

- Ensure that the conditions and materials for studying are appropriate;

- Use previous exam papers to predict questions;

- $\quad$ Are alert to cues about marking schemes.

This approach, when allied to a deep approach, would seem likely to deliver both an intelligent engagement with the subject as well as success in the subject. While the focus of interest in the literature has been on deep and surface approaches, a common view perceives strategic knowledge as how you approach studying a subject. However, as it has been discussed, strategic knowledge is concerned with how you learn in general. Nonetheless I propose that the strategic approach deals with how to solve problems 
and goes beyond academic content and study skills. The ability to transfer deep knowledge to a real life situation, as well as to a test, has to do with the understanding of principles and procedures relevant to a task or problem being undertaken.

I agree with Pushkin (2007), when he argues that classroom practices and materials may be taking away the complexity of concepts, perhaps in an effort to make learning manageable. These may be delivering a washed down version of problems and procedures that allow the application of formulas and rules, but those practices and materials may not contribute to the development of competencies and problem-solving skills. In his discussion on critical thinking and problem solving, Pushkin (2007) makes a very strong case for strategic knowledge from a cognitive perspective:

While it is relatively easy to distinguish lower-order from higher-order thinking, it is not as easy to distinguish higher-order from critical thinking. According to Lewis and Smith (1993, p. 136), "higher order thinking occurs when a person takes new information and information stored and interrelates and/or rearranges and extends this information to achieve a purpose or find possible answers in perplexing situations». While the parallel to procedural knowledge is evident, there is no explicit connection to conditional knowledge; in other words, higher-order thinking does not necessarily take the context of "perplexing situations» into account, something critical thinking does. In physics problem solving, for example, students often take mathematical equations and derive them into new expressions towards solving multi-step problems. In chemistry problem solving, students can combine their knowledge of chemical formulas, mole mass conversions, and chemical equations to solve problems that involve stoichiometry. However, the question remains as to how much opportunity students have to contextualize a chemistry or physics problem (p. 5).

The curricula needs to expand the scope of opportunities offered. This shift consists in moving away from standard textbook examples and problems to give pupils the chance to construct concepts. In other words, the content and tasks presented should expand the skills and strategies that could be utilized. In the case of language learning, teachers should offer a broader view by proposing a syllabus in which there is a textual, intratextual, extratextual and critical appraisal of the topics. A syllabus that gives the opportunity to apply language to diverse situations: world knowledge, linguistic context 
knowledge, and schematic knowledge. Such a syllabus makes connections to various texts and establishes relationships with other disciplines.

Knowledge must be built in terms of depth and breadth. Thinking needs to be more than on a linear level; it must be broad, situated, and interconnected. Learners not only need to appreciate what knowledge is, but how we use it, when and where we use it, and why we use it. Scientific literacy should mean more than mere mental possession of a volume of knowledge; possession has little value if it is not used to its fullest application (Pushkin, 2007, p. 10).

Strategic knowledge along with situational knowledge can be considered as constituents of critical thinking, a mode of cognition that is associated with problem solving (see Table 1). In new, challenging situations, critical thinkers are able to recognize unique characteristics of a problem, that dictate which concepts are specifically relevant to solving the problem. A critical thinker should be able to make decisions based on the knowledge transformed and explain the implications of the solution proposed. Our task as educators consists in creating opportunities that support the development of strategic competence.

So far this book has made reference to the dimensions of literacy in order to plan for learning, to monitor, and to evaluate texts and tasks. Chapter II brings a framework in which types of knowledge, strategic competence and reading is proposed. The same will be done later on for writing, listening and speaking. The separation in four skills was due to the necessity of organizing research findings and research-based practices. The implications for didactics, pedagogy and education appear in the last chapter. 


\title{
Chapter II \\ Strategic learning and reading competence
}

\author{
No matter how busy you may think you are, \\ you must find time for reading, \\ or surrender yourself to \\ self-chosen ignorance.
}

Atwood H. Townsend

Individuals do not develop reading competencies voluntarily; instead, they are demanded by a society that requires individuals educated in citizenship and competent to assume social and technological changes. In that sense, a reading program needs to be connected to the skills, strategies, competencies and other attributes embodied in individuals that are relevant to personal, social and economic well-being. In the proposal outlined in this chapter, reading is mediated by strategic knowledge to aid teachers promote reading processes, understand concepts, develop problem solving skills and the ability to function in various situations.

This chapter reviews the literature concerning the connection of strategic learning and reading. First, the role of the systems of language in understanding is discussed. Second, motivational, cognitive and language processes are described. Third, Bouvet's (2000) monitoring framework for advanced readers is presented. In closing, a framework for strategic reading is proposed. This framework has as pillars the types of knowledge reading calls for and the strategies that are associated with them. The framework should provide some insight into reading proficiency and serves as a guide for course designers and teachers.

Reading literacy is understood as «the capacity to understand, use and reflect on written texts, in order to achieve one's goals, to develop one's own knowledge and potential, and to participate in society» (see OECD, 2009, p. 14), whereas strategic knowledge is understood as the set of procedures students follow to approach learning. This section focuses on what readers do to recognize, organize, recall, retrieve and evaluate the information read; in other words, what they do to construct meaning. 
At this point you, the readers are invited to self-test your knowledge of teaching effective reading strategies with the worksheet in Appendix 3.

Analyzing the changes in the conceptions of reading comprehension, Dole, Duffy and Roehler (1991 in Fernandez, 2000) include strategic knowledge as a component of previous knowledge, along with the specific knowledge on the topic, general world knowledge about relationships and social structures and knowledge about the rhetorical organization of a text. Skills seem to be more connected to lower level thinking processes (like rehearsing). By contrasts, strategies are connected to higher order thinking, are more intentional, and are more flexible and more conscious.

Awareness of prior information has positive effects on comprehension, and authors, such as O'Malley and Chamot (1990), Oxford (1990, 2013), and Robb (2000), suggest the benefits of applying strategic knowledge. Their studies have shown a positive effect of overt instruction on the use of reading strategies, especially those related to generating and organizing ideas (text structuring), editing and recognizing rhetorical functions. Therefore, explicit instruction and contrastive approaches in dealing with reading comprehension strategies in classrooms have been shown to be advantageous.

Along the same lines, Pearson (1994, cited by Harvey and Goudvis, 2000) claims that «Once thought as the natural result of decoding plus oral language, reading comprehension is now viewed as a much more complex process involving knowledge, experience, thinking and teaching» (p. 6). In an effort to reveal reading processes, they conclude that understanding does not result from the study of the systems of language (orthography, syntax, morphology and semantics) nor of decoding skills and vocabulary learning, as some teaching and testing practices seem to suggest.

Other authors have looked into the processes proficient readers follow and have attempted to identify the procedures and strategies that facilitate their understanding when they read. For example, Pearson et al. (1992, cited by Harvey and Goudvis, 2000, p. 6) summarized the strategies that active thoughtful readers use when constructing meaning. They found that proficient readers:

- Search for connections between what they know and the new information they encounter in the texts they read.

- Ask questions of themselves, the authors they encounter and the texts they read.

- Draw inferences during and after reading.

- Distinguish important facts from less important ideas in a text. 
- Are adept at synthesizing information within and across texts and reading experiences.

- Repair faulty comprehension.

- Monitor the adequacy of their understanding.

- Visualize and create images using the different senses to better understand what they read (added by Keen and Zimmerman, 1997, also cited by Harvey and Goudvis, 2000, p. 7).

Recognizing the role of cognitive processes and adding motivational processes to reading proficiency, Guthrie and Wigfield (in Kamil, Mosenthal, Pearson \& Barr, 2000, p. 408) argue that «becoming an excellent, active reader involves attunement of motivational processes with cognitive and language processes in reading».

Several efforts to synthesize and explain the complexity of reading have been attempted. Bouvet (2002) studied the processes that advanced readers follow when they encounter a literary passage, and stated «In challenging reading mode, the quality of reading depends on the efficiency of problemsolving operations, including evaluative and executive strategies, put into place in order to attempt to fill in the comprehension gaps present in complex texts». Bouvet recognized several phases in the reading process and proposed a monitoring framework for reading in which previous strategic knowledge is activated. This framework, subdivided into different types of problem-solving strategies, that can be seen below (Figure 2).

Figure No. 2. Bouvet's basic monitoring framework

\section{- Evaluation phase:}

1. Problem recognition

2. Problem source identification

\section{- Action phase}

3. Strategic planning

4. Strategy implementation

- Instrumental strategies

- Deductive strategies

- Simplification strategies

- Cohesive strategies

\section{- Checking phase}

5. Check

6. Revision 
This structure suggests that advanced readers approach comprehension tasks differently from beginner readers. While reading, advanced readers evaluate the problem and make decisions and adjustments according to what emerges from the manuscript. They approach a new type of text as a problem that needs to be evaluated, a problem that needs to be addressed through some action. The action that advanced readers take, is translated into strategies used to solve a problem. For Bouvet (2000), reading proficiency relies on the ability of integrating meaning and constructing text.

One of the most pertinent features of proficient reading seemed to be the importance given to macroframe elaboration. Macroframe elaboration can occur at section, paragraph and whole text levels and is text structure dependent. This strategy consists in formulating snapshots of text at regular intervals, when the structure permits it. As reading progresses, textual pictures are touched up and updated, then put together to form a global picture.

This investigation on the strategy differences between proficient and less-proficient readers bears some implications on the teaching of reading such as the importance of helping learners elaborate macroframes. It also highlights the importance of strategic implementation being flexible so as to decide which strategies would be more appropriate and efficient for the task.

\section{A structure for strategic learning and reading}

The first tenet of Strategic Reading is that «the most fundamental task of readers is monitoring reading for making sense», (see Pearson, in Robb 2000, pp. 6-7). Checking comprehension constitutes a problem-solving operation that proficient readers conduct. In the attempt to cope and grasp meanings, proficient readers develop a plan to approach reading and to combine strategies.

The second tenet is that «teachers help their students predict and verify outcomes, create visual images from a text, locate the important stuff, synthesize information across texts and connect the text to their lives» (Pearson, in Robb 2000, pp. 6-7). 
The third tenet, developed thoroughly in this manuscript, is that reading calls for diverse types of knowledge, which are associated with specific strategies that may frequently overlap. The five types of knowledge and the strategies associated with them constitute the backbone of the proposal discussed below.

Knowledge of the content and experience calls for strategies for generating ideas. Readers relate -or can be encouraged to relate- their background knowledge and all other information at their disposal to the new information. A macroframe is identified to tackle a manuscript.

1. Procedural knowledge to organize the content calls for strategies for organizing ideas. A scheme is identified to place concepts either sequentially or hierarchically.

2. Knowledge of conventions of written discourse calls for strategies for editing ideas. Readers exercise control over the information in an attempt to condense it and verify that the pieces of the puzzle fit.

3. Procedural knowledge required to apply the other types of knowledge in comparing a written discourse calls for strategies for recognizing relevance. The recursive nature of reading requires the reader to backtrack and look for clarification and simplification of concepts.

4. Procedural knowledge required to evaluate a written discourse calls for strategies for questioning textual information (taking a critical stand).

In classrooms, an individual or a group of learners can be taught to activate a type of knowledge and to perfect the ability to apply a specific strategy. The description and details of the various strategies and behaviors, included in Table 2, represent an attempt to provide a complete and illustrated picture of strategic knowledge referred to reading.

Any book that helps a child to form a habit of reading, to make reading one of his deep and continuing needs, is good for him[/her].

Richard McKenna 


\section{Types of knowledge reading calls for and their corresponding strategies}

\section{Knowledge of the content and experience (images and concepts) call for strategies for generating ideas (identification of macroframe)}

To develop strategic reading, readers can start by building a sense of their own purpose for reading. This process happens more intuitively for proficient readers, and needs to be taught directly for less proficient readers. They must decide if they are looking for background information on a topic they know something about, or if they are looking for specific details and facts that they can use in support of an argument. Are readers trying to see how an author approaches the topic rhetorically? Knowing the purpose in reading will help readers focus their attention on relevant aspects of the passage. Metaphors evoke images and readers benefit from using those images to follow a discourse; for instance, a football field is a common metaphor to illustrate size, or a beehive to illustrate a shape or a structure.

In order to illustrate the above I'd like to share an exercise for identifying key concepts. Readers are asked to copy and paste an entire text in the tool Wordle ${ }^{\mathrm{TM}}$ (available in www.wordle.net) and obtain a graph that highlights, by frequency, the key words. For example, the graph below pictures the academic article: "High School Students' Perceptions of Evolutionary Theory" by Woods and Scharmann (at: http://wolfweb.unr.edu/homepage/crowther/ ejse/woodsetal.html). The tool serves to decodify the text and set the ground to distinguish the concepts that are central from those which are ancilliary. 


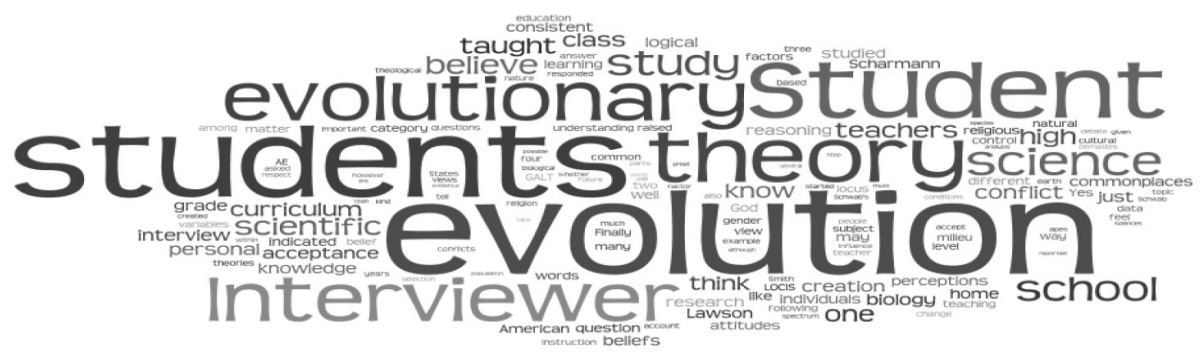

The resulting image serves to activate background knowledge, and to identify key words as a preparation for full understanding.

\subsection{Identifying the goal}

Readers benefit from identifying the goal and from deciding why they are reading the text and what they are looking for in it. They can also set a personal goal for reading. For Guthrie and Wigfield (2000), core-learning goals are co-developed by the teacher and the students in conjunction with external requirements from the school.

\subsection{Monitoring reading according to the goals identified}

The reflection on the actions and the result of reading requires cognitive and metacognitive strategies used from the start. E.g., comprehension checks must be a central part of the act of reading.

Some questions for such monitoring might include asking: Do I understand? Am I complying with the task?

\subsection{Constructing mental images}

Visualize and create images using different senses to better understand what you read. Imagine events and characters in a goal-defined context, based on prior information and on illustrations included in the text. 


\subsection{Studying tables and pictures}

Graphic representations synthesize useful information to the reader, which facilitates recalling and retrieving information.

\subsection{Making predictions based on prior knowledge}

Making judgments and predictions based on prior knowledge can help connect information stored in long-term memory with the new information that is stored in working (short-term) memory (ProTeacher.org, 2004).

\subsection{Scanning the text before reading}

Do not read from start to finish; look for specifics, especially new and unfamiliar information. Identify sections and highlight key words that relate to the goal.

\subsection{Drawing inferences during and after reading}

The reader explores the assumptions made by the writer. According to The Merriam Webster dictionary, to infer is to derive as a conclusion from facts or premises; for example, we see smoke and infer fire. The following example illustrates how a teacher, Jaime, develops his students' inference skills using poetry (ProTeacher.org, 2004):

I start out my inferring unit using poems by Douglas Florian. His short poems are about animals and I cover the animals' name, so the children have to infer what the animal is.

I THINK THAT it is a because

I do several of these poems as a whole group and then have them work through a few poems with a partner.

Text Question Schema Inference

I also do inferring of character traits and big ideas. My visual for this unit is a Venn diagram with text on one side, schema on the other and the inference being the overlapping piece. Debbie Miller has written a book that has great ideas on teaching reading comprehension. 


\section{Procedural knowledge to organize the content calls for strategies for organizing ideas}

The manipulation of information helps recalling and retrieving information. The identification of a scheme encourages inference, guessing from context, and decisions on what to look for outside the text or to seek assistance.

\subsection{Self-questioning}

Ask questions before, during and after reading, and look for the answers in the text. Ask questions of yourself, the authors you encounter and the texts you read. For example: Have I read something like this? How does this topic connect to other class topics?

\subsection{Making a decision when to read through a text without stopping}

Fluent reading will be aided by making the right decision of when to go through a text without stopping and when to backtrack and check what is being asked.

\subsection{Making guesses}

Based on background knowledge, on linguistic context and on any other cues, the reader hypothesizes the meanings of parts of the text.

\subsection{Looking up the word in the dictionary}

An efficient use of the dictionary is a desirable sub-skill for readers. Familiarization with on-line dictionaries is most desirable.

\subsection{Being an autonomous learner}

Readers attempt to approach tasks as problems and try to solve them alone; they distinguish what can be done alone and what requires the assistance of others.

\subsection{Seeking for clarification when confused}

Readers resort to the teacher or to someone else to check understanding. 
3. Knowledge of written discourse conventions call for editing strategies. The control and verification of understanding runs through the revision for coherence

\subsection{Summarizing}

Make note of the key ideas in your head as you read, or write them down. Paraphrase what is central to the topic and to the task.

\subsection{Distinguishing more important facts/ideas from less important ones} in text

Relate the topic and the purpose of the text to decide what is central and what is subsidiary. Work on the identification of topic sentences in a paragraph. Identify the supporting ideas.

\subsection{Looking for the main idea in the text}

Ask: What is this text about? What the writer wants to tell us, might help the identification of the main idea.

\subsection{Monitoring the adequacy of your understanding}

To become a fluent reader, it is necessary to develop metacognition, i.e., being able to reflect and exercise control over understanding.

\subsection{Integrating the parts to a whole in order to make sense of the text}

Same as above, metacognitive strategies are developed to look for the connections between a part of the text and the full text.

\subsection{Connecting the text to prior knowledge based on your goal}

Do not take for granted that background information is automatically activated. Readers ought to remember why they are reading and how the text relates to what they already know. When reading in an $\mathrm{L} 2$, readers can call on L1 background for transfer. I have found useful to ask readers to relate the topic under study to movies and television shows they have watched. This has proved to encouge larger participation. 


\subsection{Becoming adept at synthesizing information within and across texts and reading experiences}

The power of synthesis comes with making intertextual relationships. Synthesis can be compared to baking a cake: the ingredients would be the parts of language required to cope with the task of comprehending; the preparation of a cake would be the steps, procedures and monitoring of the process, that is, the strategic knowledge applied; and the synthesis would be the cake itself.

For example the REAP, which stands for Read, Encode, Annotate, Ponder strategy. REAP encourages literal comprehension and editing of ideas. As an example and activity proposed by Lambton Kent District School Board (2008):

Objective: Demonstrate understanding of a text by summarizing the important ideas in a text and citing details:

a. Introduce the activity: What do good readers do when they want to summarize something they've read?

b. Implement the activity. Use the graphic organizer: in a table of 2 by

2, insert the letters $R, E, A$ and $P$ in each square:

R- Read on your own. Jot down the title and author.

E- Encode the text by putting the gist -main idea- of what you read in your own words

A- Annotate the text by writing down the main ideas (notes, significant words, quotes) and the author's message.

P- Ponder what you read by thinking and talking with others in order to make personal connections, develop questions about the topic and/or connect this reading to other reading you have done.

c. Reflect on the activity: How did the four steps in the boxes help you summarize the text? Compare your REAP with a partner. Circle things that are similar. Discuss with your partner. Join another group and repeat.

d. Apply the activity. Give an appreciation statement to your partner. 
OISE (2013) acknowledges that:

Research has shown REAP to be highly successful and useful. Eanet and Manzo (1976) praise REAP as a strategy which will ensure meaningful reading and encourage concise writing and thinking. REAP is also a technique for imprinting information in long term memory ( $p .1)$.

\section{Procedural knowledge required to apply the other types of knowledge in comparing a written discourse call for strategies for recognizing relevance (clarification and simplification)}

\subsection{Cognitive and effective interpreting}

Construct alternative interpretations of the text. For instance, the reader compares coherence of his first attempts to understand with further attempts. Faulty comprehension is repaired.

\subsection{Choosing the interpretation that fits in your existing world knowledge}

Compare what you read with previous notions you had on the topic.

\subsection{Reflecting on the reading in oral or written form}

Read taking notes or discussing the content of the passages.

\subsection{Deciding on the personal value the text has for you}

Ask yourself: What did I learn? How does it relate to my goals?

Readers must develop criteria and decide on the merit of the text. As the British historian G. M. Trevelyan sentenced: «Education... has produced a vast population able to read, but unable to distinguish what is worth reading, an easy prey to sensations and cheap appeals» (Eagle Express, 2012, p. 1).

4.5 Coding a text to verify the consistency of understanding. Sharrio, C. (2009) proposes that: 
Teaching students to code text is one way to scaffold metacognition. A think-aloud format works well for this. Some coding suggestions which have worked with students are:

\begin{tabular}{|c|l|}
\hline$?$ & I have a question about this part. \\
\hline$*$ & This is an important part because... \\
\hline+ & This connects/relates to me because... \\
\hline !! & This part is interesting to me because... \\
\hline
\end{tabular}

It is important that the symbols be easy to draw and make sense to the students. You may want to let students create their own symbols and descriptors for coding text. For example, you might have students write when they have consciously connected to the reading and what types of connection they used. One group of students called parts that didn't make sense "hot spots." They would use post-it notes on the hot spots and when they met in guided reading groups or literature circles they would discuss these hot spots. (lesson 8).

\section{Procedural knowledge required to evaluate a written discourse calls for strategies for questioning textual information (taking a critical stand)}

Once you understand what is being presented, you may be ready to evaluate. As you re-read, it is helpful to jot down notes concerning the content; indicate the sections with which you agree/disagree, question the puzzling sections and mark the sections that seem contradictory or irrelevant.

It is nearly impossible to critically analyze everything about a piece of writing (unless it is extremely short). Attempting to do so often leads you into unsupported generalizations rather than a detailed criticism of the work. Your analysis should focus on the following:

5.1 Analyzing and critiquing issues of power and perspective that weave their way through any text and any response (Kucer, 2005, p. 242). Readers should ask questions like the ones in 5.1.1; 5.1.2 and 5.1.3. 
5.1.1 Authority. Does the article [or text] come from a reputable source? What authority does the author have on the subject? Sources like scientific and academic journals or books from established publishers should be preferred to popular literature, especially in the academic world.

5.1.2. Focus. Does the article present facts or only opinion? If the author offers opinions, are they well-supported? Are they too generalized? The reader needs to determine if the information presented is relevant and sufficient.

5.1.3 Thesis Statement: Is it convincing? Is it logical? Do you agree/disagree with it? Why? The reader would need to compare with other authors (see also Writing Center: Youngstown State University).

5.2 Recognizing the author's purpose involves inferring a basis for choices of content and speech. For example, a chronological explanation may provide a representation providing context or may misrepresent and show bias, answering questions like these gives insights into the choices made by the author.

Organization

How does it function in the text?

Is the text well-organized?

How does the author use transition devices?

5.3 Recognizing tone and persuasive elements involves classifying the nature of language choices. The tone may make a difference in interpretation. The reader, for instance, needs to judge the relevance of examples.

Supporting Details- Do they logically support the thesis?

Is support of the thesis complete?

Do you agree/disagree?

Why? Are irrelevant or pointless details included?

Are you persuaded? Why (not)? 
5.4 Recognizing the author's position vis-à-vis the issues involves classifying the nature of patterns of choice of content and language.

Analysis of the Issues- Are they examined completely?

Does the author cover all possible angles?

Does the author leave important things unsaid?

What bias can be evidenced?

The questions above call for diverse types of knowledge. These questions aim at triggering responses that require a deep approach to learning, discussed in chapter I. Analysis and critique demand a full understanding of the issues. The argumentation becomes more solid when a range of responses to such questions are entertained or considered.

Table No. 2. Types of knowledge reading calls for and the strategies that go with them

\begin{tabular}{|l|l|}
\hline $\begin{array}{l}\text { TYPES OF } \\
\text { KNOWLEDGE }\end{array}$ & \multicolumn{1}{|c|}{ STRATEGIES } \\
\hline $\begin{array}{l}\text { Strategies for recognizing ideas (identification of macro- } \\
\text { frame) } \\
\text { Identifying the goal } \\
\text { Why am I reading? Do I understand? } \\
\begin{array}{l}\text { 1. Knowledge } \\
\text { of the content } \\
\text { and experience } \\
\text { (images and } \\
\text { concepts) }\end{array}\end{array}$ & $\begin{array}{l}\text { Constructing mental images } \\
\text { Imagine the events and characters in goal-defined context } \\
\text { based on the prior knowledge and illustration included in the } \\
\text { text. } \\
\text { Making predictions based on prior knowledge } \\
\text { Scan the text before reading; Draw inferences during and after } \\
\text { reading. } \\
\text { Seeking for clarification when confused (meta-cognitive skill). }\end{array}$ \\
\hline
\end{tabular}




\begin{tabular}{|c|c|}
\hline $\begin{array}{l}\text { TYPES OF } \\
\text { KNOWLEDGE }\end{array}$ & STRATEGIES \\
\hline $\begin{array}{l}\text { 2. Procedural } \\
\text { knowledge to } \\
\text { organize the } \\
\text { content }\end{array}$ & $\begin{array}{l}\text { Strategies for organizing ideas (identification of schema) } \\
\text { Self-Questioning: Ask yourself questions before, during and af- } \\
\text { ter reading, and look for the answers in the text; Ask questions } \\
\text { of yourself, the authors you encounter and the texts you read. } \\
\text { Re-read; skip for now, look for the answers as you read; Make } \\
\text { guesses; Look up the word in the dictionary; Try to figure it out } \\
\text { on your own, without asking a knowledgeable other. } \\
\text { Organization. How does it function in text? Is the text well- } \\
\text { organized? How does the author use transition devices? }\end{array}$ \\
\hline $\begin{array}{l}\text { 3. Knowledge of } \\
\text { conventions of } \\
\text { written dis- } \\
\text { course }\end{array}$ & $\begin{array}{l}\text { Strategies for editing ideas (control and verification) } \\
\text { Summarizing } \\
\text { Hold the key ideas in your head as you read (make notes); } \\
\text { Distinguish important facts from less important ideas in text. } \\
\text { Look for a big idea in the text. } \\
\text { Vary the reading speed. } \\
\text { Monitor the adequacy of your understanding. } \\
\text { Integrate parts into the whole in order for it to make sense; } \\
\text { Become adept at synthesizing information within and across } \\
\text { texts and reading experiences. } \\
\text { Connect the text to prior knowledge based on your goal. }\end{array}$ \\
\hline $\begin{array}{l}\text { 4. Procedural } \\
\text { knowledge re- } \\
\text { quired to apply } \\
\text { the other types } \\
\text { of knowledge } \\
\text { in comparing a } \\
\text { written dis- } \\
\text { course }\end{array}$ & $\begin{array}{l}\text { Strategies for recognizing relevance of ideas (clarification and } \\
\text { simplification) } \\
\text { Cognitive and affective interpreting } \\
\text { Identify the support for the thesis (examples, illustrations, argu- } \\
\text { ments, etc.). } \\
\text { Construct alternative interpretations of the text; Repair faulty } \\
\text { comprehension. } \\
\text { Choose the interpretation that fits in your existing world } \\
\text { knowledge; Reflect on the reading in oral or written form; } \\
\text { Decide on the personal value the text has for you. }\end{array}$ \\
\hline
\end{tabular}




\begin{tabular}{|l|l|}
\hline $\begin{array}{l}\text { TYPES OF } \\
\text { KNOWLEDGE }\end{array}$ & STRATEGIES \\
\hline $\begin{array}{l}\text { Strategies for questioning textual information (taking a critic- } \\
\text { al stand) }\end{array}$ \\
$\begin{array}{l}\text { 5. Procedural } \\
\text { knowledge } \\
\text { required to } \\
\text { evaluate a } \\
\text { written dis- } \\
\text { course }\end{array}$ & $\begin{array}{l}\text { weave their way through any text and any response (c.f., Kucer } \\
\text { Recognizing the author's purpose involves inferring a basis for } \\
\text { choices of content and language. } \\
\text { Recognizing tone and persuasive elements involves classifying } \\
\text { the nature of language choices. } \\
\text { Recognizing bias involves classifying the nature of patterns of } \\
\text { choice of content and language. }\end{array}$ \\
\hline
\end{tabular}

Castillo (2014). Adapted from: O'Malley and Valdez (1996); M. Pressley, as cited by Collings (2007); Keen and Zimmerman (1997) and Pearson, 1992 (in Harvey \& Goudvis, 2000, pp. 6-7); Kucer (2005), McDonough (1995, p. 57, cited by Fernández (2006), Guthrie and Wigfield (2000).

\section{Discussion}

Teachers can observe some of the strategies presented in this section; others need to be drawn out of the learners through surveys, elicitation or read-aloud procedures. Other strategies may be absent and they need to be presented, given a name and practiced in class. These strategies are adaptable. They can be presented before, during, or after reading, as the learners' needs arise. The strategies need to be taught overtly; they have to be applied consciously, and their use needs to be assessed -refer to Appendix 2 as an example-. In addition, a good reading program depends upon the creation of an environment that continually portrays the value and usefulness of reading (Pearson 1990) and I add, the value and usefulness of the strategies to read.

Reading as an interactive endeavor is closely connected to thinking. Integrating strategic knowledge to a reading program would enable all readers to make sense of the world through reading, in order to meet the challenges of today's societies. 
There are vital aspects for effectively teaching reading. The first is that teaching needs to stress the study of the systems of language as a dynamic body, that each system is logical and functions to serve communication. The study of language has the clear purpose of contributing to understanding. The second is that teaching must motivate learners. The texts and tasks proposed must be intrinsically motivating and challenging. Teachers sharing their personal reflections and experiences with their learners as they go through a passage, can motivate and engage them into a deeper approach to learning, one in which comprehension is central. Last, teachers gain cognitive insight by identifying the processes, procedures and strategies that they use and share them with their learners, so as to better understand and construct the relationship between teaching and learning. In order to facilitate motivational and cognitive processes, readers require opportunities to read in and outside the classroom. They need access to a large supply and variety of books, texts and media, and with resources of time available to them to read.

Teachers are encouraged to observe and inquire about reading processes. A challenge ahead consists of investigating how learners combine or may combine strategies as proposed by McDonough (2006, pp. 69-70). Another is to identify the context and the sequence in which strategies should be included. The macroframework here proposed could serve to outline a reading program and provide foundations for a reading approach at which strategies become central.

No one can read with profit that which he cannot learn to read with pleasure Noah Porter 


\section{Chapter III Strategic learning and listening competence}

The art of conversation consists as much in listening politely, as in talking agreeably.

Atwell

This chapter deals with the nature of listening, the components underlying listening proficiency, strategic listening and variables involved in listening comprehension, such as word-level, sentence-level, discourse-level and task processing factors. The relationship between reading, discussed in the previous chapter, and listening is very close, except for the fact that in ordinary situations the reader has more control over the input than the listener.

Brown and Yule (1993, p. 332) studied the social interaction reflected in conversation and the nature of the process of oral comprehension. They conclude, among other things, that a new perception of how speech functions, is in order and it is necessary to rethink the nature of discourse as a complex cognitive and social phenomenon. At a time in which most discussion has been devoted to the development of literacy (reading and writing), developing oracy (listening and speaking competence) in the first and the second language has become of the utmost importance. Until recently, oracy seemed to be taken for granted since the children already listened to and spoke their first language upon arrival in school. Understanding spoken messages at the right level and expressing themselves according to the communicative situation, are central to the development of learning; failure to understand hinders comprehension and social interaction and ultimately becomes an obstacle to learning.

In discussions of the Communicative Approach, Canale and Swain (2002) speak of communicative competence in terms of three components: a) grammatical competence: words and rules; b) sociolinguistic competence: appropriateness; c) strategic competence: appropriate use of communication strategies, and d) discourse competence: cohesion and coherence. Scarcella and Oxford (1992, pp. 140-42) applied this model to listening comprehen- 
sion. Strategic competence, to some extent, is connected to readiness and problem solving skills for listening, while grammatical competence relates to identifying tense and aspect in the utterances heard. As for sociolinguistic competence, the listeners possess contextual information that allows them to interpret messages. Similarly, discourse competence allows the listener to discard unlikely interpretations.

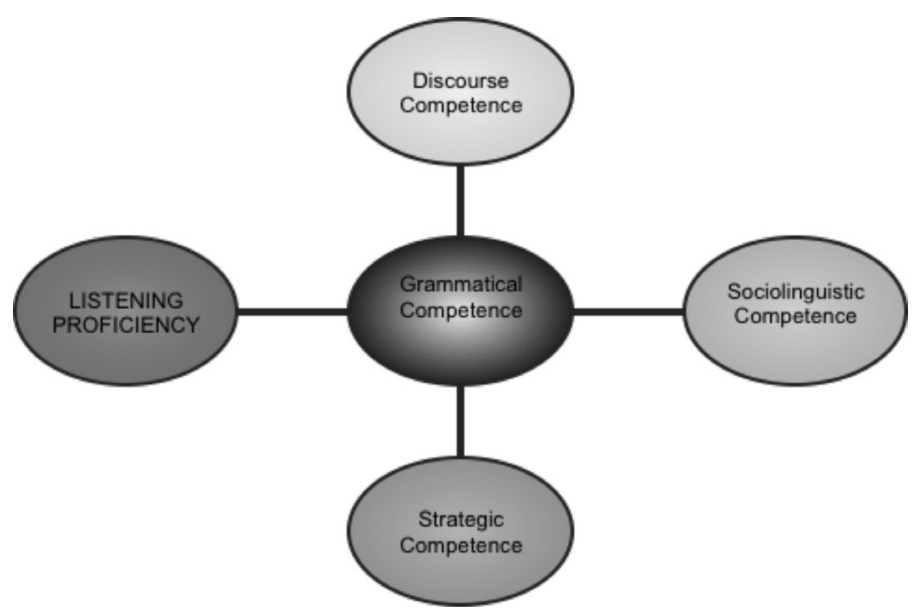

Figure 3: The components underlying Listening Proficiency. Scarcella and Oxford (1992, p. 141).

Strategic Competence refers to using any and all clues for figuring out the meaning such as knowledge of the world, knowledge of the word or linguistic cues. Guessing, for instance, plays an essential role in hypothesis testing and comprehension monitoring; the hypothesis is proved or disproved. Listeners have to predict what is coming next, in the same way a dancer anticipates the next beat of an unknown piece. The use of linguistic cues, such as cognates, affixes and deictic expressions (those that refer to someone like «sir, honey, hey you») give the learner a clue to the meaning. Paralinguistic features, such as pitch and tone, also supply useful information to the listener as do non-linguistic cues like gestures, gaze, posture or proxemics.

Grammatical Competence, on the other hand, refers to understanding and applying the rules of morphology and syntax to understand what is heard or read as in the case of tenses. Bourke (2008) proposes helping learners become aware of grammar functioning within the realm of authentic texts. The exposure to authentic spoken language helps learners to construct their own grammar. For example, exposure to Portuguese helps a listener build a 
morphological rule: word formation with ion as in the words meditation attention, intention and intuition, appear in Portuguese as «ção»: meditação, atenção, intenção, intuição. Ellis (1995) proposes noticing as a pedagogical strategy to develop grammatical competence. Teachers and learners highlight the specific features of the language in use; in the case of the example, teaching highlights word derivation from verb into a noun.

Sociolinguistic Competence refers to knowing social and cultural expectations related to the adequacy of language use and using these expectations as a basis for understanding what is heard.

Discourse Competence refers to knowing how discourse operates on coherence and cohesion, so as to recognize or understand what is heard in short or extended discourse above the sentence level. When listeners activate a macroframe such a genre (e.g., newscast, interview, ad), they can grasp the message for they can anticipate the sequence.

Bakhtin uses the term utterance in a very particular way: although spoken by a single person (or in the case of a written utterance, an author or group of coauthors) an utterance can be viewed as a link in a dialogic chain. A given utterance does not stand by itself, but is inseparably linked to other utterances: the already spoken utterances of the past, the already spoken utterances that immediately precede it in a given conversation, the anticipated utterances that will follow from fellow speakers or writers in the conversation, and the anticipated responses that will follow from generalized others (Montgomery, $B$. M. \& Baxter, L., 2013, p. 3).

Listeners deal with messages that bring a lot of information that have to be sorted out, such as intention of the speaker(s), purpose of the interaction, facts and emotions expressed or involved. This information needs to be parsed and assessed to process an adequate and appropriate response that corresponds or approximates the listener(s) own intentions, purposes, emotions and tact.

In a study on the listening section of the international test of English as a foreign language TOEFL, Kostin (2004) provides interesting insights on these variables in listening comprehension: word-level factors, sentence-level factors, discourse-level factors and task processing factors, which are presented below. 


\section{Word-level factors}

Past research has shown that the meaning of an unfamiliar word can often be inferred from the linguistic context in which it is embedded (Miller, 1999, cited by Kostin, 2004). However, sparse linguistic context in dialogues or short passages makes it difficult to infer the meaning of an unknown word from context, so one might expect that familiarization with vocabulary will have a significant effect on the difficulty of dialogues or passages. Therefore, it is safe to assume that the more background information and linguistic, and situational context, provided the better the chances are to infer lexical items and to favor comprehension. When local spaces, elements and situations are used as input comprehension, is enhanced. C.f., Pratt (2006); Castillo and Vargas (2013b).

Further, Kostin (2004) argues that phonological variables also may affect item difficulty. Henrichson (1984, cited by Kostin, 2004) reported that the difference in listening comprehension between native speakers of English and nonnative speakers was greater when they listened to spoken English employing colloquial variation. Sandhi-variation refers to «the phonological modification of grammatical forms which have been juxtaposed» (Crystal, 1980, p. 311, cited by Kostin, 2004). Examples of sandhi variation are gonna for going to, wanna for want to and hasta for has to. This finding supports the hypothesis that sandhi-variation makes comprehension of speech more difficult for nonnative speakers of English. Exposure and awareness of the existence of these forms may aid the learners' understanding of what is said.

\section{Sentence-level factors}

Listening comprehension is affected by syntactic complexity. Kostin (2004) cites Anderson \& Lynch (1988) and Rost (1990) to contend that the more complex the syntax is in a text or utterance, the more difficult it is to comprehend. Nissan et al. (1996, in Kostin, 2004) also support that: a) the presence of more than a single negative in TOEFL dialogues was positively associated with item difficulty. In a related finding, Freedle and Kostin (1999) reported that: b) the number of negatives present in TOEFL mini-talk passages 
was positively related to item difficulty. Negative statements demand more on the listener. Consistent with findings on complexity, Buck and Kostin (1999a, in Kostin, 2004) established that the presence of within-text referentials in test dialogues was positively related to item difficulty. The use of pronouns instead of nouns proves to make the spoken text harder to follow.

\section{Discourse-level factors}

Comprehension of spoken texts depends on the familiarity with the topic. Nissan et al. 1996 (in Kostin, 2004) reported on the relationship between discourse characteristics of the text and item difficulty. They found that the utterance pattern in TOEFL dialogues was significantly related to item difficulty: for TOEFL dialogues composed of two utterances, they found that items associated with dialogues having a statement in the second utterance were significantly more difficult than items associated with dialogues having a question in the second utterance.

Several researchers have studied the effects that different kinds of redundancy in a text have on listening comprehension. For L2 listeners, at lower and intermediate levels of ability, redundancy in a text in the form of repeated nouns seems to be more effective in facilitating listening comprehension than other restatement devices, such as synonyms (Chaudron, 1995 in Kostin, 2004). On the other hand, in a study by Chiang and Dunkel (1992, in Kostin, 2004), elaboration of information, repeating segments of the text or paraphrasing information, only facilitated the comprehension of high listening-proficient L2 test takers. According to Chiang and Dunkel, the lack of adequate vocabulary prevented the lower-level test takers from taking advantage of the kinds of redundant information used in their study.

Educational plays illustrate how discourse-level factors can be used to the advantage of learners. When you take students to a play, visual elements accompany the narrative, when there is redundancy and a rich context understanding is enhanced. In Castillo (2011), educational plays for language education are discussed. The same can be said when listening to television shows in an L2. 


\section{Task-processing factors}

Other factors that influence listening comprehension deal with task-processing which typically involve an interaction between features of the text and features of the item. One task-processing factor that has been found to influence listening item difficulty is whether or not an item requires the listener to infer beyond what is explicitly stated in the text. Nissan et al. (1996, in Kostin, 2004) reported that TOEFL dialogue items that required an inference (i.e., items that tested implicit information) were significantly more difficult than items that tested comprehension of explicit information.

Listening difficulty can be affected by lexical overlap between words in the text and words in an item's options. Freedle and Fellbaum (1987, in Kostin, 2004) found that the greater the amount of lexical overlap between words in the correct option and words in a single stimulus sentence (an item type in the TOEFL Listening Section prior to 1995), the easier the item. In their pilot study of the test of English for International Communication, TOEIC dialogue items, Buck and Kostin (1999a) similarly found that easier items were characterized by a greater amount of lexical overlap between words in the dialogue and words in the correct option. They further found that if there was a greater degree of lexical overlap between words in the dialogue and words in the incorrect options as compared to the correct option, the item tended to be more difficult.

Studies in the field of reading comprehension have found that information from the most recent clause in a sentence is more accessible than information from an earlier clause (Gernsbacher, 1990, in Kostin, 2004). One possible implication in regard to listening stimuli, such as dialogues, is that the last clause of a dialogue is the one best retained in short-term memory. Consistent with this, Buck and Kostin (1999a, in Kostin, 2004) reported that when the information directly relevant to responding correctly to an item came at the end of a TOEIC dialogue, frequently coinciding with the last clause, the item tended to be easy. Furthermore, if there was lexical overlap between a word in the correct option and a word that came at the end of a TOEIC dialogue, the item also tended to be easy.

Kostin (2004) warns that at present, these findings are suitable primarily for hypotheses generation, since they still need to be replicated. However, 
it is appropriate to note that several of these variables did not come simply from an examination of the items themselves, but also from a survey of the research literature. The direction with which these variables correlated with item difficulty is, in all cases, consistent with the findings in the research literature. This provides evidence to suggest that the results regarding some of these variables will be successfully replicated.

In the literature of L2, there are many references to comprehensible input as a desired feature of classroom instruction (Nunan, 1999), yet Vahle (2006) states that learners can be trained to be more comfortable with incomprehensible input. This author argues that a learner who cannot [fully] comprehend a text or a message, may in fact be acquiring something like to 'catch a thread' and occasionally words or phrases, imitate intonation, periodically repeating phrases and writing down what is heard. Learners shall become aware that by using diverse contextual clues, they may figure out the gist of a message. This argument resembles $L 1$ acquisition processes, in which children are exposed to a lot more input than they can follow; this exposure enriches rather than hinders language development.

Looking at a larger perspective, it is worth presenting a view of Strategic Listening referred to effective communication.

Witt (n.d.), a coach who works with executives and technical experts, presents listening as a problem solving activity. When discussing Strategic Listening he asserts that:

We can communicate on one-or all-of four different levels at any given time: 1. Facts; 2. Meaning; 3. Feelings, and 4. Intention. "The house is burning» is a simple, straight-forward statement. But those four words -depending on how they are said- may mean: a) "A residential structure is being consumed by flames» (Facts), b) "The house we're in is on fire» (Meaning), c) "Ahhhh!!!!» (Feelings), d). "Run for your life» (Intention). Sometimes we don't understand other people, because we're not listening -or not listening well-. We're distracted or simply not paying attention. But sometimes we don't understand them, because we're not hearing what they want to communicate. We're not listening to the right level. Strategic listening allows you to hear the various messages people are communicating. 
Table No. 3. Witt's Levels of Strategic Listening

Level 1 The Facts

\begin{tabular}{|l|l|}
\hline People want to & Convey information. \\
\hline Our task is to & Listen for details and clarify. \\
\hline We need to ask & «Who? What? Where? When? Why? How?» \\
\hline Our goal is to & $\begin{array}{l}\text { Picture the situation as the person is describing } \\
\text { it. }\end{array}$ \\
\hline
\end{tabular}

Level 2 Meaning

\begin{tabular}{|l|l|}
\hline People want to & Make themselves understood. \\
\hline Our task is to & $\begin{array}{l}\text { Listen for the big picture; summarize and para- } \\
\text { phrase. }\end{array}$ \\
\hline We need to ask & $\begin{array}{l}\text { «Am I understanding you correctly?» } \\
\text { «Is this what you're getting at?» }\end{array}$ \\
\hline Our goal is to & $\begin{array}{l}\text { Understand what the person means -and make } \\
\text { the other person feel understood-. }\end{array}$ \\
\hline
\end{tabular}

Level 3 Feelings

\begin{tabular}{|l|l|}
\hline People want to & Connect on an emotional level. \\
\hline Our task is to & $\begin{array}{l}\text { Listen with empathy; pay attention to body lan- } \\
\text { guage and tone of voice. }\end{array}$ \\
\hline We need to ask & $\begin{array}{l}\text { «How does this make you feel?» } \\
\text { «lt sounds to me like you're feeling...» }\end{array}$ \\
\hline Our goal is to & $\begin{array}{l}\text { Recognize how the person is feeling -and make } \\
\text { the other person feel connected-. }\end{array}$ \\
\hline
\end{tabular}

Level 4 Intention

\begin{tabular}{|l|l|}
\hline People want to & Get their needs met. \\
\hline Our task is to & $\begin{array}{l}\text { Listen for wants and needs; focus on solutions, } \\
\text { action steps, and outcomes. }\end{array}$ \\
\hline We need to ask & $\begin{array}{l}\text { «What do you want to have happen?» } \\
\text { «What would help you in this situation?» } \\
\text { «What can you/we do about it?» }\end{array}$ \\
\hline Our goal is to & Know what the person wants to achieve. \\
\hline
\end{tabular}

Chris Witt (n.d.) levels of strategic listening. 
Witt's synthesis covers the role of the speaker, the role of the listener and the strategy for the listener to meet the purpose of the interaction. He touches upon basic interpersonal communication, and upon interactional, transactional and affective purposes. Brown and Yule (1993) have studied the pragmatic aspects that deal with what to say to who, with what purpose in a context and in a communicative situation.

\section{A structure for the development of listening}

The following section provides an overview of listening as a guide for practitioners, wishing to integrate the ideas presented to a program. The overlap with other skills represents the difficulty to parse language acquisition.

\section{A structure for the development of listening comprehension}

The description of the various strategies and behaviors included in Table No. 4 below, attempts to provide a complete detailed framework of the five types of knowledge listening calls for and the strategies associated with them.

1. Knowledge of the content and experience calls for strategies for generating ideas; 2. Procedural knowledge to organize the content calls for strategies for organizing ideas; 3. Knowledge of conventions of spoken discourse calls for strategies for editing ideas; 4. Procedural knowledge required to apply the other types of knowledge in comparing a spoken discourse calls for strategies for recognizing relevance; and 5. Procedural knowledge required to evaluate a spoken discourse calls for strategies for questioning textual information (taking a critical stand). Table 4 further illustrates the strategic knowledge related to listening. 


\begin{tabular}{|c|c|}
\hline $\begin{array}{l}\text { TYPES OF } \\
\text { KNOWLEDGE }\end{array}$ & STRATEGIES \\
\hline $\begin{array}{l}\text { 1. Know- } \\
\text { ledge of the } \\
\text { content and } \\
\text { experience } \\
\text { (images and } \\
\text { concepts) }\end{array}$ & $\begin{array}{l}\text { Strategies for recognizing ideas (identification of macroframe) } \\
\text { Identifying the goal. Decide why you are listening to the text and what } \\
\text { you are looking for in it. } \\
\text { Monitor your listening according to this goal. } \\
\text { Increase your exposure to the language. } \\
\text { Constructing mental images. Visualize and create images using the differ- } \\
\text { ent senses to better understand what you listen to. } \\
\text { Imagine the events and characters in goal-defined context based on the } \\
\text { prior knowledge and illustration included in the text. } \\
\text { Making predictions based on prior knowledge. Make judgments and } \\
\text { predictions based on prior knowledge of the topic or of the situation of } \\
\text { communication. } \\
\text { Do not listen from beginning to end if you can-look for specific informa- } \\
\text { tion, especially new and unfamiliar. } \\
\text { Study tables and pictures. } \\
\text { Activate vocabulary known. } \\
\text { Infer word meaning from the linguistic context in which it is embedded. } \\
\text { Be alert to phonological modifications in informal speech like contractions } \\
\text { or expressions like «gonna», "wanna». } \\
\text { Be alert to the use of expressions used to make a statement negative. } \\
\text { Chunking a stream of sound in order to decode it into a string of words } \\
\text { carrying propositional meaning. }\end{array}$ \\
\hline $\begin{array}{l}\text { 2. Procedural } \\
\text { knowledge to } \\
\text { organize the } \\
\text { content }\end{array}$ & $\begin{array}{l}\text { Strategies for organizing ideas (identification of schema) } \\
\text { Self-Questioning. Ask yourself questions before, during and after listening, } \\
\text { and look for the answers in the text if there is one. } \\
\text { Make sure what a main clause and a dependent clause state. } \\
\text { Clarify when confused (meta-cognitive skill). } \\
\text { Listen again (when possible); Skip for now; Look for the answers as you } \\
\text { listen. } \\
\text { Make guesses. Try to figure it out on your own, without asking someone } \\
\text { else. }\end{array}$ \\
\hline
\end{tabular}




\begin{tabular}{|c|c|}
\hline $\begin{array}{l}\text { 3. Know- } \\
\text { ledge of } \\
\text { conventions } \\
\text { of spoken } \\
\text { discourse }\end{array}$ & $\begin{array}{l}\text { Strategies for editing ideas (control and verification) } \\
\text { Summarizing. Hold the key ideas in your head as you read (make notes). } \\
\text { Distinguish important from less important ideas in text. } \\
\text { Look for a big idea in the text. } \\
\text { Integrate parts into the whole in order for it to make sense. } \\
\text { Become adept at synthesizing information within and across texts and } \\
\text { reading experiences. } \\
\text { Connect the text to prior knowledge based on your goal. } \\
\text { Identifying discourse features } \\
\text { Double check what /who the referential expressions (such as pronouns) } \\
\text { refer to. } \\
\text { Take advantage of redundant information that may appear in the listening } \\
\text { passage. E.g., repeated nouns. } \\
\text { Try to retain in memory the earlier as well as the later clause provided } \\
\text { about a piece of information. }\end{array}$ \\
\hline $\begin{array}{l}\text { 4. Procedural } \\
\text { knowledge } \\
\text { required to } \\
\text { apply the } \\
\text { other types } \\
\text { of knowledge } \\
\text { in compar- } \\
\text { ing a spoken } \\
\text { discourse }\end{array}$ & $\begin{array}{l}\text { Strategies for recognizing relevance of ideas (clarification and simplifica- } \\
\text { tion) } \\
\text { Cognitive and affective interpreting. } \\
\text { Monitor the adequacy of your understanding. } \\
\text { Repair faulty comprehension. } \\
\text { Choose the interpretation that fits in your existing world knowledge. } \\
\text { Reflect on what is heard in oral or written form. } \\
\text { Decide on the personal value the text has for you. }\end{array}$ \\
\hline $\begin{array}{l}\text { 5. Procedural } \\
\text { knowledge } \\
\text { required to } \\
\text { evaluate a } \\
\text { spoken dis- } \\
\text { course }\end{array}$ & $\begin{array}{l}\text { Strategies for questioning textual information (taking a critical stand) } \\
\text { Analyzing and critiquing issues of power and perspective that weave their } \\
\text { way through any text and any response. } \\
\text { Recognizing the speaker's purpose involves inferring a basis for choices of } \\
\text { content and language. } \\
\text { Recognizing tone and persuasive elements involves classifying the nature } \\
\text { of language choices. } \\
\text { Recognizing bias involves classifying the nature of patterns of choice of } \\
\text { content and language. }\end{array}$ \\
\hline
\end{tabular}

Table 4. Types of knowledge listening calls for and the strategies that go with them Castillo (2013). Adapted from several sources: O'Malley and Valdez (1996); Michael Pressley, as cited by Collington (2007); Keen and Zimmerman (1997) and Pearson (1992, in Harvey \& Goudvis, 2000, pp. 6-7); McDonough (1995, p. 57, cited by Fernández, 2006), Kucer (2005), Guthrie and Wigfield (2000). 
1. Knowledge of the content and experience (images and concepts) calls for strategies for recognizing ideas (identification of macroframe). Listeners need to get used to manipulate the material, to take notes and to support understanding with visual stimuli. A macroframe, such as the genre to which you are dealing with, is identified to tackle the listening text or passage.

\subsection{Identifying the goal}

Decide why you are listening to the text and what you are looking for in it.

1.1.1 Monitor your listening according to this goal. Kenneth Beare (n.d.) provides this advice for L2. Once you have begun to listen on a regular basis, you might still be frustrated by limited understanding. What should you do?

- Accept the fact that you are not going to understand everything.

- Keep cool when you do not understand, even if you continue to not understand for a long time.

- Do not translate into your native language. The attempt to translate «is only natural as we want to understand everything that is said. However, when you translate into your native language, you are taking the focus of your attention away from the speaker and concentrating on the translation process taking place in your brain».

1.1.2 Increase your exposure to the language through use of electronic media and authentic experiences. The possibilities that the Internet offer are countless: radio on line, T.V. on line, videos on line, etc.

\subsection{Constructing mental images}

Visualize and create images using the different senses to better understand what you listen to. Imagine the events and characters in goal-defined context based on the information and illustrations included in the text. Teachers may encourage the use of images by actually integrating them in their teaching. Use graphic organizers to show relationships across and between concepts.

For example, I used a Venn diagram to have beginning learners of Spanish as a foreign language to follow my presentation on Birthday celebrations in two cultures and cities (Colombian and North American). Then, they read 
the lyrics and heard the birthday song "Las mañanitas». In the Venn diagram, the section belonging to the city of Denver had: surprise parties, sweet sixteen, party, decorations, cake, cards, presents and the Happy Birthday song. The section representing the city of Bogota had: piñata, clowns, mariachis, the song "Las mañanitas» and quinceañeras. In the Venn diagram, the intersection had the words in Spanish: party, decorations, cake, cards, presents and the Happy Birthday song. The graphic representation showed the many similarities and facilitated the understanding of the message heard.

\subsection{Making predictions based on prior knowledge}

Make judgments and predictions based on prior information of the topic or of the situation of communication.

1.3.1 Do not listen from beginning to end if you can. Look for specific information, especially new and unfamiliar. If you are listening to recorded material, play it back.

1.3.2 Study tables, pictures or any other images that may make useful information available. They will help activate background knowledge and it may be easier to link, remember, recall and retrieve information.

1.3.3 Activate known vocabulary. Try to anticipate which content and expressions may come up.

1.3.4 Infer word meaning from the linguistic or the situational context, in which it is embedded.

1.3.5 Be alert to phonological modifications in informal speech, like contractions or expressions like «gonna«, «wanna», «/hæstə/» «l'd».

1.3.6 Be alert to the use of expressions used to make a statement negative and modify your interpretation accordingly.

\subsection{Chunking a stream of sound in order to decode it into a string of words carrying propositional meaning (Council of Europe 2001, p. 57)}

Aided by linguistic context, background information and situational clues, the listener makes sense of the meanings and messages encountered. The exercise proposed in the chapter on reading applies for listening. For example to work with a conference which script is available on line (such 
as in Ted.com ${ }^{\mathrm{TM}}$ ) the listener can copy and paste in Wordle $\mathrm{T}^{\mathrm{TM}}$ the script to decode the by obtaining a visual image.

2. Procedural knowledge to organize the content calls for strategies for organizing ideas. The identification of schema places concepts relationally, sequentially or hierarchically.

\subsection{Self-Questioning}

Ask yourself questions before, during and after listening, and look for the answers in the text -if there is one-.

\subsection{Ask questions of yourself, the authors you encounter and the texts you heard.}

e.g., How can I compare the ideas presented and my suppositions. How well do authors support their arguments?

\subsection{Make sure what a main clause and a dependent clause state.}

There are two main types of subordinate clause: conditional clauses and relative clauses.

Conditional clause: a conditional clause is one that usually begins with if or unless and describes something that is possible or probable:
If it looks like rain
a simple shelter can be made out of a plastic sheet.
[conditional clause]
[main clause]
I'll be home tomorrow unless the plane's delayed for hours.

\section{[main clause]} [conditional clause]

On the other hand, a relative clause is one connected to a main clause by a word such as which, that, whom, whose, when, where, or who:

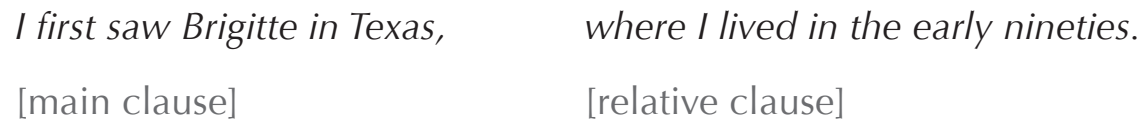


Lilly wants to be with Ricky, who is best suited to take care of her. [main clause] [relative clause]

\subsection{Seek for clarification when confused.}

Verify understanding of the facts, the meanings, the feelings and the intentions as the case may be.

Situation in which answers are provided, can be used as support to understanding.

2.5 Make guesses. Try to figure it out on your own, without asking a knowledgeable other.

3. Knowledge of conventions of spoken discourse calls for strategies for editing ideas (control and verification). Listeners try to exercise control over the information in an attempt to condense it and verify that the pieces of the puzzle fit.

\subsection{Summarizing}

3.1.2 Hold the key ideas in your head as you read (make mental notes).

3.1.3 Distinguish important facts from less important ideas in text.

3.1.4 Look for a big idea in the text. Do not give attention to detail until you have understood the main ideas.

3.1.5 Integrate parts into the whole in order for it to make sense.

3.1.6 Become adept at synthesizing information within and across texts and reading experiences.

3.1.7 Connect the text to prior information based on your goal.

\subsection{Identifying discourse features}

3.2.1 Double check what/who the referential expressions (such as pronouns) refer to. 
3.2.2 Take advantage of redundant information that may appear in the listening passage. E.g., repeated nouns.

3.2.3 Try to retain in memory the earlier as well as the later clause provided about a piece of information.

\section{Procedural knowledge required to apply the other types of knowl- edge in comparing a spoken discourse}

Strategies for recognizing relevance of ideas (clarification and simplification). The user needs to determine at which level the speakers are communicating at any given time, which include: a) facts; b) meaning; c) feelings, and $d$ ) intention. The ephemeral nature of listening requires the learner to confirm with different sources the hypothesis made. Visual sources, reading, knowledge about the topic or about the people involved may be some of the sources to solve the problems of understanding. The use of subtitles as you watch and listen to a program in a foreign language either on $T V$, in a podcast or on-line illustrate the above.

\subsection{Cognitive and affective interpreting}

\subsubsection{Monitor the adequacy of your understanding}

In addition to comprehension checks, the listener needs self-encouragement and reduce anxiety abut listening tasks.

\subsubsection{Repair faulty comprehension}

The listener needs to interpret at which level the speakers are communicating at any given time: 1 . Facts; 2 . Meaning; 3. Feelings; and 4. Intention.

4.1.4 Choose the interpretation that fits in your existing world knowledge. Discard hypothesis that are not plausible.

4.1.5 Reflect, in oral or in written form, on what is heard. Compare your notes with the others'.

4.1.6 Decide on the personal value the text or task has for you.

Goh and Taib (2006) reported a small scale study of metacognitive instruction for young L2 learners and claim that they reported a deeper un- 
derstanding of the nature and demands of listening and better strategies for coping with difficulties in comprehension.

\section{Procedural knowledge required to evaluate a spoken discourse calls for strategies for questioning textual information (taking a critical stand).}

These were discussed for reading, but since they apply to listening as well, they are enunciated here.

\subsection{Analyzing and critiquing issues of power and perspective}

Power and perspective weave their way through any text and any response. (c.f., Kucer 2001, p. 170).

5.1.1 Recognizing the speaker's purpose involves inferring a basis for choices of content and language.

5.1.2 Recognizing tone and persuasive elements involves classifying the nature of language choices.

5.1.3 Recognizing bias involves classifying the nature of patterns of choice of content and language.

\section{Discussion}

This chapter discussed the nature of listening, the levels of listening and the factors involved in strategic listening. The resources available from information technologies have not only expanded the possibilities of learning, but also have given birth to multi-literacies. We need to understand the worlds of contemporary learners who have access to aural and visual stimuli and who can look up large amounts of information in a couple of clicks. Therefore the teacher, as a guide on the side, can explore with the learner its potential for L1 and L2 acquisition.

As a summary, I cite Nunan (1999), who argues that listening can be classified:

according to a number of variables, including listening purpose, the role of the listener, and the type of text being listened to. These variables can be mixed and matched to give many different configurations, 
each of which will require a particular strategy on the part of the listener» (p. 204).

As stated previously, equipping learners with means that are related not only to their learning styles, but to their strategies to approach tasks, contributes to motivate them to learn independently (c.f., Castillo et al, 2007). The following chapter expands on that notion while concentrating on speaking. 


\section{Chapter IV \\ Strategic learning and speaking competence}

"There are three things to aim at in public speaking:

First to get into your subject, then to get your subject into yourself, and lastly, to get your subject into your hearers».

Gregg

Sociocultural factors such as the language of the wider society and the prestige associated to the L2 being acquired and used in the community play an important role in the decision to use the spoken language. In school settings the topics, the tasks proposed the supportive feedback and the promotion of communication strategies account for the development of speaking. This chapter concentrates on the latter.

Communication strategies refer the means the speaker exploits to activate and balance its resources, to set in motion skills and procedures, in order to fulfill the need of communication most proficiently. According to Scarcella and Oxford (1992, p. 154), proficient learners may use conversation management strategies (like turn-taking) or small talk to open a conversation and initiate and respond to talk on a broad range of topics, in spite of not having mastered the grammar fully. For instance, speakers need to quickly learn to identify the purpose of communication, which enables them to use appropriate and adequate language, constituted by, among other aspects, the setting, the intention, the speech act and the interlocutors. Then, decisions about register and style -formal, informal, neutral-can be made. In the classroom those decisions derive from the topic, from the source of the input -a reading passage, a recording or a video clip, for example. In a language program, a strategic component attempts to help learners become aware of strategy use and thus gain fluency. See Cohen, A. D.; Weaver, S. J. \& Li, Tao-Yuan (1996, p. 24) on enhancing strategy awareness.

On the other hand, languages differ on a number of dimensions, and the differences between one's L1 and the L2 can pose problems for the users who have difficulties in L1. For example, in the linguistic dimension appears 
the regularity of sound-letter correspondences. In the Spanish language, a single sound is usually represented by a single letter while in English one letter can represent several sounds; and a sound can be represented by several different letters. Then when someone tries to speak based on a text that is read, the difficulties appear. It is important that learners grasp the similarities and the differences of approaching L1 and L2 study. They need to acknowledge that the study of an L2 takes extra effort on their part, but that it is manageable and intellectually stimulating. The following section suggests a framework for the development of speaking.

\section{A structure for promoting L2 speaking}

A scaffold for strategic knowledge in speaking is expected to guide practitioners in their attempts to help learners become more independent. It is necessary to remember that speaking poses greater challenges to the learners' socio-affective factors; for example, self-image counts. Speakers need to accept their limited expression and consider it as part of their L1 or L2 development. Their commitment should not be affected; they need to be reassured that their strengths in listening, reading and writing shall work in favor of their oral proficiency. Lessons should stimulate what learners know for one or more aspects of speaking, such as confidence on what they already know or on their metacognitive skills. The grading and combination of texts and tasks -simple and complex- support scaffolding.

The structure has four types of knowledge for speaking and the strategies that are associated with them. The strategies for each type may overlap and are necessarily connected to the other three skills. Cultural aspects of speaking, such as norms of respect, and interrupting should be considered as well.

\section{Knowledge of the content and experience (images and concepts) calls for strategies for recognizing ideas (identification of macroframe)}

\section{1. Retrieval strategies}

Such as building previous information; e.g., using formulaic speech to feel on sure ground. Conversation openers such as «well», «I'd like to say 
that...», «In my opinion», "let me think" can be used automatically to progress to fluency.

\subsection{Rehearsing strategies}

Learners anticipate the interlocutor's response and the effect his/her words may have, such as calculating the effect of discourse structures. For example: in an oral presentation, the participant elaborates on some of the potential questions from the audience.

\subsection{Locating resources}

Looking things up in reference books or electronic devices, build confidence, as it is the case of oral presentations, inquiry at an information office or any other situation in which preparation is possible and desirable. Along those lines, looking for opportunities to use speech may prove to be effective for speaking development.

\subsection{Adjusting tasks}

Speaker may opt for a more modest version of the task or if confidence is built or resources are set in motion and the speaker may scale up the task (Council of Europe 2001, p. 63). Gaining awareness that not only the language may be adjusted, but the task should be useful for learners to better cope with it.

\subsection{Adjusting messages}

Linguistic or content support probably available later in the interaction may enable speaker to be more ambitious in forming or expressing thoughts (Council of Europe 2001, p. 63). Awareness of scalating his/her lexical accuracy, richness, variation, economy, metaphoricity, and phrasal complexity should be the concern of the speaker.

\subsection{Paraphrasing}

Speaker refers to a similar situation or may approximate words, or use non-verbal communication to solve a communication problem. Lanzetti (2013) presents a typology of paraphrasing across languages. 


\subsection{Paying attention to interlocutor reaction}

The speaker takes into account the feedback to fine-tune its speech. Notice if the other agreed, disagreed, followed up or ignored a comment.

\subsection{Taking risks}

Speakers try out some expressions as they talk. Trial and error would provide useful feedback. In lesson planning, teachers propose fluency tasks in which the language of instruction is used so that it can be easily acquired. Participants are attentive to use the language that the topic and the tasks demand.

\section{Procedural knowledge to organize the content calls for strategies for organizing ideas (identification of schema)}

\subsection{Stating goals}

(Why intervene) such as: making a plan or outline for creating an organized structure:

Is the speech well-organized?

How do I, as a speaker, use transition devices?

\subsection{Monitoring success}

Gauging feedback in terms of facial expressions, gestures and subsequent moves in the conversation, offer the speaker the opportunity to monitor the success of communication (Council of Europe, 2001, p. 63). 
Table No. 5. Types of knowledge speaking calls for and the strategies that go with them

\begin{tabular}{|c|c|}
\hline Types of knowledge & Strategies \\
\hline $\begin{array}{l}\text { 1. Knowledge of the } \\
\text { content and expe- } \\
\text { rience (images and } \\
\text { concepts) }\end{array}$ & $\begin{array}{l}\text { Strategies for recognizing ideas (identification of macroframe). } \\
\text { Retrieval strategies such as building previous knowledge. } \\
\text { Rehearsing strategies such as: } \\
\text { Calculating the effect of discourse structures; } \\
\text { Locating resources, looking things up to build confidence; } \\
\text { Task adjustment; } \\
\text { Message adjustment; } \\
\text { Paraphrasing; } \\
\text { Paying attention to interlocutor reaction; } \\
\text { Taking risks. }\end{array}$ \\
\hline $\begin{array}{l}\text { 2. Procedural knowl- } \\
\text { edge to organize the } \\
\text { content }\end{array}$ & $\begin{array}{l}\text { Strategies for organizing ideas (identification of schema). } \\
\text { Stating goals (why intervene) such as: making a plan or outline for } \\
\text { creating an organized structure: } \\
\text { Monitoring success; } \\
\text { Mediating. }\end{array}$ \\
\hline $\begin{array}{l}\text { 3. Knowledge of con- } \\
\text { ventions of speaking }\end{array}$ & $\begin{array}{l}\text { Strategies for editing ideas (control and verification). } \\
\text { Asking for clarification; } \\
\text { Taking the floor; } \\
\text { Co-operating; } \\
\text { Asking for clarification; } \\
\text { Structured reviewing; } \\
\text { Self-correction. }\end{array}$ \\
\hline $\begin{array}{l}\text { 4. Procedural } \\
\text { knowledge required } \\
\text { to apply the other } \\
\text { types of knowledge in } \\
\text { comparing a spoken } \\
\text { discourse }\end{array}$ & $\begin{array}{l}\text { Strategies for recognizing relevance of ideas (clarification and } \\
\text { simplification). } \\
\text { Revising cohesion or sequence; } \\
\text { Exposition of ideas and sentence variety; } \\
\text { Checking for style, purpose, clarity and register; } \\
\text { Taking questions; } \\
\text { Reflecting on your speaking process; } \\
\text { Repair faulty communication. }\end{array}$ \\
\hline
\end{tabular}

Castillo (2008). Adapted from several sources: O'Malley and Valdez (1996); M. Pressley, as cited by Collings (2007); Keen and Zimmerman (1997) and Pearson, 1992 (in Harvey \& Goudvis, 2000, pp. 6-7); Kucer (2005), McDonough (1995, p. 57, citedby Fernández, 2006), Guthrie and Wigfield (2000). 


\subsection{Mediating}

The speaker is not concerned to express his/her own meaning, but to mediate with others, when the language of the original text is not understandable to one of the interlocutors.

\section{Knowledge of conventions of speaking calls for strategies for editing ideas (control and verification)}

\subsection{Asking for clarification}

The learner asks follow up questions to check understanding, or appropriately ask for repetition about what was not understood.

\subsection{Taking the floor}

Speaker can initiate, maintain and end discourse appropriately with effective turn taking.

\subsection{Cooperating}

Speaker can relate own contribution skillfully to those of other speakers (Council of Europe, 2001, p. 86). There is a fine-tuning with the interlocutors.

\subsection{Structured reviewing}

Speaker can summarize the point reached in a discussion and so help focus the task (Council of Europe, 2001, p. 86).

\subsection{Self-correcting}

The speaker can identify and monitor errors in delivery or pronunciation vary the speaking speed or correct them errors. Tex-to speech tools available in the Internet allow the participant to enter a written text and hear it spoken at regular or modified rate. The pronunciation can be corrected following the recording. oral presentations can be edited in this manner. 


\section{Procedural knowledge required to apply the other types of knowledge in comparing a spoken discourse calls for strategies for recognizing relevance of ideas and coherence:}

\subsection{Revising cohesion or sequence}

Speaker monitors the thread of ideas striving for a logical flow of arguments. In rehearsed speech cue cards prove useful.

\subsection{Exposition of ideas and sentence variety}

Speaker works on openings, transitions and closings. Speaker is concerned with the logical structure of the speech and with engaging the audience using varied syntax.

\subsection{Checking for style, purpose, clarity and register}

Speaker is concerned with the flow of speech. Speaker can adjust utterances depending on the genre: storytelling, anecdote, dialogue, answering a question, public presentation, audience and situational context etc.

\subsection{Taking questions}

Speaker takes questions appropriately and answers adequately. For example, answer as such a yes/no question an either, or question or an information question. Of course, speaker must make sure the question was understood. If in doubt, ask for clarification.

\subsection{Reflecting on the speaking process and relating it to the product} quality. Self-evaluate the quality of delivery and the content of the intervention

\subsection{Repairing faulty communication}

Speaker can backtrack, and by using appropriate expressions, reiterate the message intended. The foci on strategic knowledge to promote speaking proficiency should a basis to enable learners to reduce anxiety in performance. Case in point, careful planning of spoken interaction in formal settings, add to fluency. 
Integrating strategies to a syllabus and including a phase of identification of the learner's level of strategy use and of development of awareness is highly recommended. What Chou (2004) affirms about socio-affective strategies is valid in general: "applying language learning strategies in the language classrooms should be treated as a long-term instruction» (p. 3). There is no positive variation between learners' speaking competence and the use of (socio-affective) strategies in a short period of the treatment. The successful acquisition of the speaking competence can be achieved only on condition that language teachers give the strategy use instruction patiently, and learners employ (socio-affective) strategies continuously.

In my experience, cognitive strategies, which act on the new information, are the first to be presented and discussed. These seem to be straight forward for they deal with how to approach the content of learning and contributes to grasp concepts more effectively and efficiently. Cognitive strategies pave the way to socio-affective and metacognitive strategies. 


\section{Chapter V Strategic learning and writing competence}

"The greatest part of a writers time is spent in reading, in order to write; a man will turn over half a library to make one book» Samuel Johnson

This chapter brings first a discussion on the perspective of writing as recursive, as opposed to a linear process. Second, approaches to ethnography of writing, primarily for the context offered to the student. Third, the conclusions of a research study on the connections between strategic behavior, knowledge and motivation, by Harris, Graham and Mason (2006), are offered. Finally, a structure to guide classroom-writing practices is put forward. A good deal of examples and illustrations, especially of visual organizers, are included with the intention of encouraging teachers to try them and to assess its effects.

\section{A theory of writing as a recursive process}

Writing refers to the act of producing or composing an original piece of discourse; it does not refer to using pen and paper to display understanding of a piece of grammar, or to respond to comprehension questions about a text. Gascoigne (2003) cites research in first language by Flower and Hayes (1981), involving think-aloud protocols, claiming that these studies provided a critical impetus for a shift from a linear to a recursive theoretical vision of the composing act. By observing writers in action, as opposed to analyzing the static final product, it can be concluded that there was a need for:

1. A greater focus on the strategies involved in "real-time» writing;

A consideration of the mental processes involved in composing; and

A vision of writing as complex and recursive (p. 1). 
Along these lines, writing is considered recursive, not linear; in other words, the writer has control over the output he/she has to revise and review continuously. Therefore, different types of knowledge are applied reiteratively. Writing also employs mental processes, procedures and strategies, which serve the phases of prewriting, writing and rewriting. Likewise, the types of knowledge and the strategies are not sequential.

Composing demands continuous decisions and choices that depend both on the function or purpose of writing and the audience. A writer makes different syntactic choices, for instance to persuade, comment, suggest or request which depend on the relation to the audience. When planning, executing and revising, writers (going back and forth) adjust the syntax, lexicon, pragmatic aspects and other features of language.

Therefore, educators insist that a good deal of time needs to be devoted to a planning stage in which the writer takes into account the language factors connected to audiences. Harris, Graham and Mason (2006) argue that:

Writing development involves changes that occur in children's strategic behavior, knowledge and motivation. The authors examined the effectiveness of self-regulated strategy development (SRSD), a strategy instructional model designed to promote development in each of these areas. Instruction focused on planning and writing stories and persuasive essays. The addition of a peer support component to SRSD instruction, aimed at facilitating maintenance and generalization effects, was also examined. SRSD had a positive impact on the writing performance and knowledge of struggling second-grade writers, attending urban schools serving a high percentage of low-income families (p. 295).

The above authors used planning as a key element to promote writing development. Strategic behavior was connected to the functions that story telling or essay writing demand. The more knowledgeable learners become about planning and the more aware they become about the particularities of a genre, the better the drafting and revising processes (for a discussion on genre pedagogy in L2 writing, refer to Hyland, 2007). The procedures described above, seeks to promote awareness of the steps and stages involved in writing. In Appendix 2 the recursive nature is illustrated both in the rubrics and in the product of a class assignment. 
The literature on academic writing, on the other hand, considers writing as the most conventionalized form of discourse; therefore, it is necessary to reflect on how language is used for different purposes in different contexts and on how writers perform their tasks. Grabe and Kaplan (in K. Bardovi-Harlig \& B. Hatford, 1997, p. 178) propose exploring ethnography of writing -primarily for the student context- arguing that a theory of social factors needs to include at least the situation in which the writing is done, the performance outcomes that represent the emergent features of the social context that invariably influence the ongoing writing process; and the cultural variation such as learner's expectations about teacher's behavior and instructional practices. In the ethnography of writing courses assign importance to local cultural orientations, to the rhetoric of writing genres and to shed light on part-whole relationships. In other words, writing practices attempt to be situated, to be appropriate and to promote coherence.

Writers need to gain awareness to adjust his expression of ideas and organize them on a number of levels. First are situation, settings and texts. For example, I asked an L2 class for college students of engineering to apply for a grant to attend a conference of their field. They were guided in the websites to become familiar with the genre, grant application. They introduced themselves, presented their university and their majors. They drafted a persuasive essay to explain why they should be chosen. Once they drafted the application, five other college students edited it on the screen. These juniors evaluated the task positively.

\section{A structure for strategic learning and writing}

Since this publication attempts to serve as a resource and as a reference for specialists as well as for language learners, this chapter, as the previous ones, brings a discussion on knowledge and strategies in which the reader will find some overlap. The examples provided, however concern writing.

Writing, as a complex process, needs to be viewed from its nature and from the steps that are necessary to succeed. In writing courses, teachers and learners must focus on the process, the product and the metacognitive aspects. This structure guides classroom practices for course designers and teachers, so that strategic knowledge allow learners to become more independent and efficient writers who rely on different types of knowledge and for one or more aspects of the act of writing (see O'Malley \& Valdez, 1996). 
Table 6. Types of knowledge writing calls for and the strategies that go with them

\begin{tabular}{|c|c|}
\hline TYPES OF KNOWLEDGE & STRATEGIES \\
\hline $\begin{array}{l}\text { 1. Knowledge of the content } \\
\text { and experience (images and } \\
\text { concepts) }\end{array}$ & $\begin{array}{l}\text { Strategies for generating ideas } \\
\text { Retrieval strategies such as: brainstorming, map- } \\
\text { ping, free write and group storytelling. } \\
\text { Search strategies such as: library and web search, } \\
\text { survey or interviews. }\end{array}$ \\
\hline $\begin{array}{l}\text { 2. Procedural knowledge to } \\
\text { organize the content }\end{array}$ & $\begin{array}{l}\text { Strategies for organizing ideas } \\
\text { Stating goals (why write?) such as: making a plan or } \\
\text { outline for creating an organized structure. } \\
\text { Using organizers such as: } \\
\text { T lists, family trees, fishbone, flow charts, timelines, } \\
\text { Venn Diagrams, problem-cause-effect organizers. } \\
\text { Checking layout and organization }\end{array}$ \\
\hline $\begin{array}{l}\text { 3. Knowledge of conventions of } \\
\text { writing }\end{array}$ & $\begin{array}{l}\text { Strategies for editing } \\
\text { Editing thoroughly. } \\
\text { Reviewing, reading backwards to catch typos, using } \\
\text { tools (dictionaries, thesaurus and grammar/spelling } \\
\text { check), following a model, peer editing, checking } \\
\text { notes, punctuation and connectors. }\end{array}$ \\
\hline $\begin{array}{l}\text { 4. Procedural knowledge requi- } \\
\text { red to apply to the other types } \\
\text { of knowledge in comparing a } \\
\text { written discourse }\end{array}$ & $\begin{array}{l}\text { Strategies for evaluating ideas } \\
\text { Strategies for recognizing relevance of ideas and } \\
\text { coherence: } \\
\text { Revising cohesion or sequence, transitions, elabora- } \\
\text { tion of ideas and sentence variety. } \\
\text { Checking for style, purpose, clarity and register. } \\
\text { Decide on relevance to the task. } \\
\text { Reflect on your writing process and relate it to the } \\
\text { product quality. }\end{array}$ \\
\hline
\end{tabular}

Castillo (2014). Adapted from several sources: O'Malley and Valdez (1996 ); M. Pressley, as cited by Collings (2007); Keen and Zimmerman (1997) and Pearson, 1992 (in Harvey \& Goudvis, 2000, pp. 6-7); Kucer (2005), McDonough (1995, p. 57, cited by Fernández (2006), Guthrie and Wigfield (2000). 


\section{Knowledge of the content}

The first type of knowledge that writing calls for is knowledge of the content. Learners need to draw on previous information and experience such as their images and concepts about the topic, or they consult literature that is relevant to the topic in order to gain knowledge about it (see Appendix 2). Learners need to make decisions on what to include, depending on the task. In compositions that include personal emotions or opinions, learners need to decide how much they want to reveal about themselves. Key strategies to stimulate knowledge of content and generate ideas are described below. Activities such as brainstorming, clustering, free-association and word-mapping are often included as part of the pre-writing or warm-up phase. Some examples are provided below.

\subsection{Brainstorming}

Cullen (1998) states that the purpose of brainstorming is to generate as many ideas as possible within a specified time-period. Each idea produced does not need to be usable; the ideas are not evaluated until later, when a wide range of ideas are often produced. Instead, initial ideas can be viewed as a starting point for more workable ideas. The principle of brainstorming is that you need lots of ideas to get good ideas. In the language classroom, brainstorming is often used in teaching writing. Cullen's study (1998) suggests that brainstorming had a strong positive effect on the atmosphere of the classroom and behavior of his students, which promoted immediate involvement.

For advance brainstorming techniques the reader may refer to: http://www. businessballs.com/kaleidoscopebrainstorming.htm

\subsection{Clustering}

Clustering also receives the name of semantic maps. Hess (2002, p. 102) proposes clustering for gathering ideas for writing fluency practice. The procedure proposed starts with the choice of a topic familiar to the learners. Then they write a topic in a circle (or on the top). Next, they draw branches, and finally, volunteers provide subtopics. Example: the word Travel is put at the center and others suggest words like Transport, Room and Board or Budget. Likewise, Figure No. 4 illustrates Cullen's (1998) example: «Write a word or phrase in the center of a page. All the other words or phrases should link off this in a logical manner». 
Figure No. 4

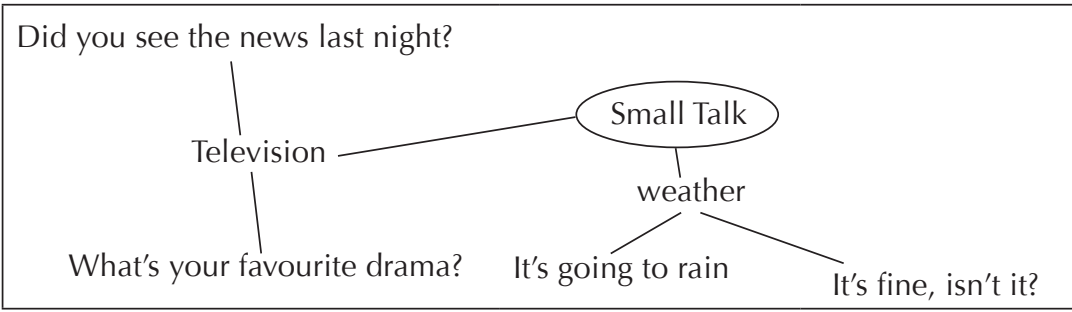

\subsection{Free write}

Writers can put on paper any ideas that come to mind to get started. Free writing may stimulate creativity (Castillo \& Hillman, 1995). In class, learners are allowed 3-5 minutes to jot down anything that comes to mind. The product of this writing does not necessarily have to become a topic nor has to be shared with the class. It is a catharsis, a venue for expressing ideas or from freeing yourself of the thoughts that inhibit or distract from getting started.

\subsection{Group storytelling}

Writing with others can stimulate idea generation. Cullen (1998) proposed using group storytelling in a classroom setting. Pupils work in groups and take turns adding to a story in which they are given the first line, either spoken or written.

\subsection{Search strategies}

Consulting various sources of information can also aid in the flow of ideas; it can help the writer activate prior information, make relationships, get inspiration and obtain new content.

\subsubsection{Library search}

Familiarization with library resources can help writers. Searching keyword, title, journal title, author and abstract, and other forms of consulting, contribute to activating ideas.

\subsubsection{Web search}

Learners benefit from becoming familiar with web search engines which query several research engines and compile and collate information. De- 
termining veracity of sources as well as determining reputable from less reputable sources is of utmost importance.

\subsection{Surveys}

Surveying classmates, friends, neighbors or parents may help writers to generate ideas. In the section further reading an example of a class survey, which get students to interact, is provided.

\subsection{Interviews}

Interviewing others about a certain topic, interviewing yourself or a hot seat interview can promote ideas for writing. They need to be transcribed and turned into a composition to serve as starters for writing.

\section{Procedural knowledge to organize the content}

For writing, procedural knowledge acts on the resources and it deals with the steps to carry out a task. For instance graphic organizers display the elements and the processes, and some are more suitable for certain types of writing. Graphs serve to summarize and charts to contrast.

2.1 State goals (why write) such as: making a plan or outline for creating an organized structure. Outlining is probably the most widely used of the pre-writing tools.

2.2 Check layout and organization. For stimulating the ordering of content and the display of information, the writer checks how it is presented.

2.3 Use organizers. Graphic organizers can be used across all subject areas, and have the potential to empower students to master subject matter faster and more effectively. See, for example, the website http://www. scoop.it/t/visual-literacy/p/356498888/2011/08/09/what-s-free-on-thissite-visual-literacy-k-8 and also Appendix 2.

2.3.1 $T$ lists. A " $\mathrm{T}$ " shaped list allows the writer to list; for example, on the left pros and on the right cons of a certain topic. Each entry can result in a paragraph.

2.3.2 Tree diagram. In a tree diagram, information is sorted into groups and subgroups. This helps us to see where details belong in a sequence 
of groups, where some groups fit inside others with practice, a writer can sketch the categories and subcategories to be covered adding fluency to the process of composing. For example, the group «poodles» would fit inside the group «dogs», which in turn would fit inside the group «animals».

Why use tree diagrams in the classroom?

- To understand visually the science concept of classification.

- To plan an informational report, this organizes information by looking at how it can be arranged in groups.

- To investigate social studies topics such as families and family trees.

Figure 5. A tree diagram.

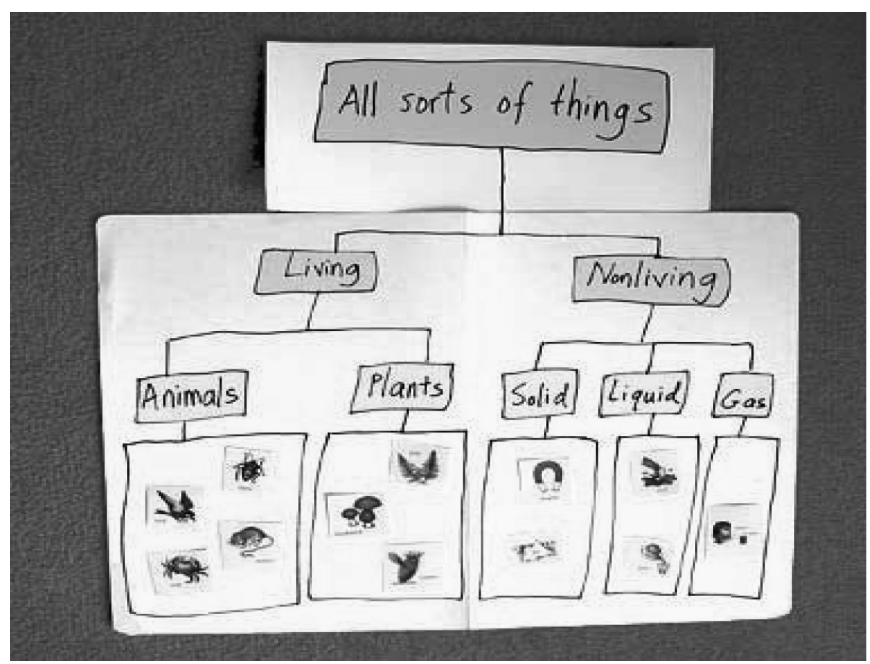

A tree diagram, like the one in figures, organizes items into groups. Its key features are:

- Main heading: names the whole group under which everything belongs.

- Group headings: name the groups that separate the items.

- Items: the things to be sorted into groups.

- Connecting lines: show how groups and items are related. Further discussion at: https://www.stenhouse.com/pdfs/0043guid.pdf

2.3.3 Fishbone \& Cause and effect diagrams. Dr. Kaoru Ishikawa, a Japanese quality control statistician, invented the fishbone diagram. It is an 
analysis tool that provides a systematic way of looking at effects and the causes that create or contribute to those effects. Its potential for writing es very high. The design of the diagram looks much like the skeleton of a fish. Therefore, it is often referred to as the fishbone diagram. The value of the fishbone diagram is to assist teams in categorizing the many potential causes of problems or issues in an orderly way and in identifying root causes. A fishbone diagram can be used when an individual or team:

- Needs to study a problem/issue to determine the root cause.

- Wants to study all the possible reasons why a process is beginning to have difficulties, problems, or breakdowns.

- Needs to identify areas for data collection.

- Wants to study why a process is not performing properly or producing the desired results.

Figure 6. Fishbone Diagram

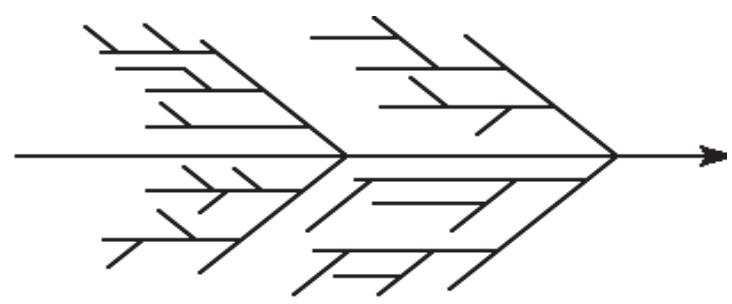

To successfully build a cause and effect diagram:

- Be sure everyone agrees on the effect or problem statement before beginning.

- Be succinct.

- For each node, think what could be its causes. Add them to the tree.

- Pursue each line of causality back to its root cause.

- Consider grafting/joining? Relatively empty branches onto others.

- Consider splitting up overcrowded branches.

- Consider which root causes are most likely to merit further investigation.

2.3.4 Flow charts. A flow chart is a visual text that shows a series of steps in a sequence. Key features: 
- Arrows show the order in which to read the text.

- Labels name things (the rain, the lake) or processes (rain falls, lake fills).

- Chains arrange items in a single line.

- Forks split one chain into two or more chains.

- Loops are used to repeat some or all of the steps.

Figure 7. Flowcharts

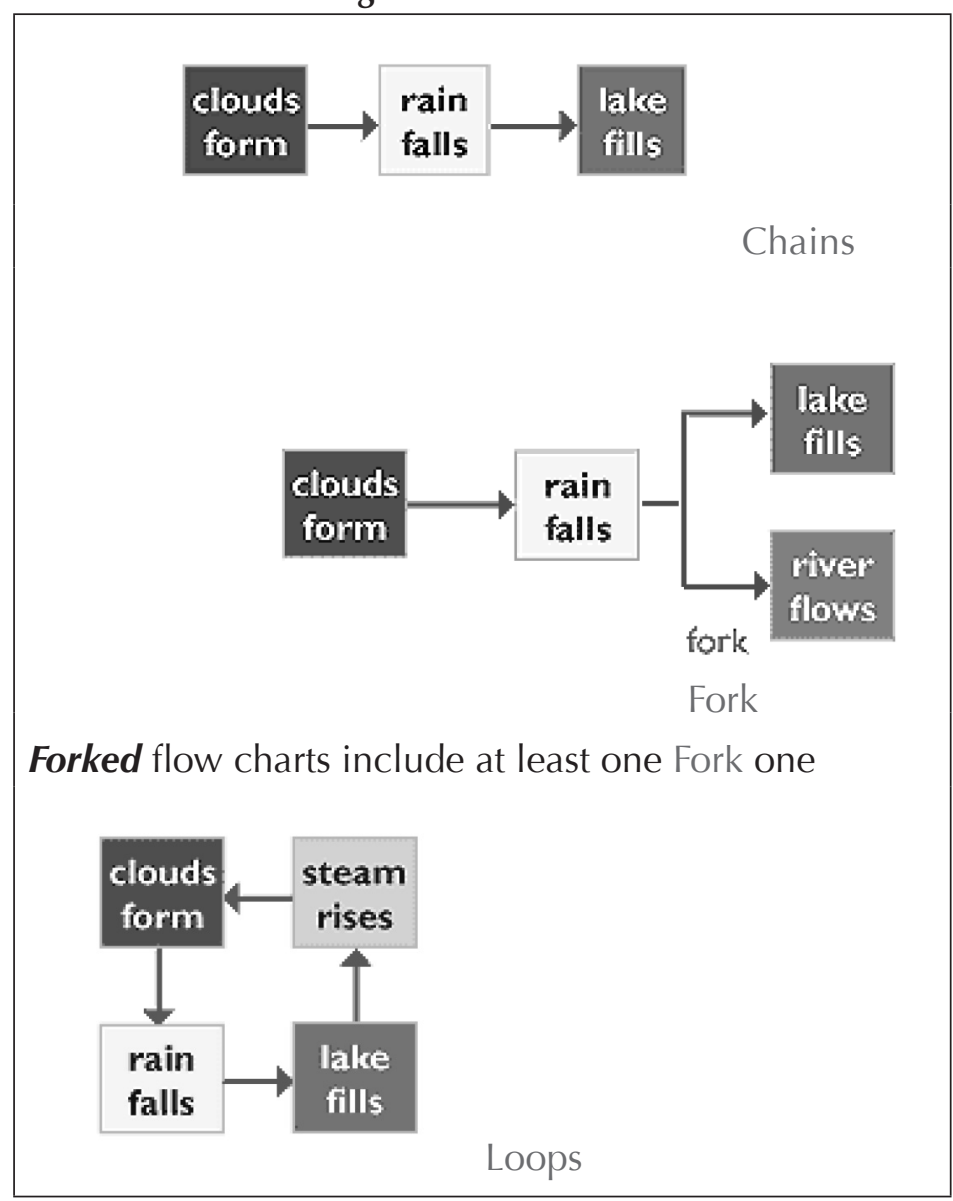

2.3.5. Timelines. Continuum or timeline diagrams are a type of graphic organizer used to represent a continuum of data that occur in chronological or sequential order. If the topic has a definite beginning and/or ending points, and the data points in between are not discrete, use a continuum/ timeline. For example, a continuum or timeline diagram can be used to display milestones in a person's life. In making a timeline, the student must 
first determine appropriate endpoints for the timeline and important points/ dates to label on the continuum.

Figure 8. Timelines

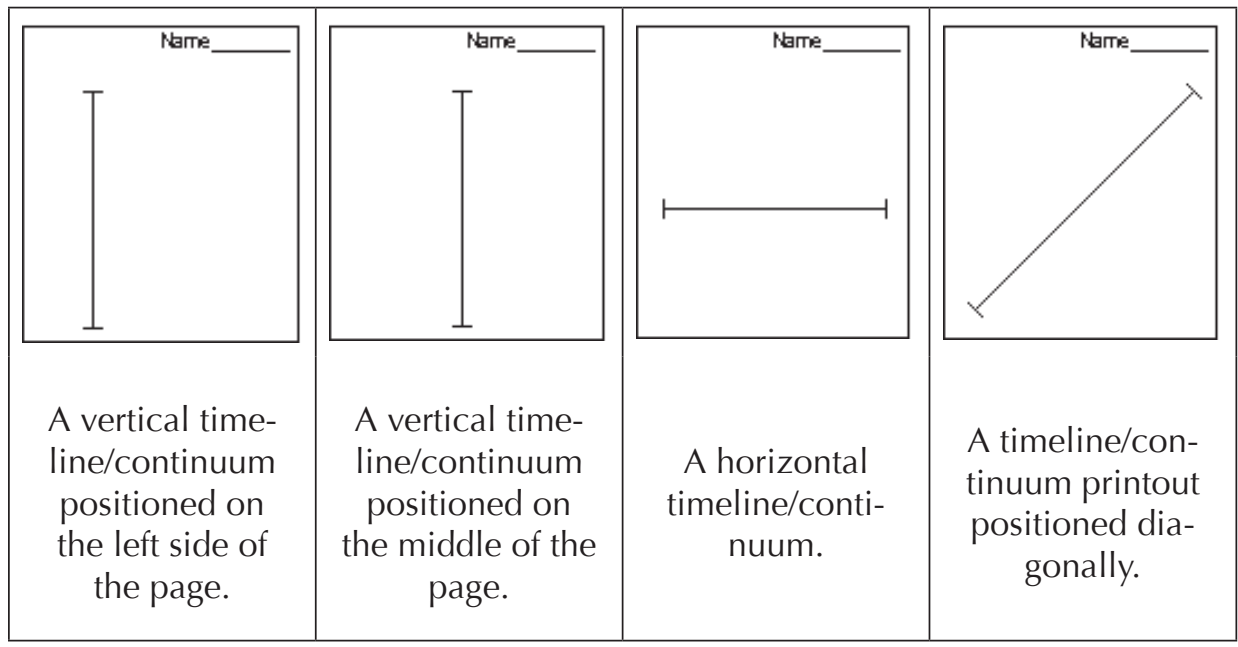

Source: http://www.enchantedlearning.com/graphicorganizers/timeline/

2.3.6 Venn Diagrams. A Venn diagram is a drawing, in which circular areas represent groups of items sharing common properties. The drawing consists of two or more circles, each representing a specific group. John Venn devised this process of visualizing logical relationships. When a writer manages to synthesize goal and purpose in a graphic organizer, like a Venn diagram, he/she is halfway to succesful composing.

Figure 8. Venn Diagrams
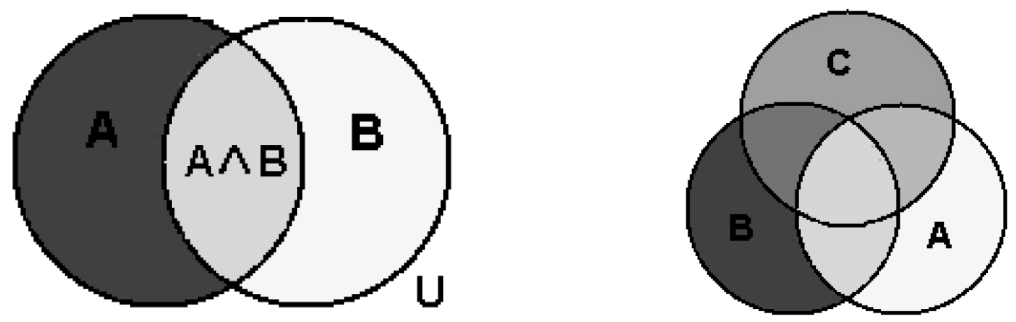

The Venn diagram on the left shows two sets $\mathbf{A}$ and $\mathbf{B}$. Values that belong to both set $\mathbf{A}$ and set $\mathbf{B}$ are located in the center region labeled $\mathbf{A} \wedge \boldsymbol{B}$, where 
the circles overlap. The notation $\mathbf{A} \mathbf{v} \mathbf{B}$ represents the entire region covered by both sets, $\mathbf{A}$ and $\mathbf{B}$. If we cut out sets $\mathbf{A}$ and $\mathbf{B}$, the remaining region in $\mathbf{U}$ would be labeled $\sim(\mathbf{A} \mathbf{v} \mathbf{B})$.

The Venn diagram to the right shows three sets, $\mathbf{A}, \mathbf{B}$ and $\mathbf{C}$. Values that belong to set $\mathbf{A}$, set $\mathbf{B}$ and set $\mathbf{C}$ are located in the center region labeled $\mathbf{A}$ ^ B ^ C C, where the circles overlap. This ability to represent a «sharing of conditions» makes Venn diagrams a tool for outlining an extended piece of writing. In the section further reading «e», Venn diagram for problem solving is illustrated.

\section{Knowledge of conventions of writing}

Writing calls for acquaintance of its conventions since its form greatly depends on the audience, the purpose and the genre. In order to write effectively, learners required familiarization of discourse structures, syntactic forms and conventions for each type of writing. E.g., there are protocols for writing academic papers (see Castillo, 2000) or for writing Emails.

3.1 Organizing writing according to type (or genre). Teachers must help students understand the characteristics of each genre to write accordingly, depending on the form, e.g., stories, compositions, reaction paper, lab reports or research reports. For example, a story requires a conflict, a resolution and a coda, while an anecdote creates a single, memorable picture of a situation in which you were involved, and that is relevant to the person you are talking to or to the subject of the conversation.

\subsection{Expressing meaning through syntactic constructions and writing con-} ventions. Writers should respect the conventions according to the situation, the status of readers or degree of formality.

3.3 Editing thoroughly. Review, using tools both in hard copy and electronic ones, such as dictionaries, word references and grammar/spelling check. Review the text produced carefully by looking up words in regular or specialized dictionaries or other reference tools. If using grammar and spell check on a computer; it is important to attend to the colored indicators (red and green) that appear to suggest fragment, punctuation, spelling errors, etc. The author uses Wordle $\mathrm{T}^{\mathrm{TM}}$ as an editor since words are displayed by frequency, and the writer can spot the relevance or the overuse of a word 
(see Appendix 2, Task 1). Once spotted the command 'find' in the word processor, it tells you how many times certain word is used. The writer can then opt for a synonym or a turn of phrase.

3.4 Following a model. Learners may build confidence by 'studying' the organization and the syntax of a given passage or text. In several genres like letters or résumés models are useful. In the Internet you can find templates and samples for diverse genres.

3.5 Peer editing. Working with others facilitates the writing process and promotes a collaborative atmosphere conducive to learning. Peer editing can be used at different stages: for content, for ideas or for grammar. Guilford (2001) conducted a study on teaching peer review to undergraduate students, concluding that it resulted in much higher quality in manuscripts, higher grades, greater objectivity in grading and improved understanding. Guilford warns that the guidelines for the review by peers must be very clear and must be enforced. It also must be modeled and practiced. It is also best employed for intermediate proficient writers. It can be modeled orally in a shared writing context for younger and less proficient writers.

3.6 Checking: notes, punctuation and connectors. Re-reading (silently or aloud) with the specific purpose of noticing one aspect such as inclusion of marginal notes, punctuation or use of connectors, can potentially increase the quality of a composition. On the other hand, reading backwards constitutes a straightforward method to catch typos, misspellings or other grammatical errors, because this type of revision concentrates on the form rather than on the content.

\section{Procedural knowledge required to apply the other types of knowledge in comparing a written product}

"The skill of writing is to create a context in which other people can think». Edwin Schlossberg

The fourth type of knowledge writing calls for is procedural knowledge. The act of writing as described before is recursive and complex, therefore, after ideas are generated, organized and edited, the writers need to go back 
to the text and turn their attention to coherence and cohesion by combining all types of knowledge.

4.1 Decide on relevance to the task. The writer studies the text and compares it with the purpose, the task or the rubrics.

4.2 Revising sequence, transitions, elaboration of ideas and sentence variety. At this stage, the writer revises cohesion, flow of ideas, transitions, as well as the syntactic variation in the sentences used (Peterson \& Hagen, 1999).

4.3 Checking for style, purpose, clarity and register. The writer revises the complete text according to the purpose and intention of communication, the audience, the genre (e.g., essays, journal entries, research reports, learning logs, or summaries) and the type of writing (expository, informative, expressive, narrative and persuasive).

4.4 Reflect on the writing process and relate it to the product quality. This metacognitive strategy involves monitoring one's production and evaluating learning after a writing task is completed. Teachers and learners exchange ideas on the aspects of the written process to concentrate on. It might be good to show drafts of the process and how the writing action improves the end product.

\section{Discussion}

Writing calls for content and experiential knowledge (images and concepts), for procedural knowledge to organize the content, for knowledge of writing conventions and for procedural knowledge required to apply the other types of knowledge to a written piece. These are associated with key aspects of writing (generating ideas, organizing ideas, editing and evaluating ideas) and with strategies. For each aspect of writing, there is a good repertoire of strategies that the writer can apply to make the tasks more manageable. The sources cited give an account of the implementation of strategies by innovative classroom teachers.

Writers and writing teachers benefit from understanding the complexity of writing. Teachers are encouraged to observe the processes and investigate how learners apply and perceive the integration of strategies. It is here claimed that the awareness of the communicative situation, of the perfor- 
mance outcomes and of the cultural/social variation involved in writing, requires the understanding of the strategy, and that the path to successful writing requires a higher order, thinking that can be mediated by strategies applied adequately.

It is also claimed that the activation of background (declarative) knowledge on the content, on the experiences about the content and about the experiences in writing, facilitate the completion of writing tasks. Yan (2010) presents a case in point. His study demonstrated that a good command of metacognitive knowledge can empower EFL learners in their English writing and cultivate their learning autonomy.

Editing and proofreading intensively allows writers to look at the text from other angles very much in the way in which an apprentice of painting trains by inverting the canvas (as in the picture on p. 18) to refine details.

In sum, the promotion of procedural knowledge for giving the text an organization and a structure can prove useful. The writer needs the acquaintance with the conventions of writing. The evaluation of ideas through the use of strategies help the writer to backtrack and look at the text in its integrity; and finally, a venue of research deals with exploring how a syllabus can be constructed and implemented. 


\section{Chapter VI \\ Implications of strategic learning for language education}

To excel means to reach beyond the best you have ever given because doing so matters to you personally, for its own sake. It means to run your own race -as an individual, team, or organization. To excel is to know your greatest strengths and passions, and to emphasize them while honestly admitting and managing your weaknesses.

Robert Cooper

This chapter will expand on the implications of implementing strategic learning in teaching. The main recommendation of this book is that schools integrate strategic knowledge to their language syllabi in order to help teachers and learners prioritize their capacities to better examine, understand and judge the world. Appendix 2 brings an assignment in which a graduate student follows the strategies implemented in an academic English course the author teaches. This illustrates a strategy-oriented approach to teaching and learning an L2. The high quality of the product is due to the graduate student understanding of the tasks and to the good use of strategies. The feedback provided for the abstract was included.

The integration of strategies to a program requires the inclusion of a strand of strategies following seven principles as claimed by Pressley (1992, in Collings, n.d., p. 6):

1. Such teaching is long-term.

2. Explanations and teacher modeling of one or more strategies occur in every class.

3. Teacher guidance is the most prominent mode of instruction.

4. Teachers discuss, endorse and model flexible strategy use.

Acquisition of repertoires of effective and complementary strategies is the ideal. 
6. Teachers consistently send the message that student thought processes are what count rather than getting a specific «correct» answer.

7. Strategies instruction is integrated with the content instruction.

The integration of strategic knowledge, familiarity of cognitive tasks and self-knowledge to a syllabus, may serve to promote autonomy. Learners benefit from understanding how to approach learning, how to best tackle a task, and how to understand the significance and value of reflection about learning. I am in accord with Skehan (1998), who advocates a process syllabus in which:

The learner is given power not only to interact but also to control the nature of the interactions which take place. The learner participates in the decision-making process and works with other learners and the teacher to decide what will be done in the language class and how it will be done. Learners need to know how to be effective learners since they are given considerable autonomy and power while teachers need to be able to accept a very different position with respect to their authority (p. 262).

Two studies are presented to illustrate the implications for teaching, learning and research. Nunan (1997) set out to:

investigate the effect of strategy training on student motivation, students' knowledge of strategies, the perceived utility of strategies, and their actual deployment of strategies. Results of the study indicated significant differences in three of the four areas investigated. The experimental groups significantly outperformed the control groups on motivation, knowledge, and perceived utility. There was no significant difference in the area of deployment. Analysis of results on individual strategies revealed that strategy training was neither uniform nor consistent across all strategies (p. 1).

Nunan advocates for the overt teaching of strategies even if some learners do not use some strategies, as was the case for the college participants he studied.

By the same token, Nyikos (2004, p. 45) contends that the use of strategies is interrelated to the importance of attention to the teacher, to the task and to the sociocultural influences. For example, Nyikos found that younger adolescents rely more heavily on socio-cognitive factors eschewing strictly cognitive approaches to language learning. Her study suggests that younger 
students appear to rely on social mediation more so than the older students. She argues for enhancing cognitive connections through tasks that create and use social interconnections. Then the inclusion of a strand of strategies must think about the age of the learners, their motivations and their learning preferences.

Castillo and Camelo (2013), in a study on how parents can support L2 acquisition, argue that training parents in strategic learning helps their children's school achievement. The kids can make sense of the game of learning when they and their parents expand their repertoire of learning strategies.

Following Trenado (2004), Oxford (1990:203), Oxford (2013), Ellis (1994, pp. 557-558) and O'Malley and Chamot (1990, pp. 157-160; 190-204), it is important to take into account the following aspects in order to implement a strategy-training program:

1. Have reliable data on the learners' current use of strategies.

2. Determine learner needs and time available. You should be able to answer these questions? Who are the learners? What do they do to learn? Which strategies do they want to learn first? etc.

3. Select strategies well keeping in mind the participants' background and culture.

4. Strategy training works best when integrated to the program goals, to the tasks and to the materials.

5. Consider motivational issues. How will motivation be built into the training program? How will progress in strategies be assessed? For instance, a percentage of the grade or partial credit is given for attaining new strategies.

6. Prepare materials and activities. You may want to prepare a handbook for learners to use in class and at home or learners may carry a strategy $\log$.

7. Conduct completely informed training. Learners must fully understand why strategies are important and how strategies can transfer to new situations.

8. Evaluate the strategy training by observing learners or by implementing self-evaluation of strategy use.

9. Revise the strategy training. Following the steps above, make adjustments in the program according to the information gathered and do the steps above mentioned, once again. 
On the other hand, integrating strategic knowledge to a curricula attempts to develop both, the language and the subject matter aspects. It deals with declarative knowledge, procedural knowledge, as well as with situational knowledge. Strategies are overtly taught and use of the strategies should be accompanied with raising awareness on their use. Strategic learning identifies phases of preparation, presentation, practice, evaluation and transfer of the strategies. It aims at promoting autonomous learning and assigns priority to the learner's participation. Genre theory (Hyland, 2007) has explored the connection between the types of texts, the audience, the purpose and the rhetorical organization as key elements for strategic writing.

Further research is needed to test the relationship between the types of knowledge presented in this proposal, as well as to the relationship, if any with age. Research is also needed in the areas of strategic knowledge for grammar and vocabulary learning, which literature is scarce.

In closing, the author would like to reiterate the thesis put forward in this publication. There needs to be a try-out and experimentation of instruction in strategic knowledge. It is necessary to find out and document the possible impact on achievement that can be attained by instruction rich in the components of strategic knowledge. It will be beneficial undoubtedly, but we need to learn how to do it harmonically within a curriculum. Reflective practice and research are needed to better understand the teaching and learning language strategically.

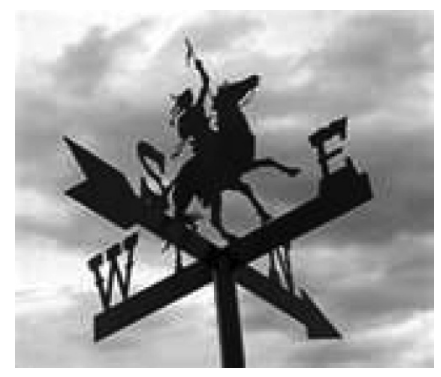

It's easy to act as if you are a weathervane, always changing your beliefs and words, trying to please everyone around you. But we were born to be lighthouses, not weathervanes. 


\section{References}

Bachman, L. (1990). Fundamental considerations in language testing. Oxford: Oxford University Press.

Bardovi-Harlig, K. \& Hartford, B. (Eds.) (1997). Beyond Methods: Components of L2 Teacher education. NY: McGraw-Hill.

Beare, K. (n.d.). Improving listening. Retrieved May 3, 2013. Available at: http://esl. about.com/od/englishlistening/a/listen_tips.htm.

British Council and BвC (n.d.). Teaching English. Retrieved December 1, 2010. Available at: http://www.teachingenglish.org.uk/

Bourke, J. M. (2008). A rough guide to Language Awareness. In: English Teaching Forum 46(1), pp. 12-21.

Bouvet, E. (2002). Reading in a foreign language: Strategic variation between readers of differing proficiency. Vol. 1(1), March. Available at: http://www.ehlt.flinders. edu.au/deptlang/fulgor/

Bradford, K. (n.d.). Deep and surface approaches to learning and the strategic approach to study in higher education; Based on Phenomenographic Research. Retrieved March 28, 2007. Available at: http://www.arasite.org/guestkb.htm

Brown, G. \& Yule, G. (1993). Análisis del discurso. Madrid: Visor Libros.

Canale, M. \& Swain, M. (1980). Theoretical bases of communicative approaches to second language teaching and testing. In: Applied Linguistics (1) pp. 1-47. Retrieved November 5, 2013. Available at: http://ibatefl.com/wp-content/ uploads/2012/08/CLT-Canale-Swain.pdf

Castillo, R. \& Camelo, L. (2013a). Assisting your Child's Learning in L2 is like Teaching them to Ride a Bike: A Study on Parental Involvement. In: Gist: Revista Colombiana De Educación Bilingüe/Colombian Journal Of Bilingua Education (1) 7, pp. 54-74.

Castillo, R. \& Vargas, J. C. (2013b). Situated learning for adults acquiring a second language. In: Latin American Journal of Content and Language Integrated Learning 6(1), pp. 20-36. Available at: doi:10.5294/laclil.2013.6.1.2 elSSN 23229721. 
Castillo, R. (2012a). Editorial introduction: A reflection on the role of foreign language learning in today's education. In: Latin American Journal of Content and Language Integrated Learning 5(2), pp. iv-vii. Available at: http://laclil.unisabana.edu.co/index.php/LACLIL/article/view/laclil.2012.5.2.11

Castillo, R. \& Díaz, N. R. (2012b). Supporting Student-Teacher-Researchers' Quest for Their Voice. In: How Journal 19, pp. 185-193. Bogotá, Colombia. December.

Castillo, R. \& Díaz, N. R. (2012c). Guiding Teacher-Researchers to Narrate their Stories: The Research Course. Proceedings of the ELT Symposium, pp. 1-6. Bogotá: Centro Colombo Americano. Available at: http://hasp.axesnet.com/contenido/documentos/ProcedingsSymposium.pdf

Castillo, R. (2011). Educational plays for learners of English. Proceedings from The Asian Conference on Language Learning. Osaka, Japan. Retrieved June 11, 2013. Available at: http://iafor.org/acll_split/ACLL2011_0029.pdf

Castillo, R. (2008). Issues Involved in Context, Comprehension and Content. In: Latin American Content and Language Integrated learning 1(1), pp. 15-25. Available at: http://laclil.unisabana.edu.co/index.php/LACLIL/article/view/laclil.2008.1.1.2

Castillo, R.; Zorro, I.; Benjumea, A. \& Baracaldo, D. (2007). Autonomía y aprendizaje de las lenguas extranjeras. Bogotá D. C.: Universidad Libre de Colombia.

Castillo, R. (2006). La formación de capital humano en lenguas extranjeras. En: Agenda Regional de competitividad para Cundinamarca y Bogotá, pp. 232254. Bogotá: Universidad Distrital, CARCE, COLCIENCIAS, SENA.

Castillo, R. (2006). Elementos de una propuesta para la enseñanza del inglés: Una mirada a seis contextos. En: Revista Científica(7), pp. 153-181. Bogotá: Universidad Distrital Francisco José de Caldas.

Castillo, R. (2004). Estrategias de aprendizaje: Lecciones de una clase de lengua extranjera. En: Cartilla Grancolombiana. Bogotá: Universidad La Gran Colombia.

Castillo, R. (2002). La nivelación como estrategia metodológica para el aprendizaje del inglés como lengua extranjera: un estudio de prácticas de manejo de grupos y de estudiantes. En: Revista Científica 4(1), pp.141-172. Bogotá: Universidad Distrital Francisco Jose de Caldas.

Castillo, R. (2000). Pitfalls in writing academic reports. In: How Journal. Colombia: Asocopi. 
Castillo, R. (1991). Teaching Learners to learn. In: English Teaching Forum (XXIX)3. Washington: USIA.

Castillo, R. \& Hillman, G. (1995). Ten ideas for creative writing. In: English Teaching Forum (33)4, pp. 301-31. Washington: USIA. Also available at: http:// exchanges.state.gov/forum/vols/vol33/no4/p30.htm

Chamot, A. U.; Barnhartdt, S.; Beard El-Dinary, P. \& Robbins, J. (1999). The learning strategies handbook. NY: Longman.

Chauhan, V. (2004). Drama techniques for teaching English. In: The Internet TESL Journal (X)10, October 2004. Retrieved Feb. 10, 2008. Available at: http://iteslj. org/

Chou, Y. L. (2004). Promoting learners' speaking ability by socio affective strategies. In: The Internet TESL Journal (X)9, September 2004. Retrieved Jan. 15, 2008. Available at: http://iteslj.org/Articles/Chou-Socioaffective.html.

Cohen, A. D.; Weaver, S. J. \& Li, Tao-Yuan (1996). The impact of strategies-based instruction on speaking a foreign language. In: Research Report, pp. 1-51. Retrieved May 6, 2013. Available at: http://www.carla.umn.edu/strategies/resources/SBlimpact.pdf.

Cohen, A. D. (1996). Second language learning and use strategies: clarifying the issues. Center for Advanced Research on Language Acquisition University of Minnesota, Minneapolis, pp. 1-26. Retrieved Sept. 7, 2012. Available at: http:// www.carla.umn.edu/strategies/resources/SBIclarify.pdf.

Collings, N. (n.d.). Psychology of literacy that teachers need to know. Retrieved Jan. 31, 2007. Available at: http://www.msu.edu/ ignatova/cep912.doc

Council of Europe (2001). Common European framework for Languages: Learning, teaching, assessment. Cambridge: Cambridge University Press.

Cullen, B. (1998). Brainstorming before speaking tasks. In: The Internet TESL JOurnal (IV) 7, July 1998. Retrieved Nov. 2, 2007. Available at: http://iteslj.org/.

Eagle Express (2012). Retrieved Feb. 27, 2012. Available at: http://coventrychristian.com/documents/2.27.12.pdf

Ellis, R. (1995). Noticing. Tesol Quarterly (29)1.

Fernández, P. (2006). Entrenamiento estratégico en la enseñanza de la comprensión lectora del inglés como lengua extranjera. En: PortaLinguarum, 6, pp. 7-22. 
Gascoigne, C. (2003). The role of the outline in L2 composition. Academic Exchange Quarterly 7(1).

Gagné, E. (1985). The cognitive psychology of school learning (1 ${ }^{\text {st }}$. ed.). Boston, U.S.A: Little Brown and Company.

Goh \& Taib (2006). Metacognitive instruction in listening for young learners.In: ELT Journal 60(3), pp. 222-232. London.

Guilford, W. (2001). Teaching peer review and the process of scientific writing. Retrieved Nov. 29, 2007. Available at: http://advan.physiology.org/cgi/reprint/25/3/167.

Harris, K. R; Graham, S. \& Mason, L. H. (2006). Improving the writing, knowledge and motivation of struggling young Writers: Effects of self-regulated strategy development with and without peer support. In: American Educational Research Journal (43)2, pp. 295-328. Washington. Available at: http://www.sagepub. com/donoghuestudy/articles/Harris\%20Graham\%20Mason.pdf

Harvey, S. \& Goudvis, A. (2000). Strategies that work: Teaching comprehension to enhance understanding. Portland: Stenhouse Publishers.

Hess, N. (2002). Teaching large multilevel classes. Oxford: Oxford University Press.

Hyland, K. (2007). Genre pedagogy: Language, literacy and L2 writing instruction. In: Journal of Second Language Writing 16, pp. 148-164. Retrieved May 2, 2012. Available at: http://www2.caes.hku.hk/kenhyland/files/2012/08/Genrepedagogy_language-literacy-and-L2-writing-instruction1.pdf

Iturain, M. M. (n.d.). Doing surveys. Retrieved Oct. 11, 2009. Available at: http:// www.teachingenglish.org.uk/search/apachesolr_search/surveys $\% 20$ use

Kamil, M. L.; Mosenthal, P. B.; Pearson, P. D. \& Barr, R. (Ed.) (2000). Handbook of Reading Research (Vol. III). Retrieved May 7, 2012. Available at: http://www2. caes.hku.hk/kenhyland/files/2012/08/Genre-pedagogy_language-literacyand-L2-writing-instruction1.pdf.

Kostin, I. (2004). Exploring item characteristics that are related to the difficulty of TOEFL dialogue items. In: ERIC, Research Reports. RR-79. RR-04-11 (Record Details 492925), pp. 1-69. Available at: http://www.eric.ed.gov/.

Kang, S. (2004). Using visual organizers to enhance EFL instruction. In: ELT Journal (58)1, pp. 58-67. 
Kucer, S. (2005). Dimensions of literacy: A conceptual base for teaching reading and writing. Mahwah, NJ: Lawrence Erlbaum Associates, Inc.

Lambton School District (2008). Lesson Ideas: Language Strategies Linked To The Grades 4-8 DRA Including "Think Literacy" Strategies. Retrieved Dec. 5, 2012. Available at: http://www.Ikdsb.net/program/elementary/intermediate/Intermediate\%20Lesson \%20Ideas\%20Strategies\%20Linked\%20To\%204\%20-\%20 8\%20DRA\%202007.pdf

Lanzetti, R. (2013). How to learn foreign languages - Paraphrasing. Available at: https://www.youtube.com/watch?v=_MjNSI5mWEQ

Lessard-Clouston, M. (1997) Language learning strategies: An overview for L2 Teachers. In: The Internet TESL Journal. Retrieved Dec. 1, 2012. Available at: http:// iteslj.org/Articles/Lessard-Clouston-Strategy.html

Livingston, J. (1999). Metacognition: An Overview. Retrieved May 2, 2013. Available at: http://gse.buffalo.edu/fas/shuell/cep564/metacog.htm

Lublin, J. (n.d.). Deep, surface and strategic approach to learning. Dublin: UCD, Centre for teaching and learning: good practices in teaching and learning. Retrieved Jan. 4, 2011. Available at:http://www.ucd.ie/teaching/printableDocs/ Good\%20Practices\%20in\%20T\&L/deep\%20surface\&stragtic\%20approa-

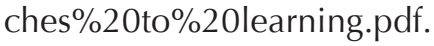

Merriam Webster Dictionary. Available at: http://merriam-webster.com/dictionary.

Ministerio de Educación Nacional, Colombia-MEN (2004). Estándares básicos de competencias del lenguaje. Retrieved Aug. 17, 2008. Available at: http://www. mineducacion.gov.co/1621/articles-116042_archivo_pdf1.pdf

Ministerio de Educación Nacional, Colombia-MEN (2006). Estándares básicos de competencias en lenguas extranjeras: Inglés. Retrieved Jun. 23, 2009. Available at: http://www.colombiaaprende.edu.co/html/mediateca/1607/articles-115375_archivo.pdf

Montgomery, B. M. \& Baxter, L. (2013). Dialectical approaches to studying personal relationships. Mahweh, N. J.: Erlbaum.

Nunan, D. (1999). Second language teaching and learning. Boston: Heinle \& Heinle. 
Nunan, D. (1997). Strategy training in the language classroom: an empirical investigation. In: RELC Journal, (28)2, pp. 56-81.

Nyikos, M. (2004). Retrieval Networks: tapping into the Interaction of learning strategies and cognitive styles. Paper presented the $31^{\text {st }}$ LACUS FORUM. University of Illinois at Chicago, July 27-31.

OECD-Organization for Economic Co-operation and Development (2009). PISA 2009 Assessment Framework. Key competencies in reading, mathematics and science. Retrieved Aug. 17, 2010. Available at: www.oecd.org

OISE (2013). Reading/Language. Read, Encode, Annotate, Ponder (REAP). Retrieved Dec. 21, 2013. Available at: http://www.oise.utoronto.ca/aphd/report_writer/ Recommendations_Glossary/READING_LANGUAGE/index.html

O'Malley, J. M. \& Valdez-Pierce, L. (1996). Authentic Assessment for English Language Learners. U.S.A.: Addison-Wesley Publishing Company.

O'Malley, J. M. \& Chamot, A. U. (1990). Learning strategies in second language acquisition. Cambridge: Cambridge University press.

Oxford, R. (1990). Language learning strategies: What every teacher should know. Boston: Heinle \& Heinle.

Oxford, R. (2013). Teaching and researching language learning strategies. New York: Routledge.

Pearson P., D. (1990). Developing expertise in reading comprehension. In: ERIC document 324 648. Retrieved Nov. 29, 2010. Available at: http://www.eric.ed.gov/ ERICDocs/data/ericdocs2sql/content_storage_01/0000019b/80/22/72/89.pdf

Peterson, J. \& Hagen, S. (1999). Better writing through editing. Boston: McGrawHill College.

Pratt, S. (2005). Gravely pregnant with Freireian alternativity: Can foreign language learning avoid reinforcing cultural and social hegemony. In: How Journal. Bogotá: ASOCOPI.

Pushkin, D. (2007). Critical thinking and problem solving. The theory behind flexible thinking and skills development/Pensamiento crítico y solución de problemas, la teoría detrás del pensamiento flexible y desarrollo de habilidades. In: Journal of Science Education (8)1, pp. 13-18. Bogotá.

Robb, L. (2000). Teaching reading in Middle School: A strategic approach to teaching reading that improves comprehension and thinking. NY: Scholastic. 
Scarcella, R. \& Oxford, R. (1992). The Tapestry of Language Learning: The Individual in the communicative classroom. Boston: Heinle \& Heinle.

Sharrio, C. (2011). Lesson Content: Collaboration Website for revising content relevant to the alternative teaching certification program. The Florida Department of Education, University of Central Florida and State College of Florida. Retrieved May 29, 2014. Available at: http://faculty.scf.edu/sharric/lesson8/lesson8topic8.htm

Stokes, S. (2002). Visual Literacy in Teaching and Learning: A Literature Perspective. In: Electronic Journal for the Integration of Technology in Education, (I)1.

Trenado, P. (2004). El entrenamiento estratégico en el aula de L2: Fundamentos, fases y modelos. Retrieved Nov. 29, 2007. Available at: http://www.kandagaigo. ac.jp/kuis/aboutus/pdf/paloma_trenado.pdf

Tague, N. (2004). The Quality Toolbox, 2nd. Edition. ASQ Quality Press. Available at: http://www.asq.org/learn-about-quality/cause-analysis-tools/overview/fishbone.html

Vahle, P. (2006). The case for incomprehensible input. In: Voices: Issue 194, pp. 3-4. London: IATEFL.

Vani, C. (2004). Using interviews with a dramatic tone. Retrieved Oct. 2007. Available at: http://www.teachingenglish.org.uk/try/othertry/

Witt, C. (n.d.). Strategic listening. Retrieved Dec. 5, 2010. Available at:http://www. wittcom.com/strategic_listening.htm

Wenden, A. (1998). Metacognitive knowledge and language learning. In: Applied Linguistics 19(4), pp. 515-537.

Yan Yan, Z. (2010). Investigating the Role of Metacognitive Knowledge in English Writing. In: HKBU Papers in Applied Language Studies Vol. 14, Wuhan University.

\section{Electronic sources}

A+ research and writing step by step. The Internet Public library. www.ipl.org/div/teen/aplus/step5.htm\#5.1\#5.1.

Fish diagrams.

http://www.skymark.com/resources/tools/cause.asp. 
i search quotations.com: Your famous quotes and quotations reference. http://www.isearchquotations.com

ProTeacher Community www.proteacher.org/a/82974_Inferring.html

Resource for teachers www.quia.com

Tree diagram. http://k-8visual.info/xTree.html.

Teacher vision.

http://www.teachervision.fen.com/graphic-organizers/printable/6293.html

Trivia games with audio for beginners.

http://trivia.oddcast.com/discovery.php?door=1

The website k-8visual.info's keywords in search engine.

http://website-tools.net/google-keyword/site/k-8visual.info.

Visual organizers.

http://www.teachervision.fen.com/graphic-organizers/printable/6293.html.

Wordpress.com site. Communicative competence (2011).

http://primrose33.wordpress.com/2011/11/13/communicative-competence/

Writing Center. Youngstown State University.

http://iws.ohiolink.edu/ sg-ysu/critread.html 


\section{Further reading}

This section brings suggested readings and resources that expand on some of the topics.

a. Issues in Teaching and in Testing Language. There are key problems for attaining communicative competence. The first problem we face when validating the levels and the descriptors of communicative competence is that people understand different competence levels differently. What speakers of a language should be able to do at the end of an educational cycle, for example should be a matter of negotiation among the staff of an institution. Activities of needs analysis, of curriculum design and of evaluation might contribute to build a common understanding. Gathering data from testing and assessments can also prove useful. The result would be a proposal for the definition of the levels of command of the target language at the end of an educational cycle, which is based on empirical data. Hopefully the levels of communicative competence that appear in Table I may help to establish what learners are expected to attain with the language, what they can do in the language, and what they would be able to do through language.

A second issue we face deals with the selection of content and the selection of texts. Language programs need to select and organize contents that are in tune with the learners' cognitive development. In addition, these texts need to represent different genres to enrich the learners' literacy experiences.

A third issue we face deals with the selection of tasks learners shall work on. How can they be meaningful? How can they be intellectually stimulating? How can they be purposeful? Programs would need to combine pedagogical and real-life tasks; proposing tasks that have a purpose, a goal or an outcome; and find tasks that are adequate to the learners' immediate needs and interests. Educators also need to find ways to integrate tasks that require information technologies.

A fourth issue deals with testing, assessment, and evaluation (TAE). First of all, TAE has to reflect the teaching being carried out. In my observations as well as in the courses I have taught, TAE is mostly concerned with linguistic competence; there is little concern for other competencies. In some tests for 
adults acquiring an L2 that I analyzed, most items were limited to the word or sentence level. Several items did not specify the communicative situation in which the people are involved. The learner was being asked to apply grammar forms mechanically or asked to use metalanguage. Some items did not call for interpretation or analysis. In general, many items contained discrete point tests in which bits of language rather than holistic language was being tested. Testing items need to go beyond the decoding level; and consider characters, situations, setting, roles, communicative function, or speaker intention. There is a need to measure the learners in relation to processes, contents, and contexts of application a proposed for assessment by the Organisation for Economic Co-operation and Development (2009:1) in its program for international student assessment.

They propose these processes:

Forming a broad understanding; Retrieving information; Developing an interpretation; Reflecting on content of text; and Reflecting on form of text. They also propose to take into account Content (knowledge and understanding): Continuous texts (narrative, expository, descriptive, argumentative/persuasive, injunctive/instructive); Non-continuous texts and visual media: charts, graphs, diagrams, maps, forms, advertisements. And finally, they propose Context of application/situations/domains: Personal, Educational, Occupational, and Public.

The above sub-categories may be used to set the test tasks proposed or may guide language practitioners to propose solutions to the problems involved in the development of communicative competence (See Castillo, 2006). Hopefully an understanding of the issues will help language teachers set goals, create tasks and conduct assessment that better reflect what learners can do with language, in the language and through language. As a corollary it may be said that language pedagogy strives for integrating and processing the constituents of communicative competence and of proposing syllabi in which the textual, the intratextual and the extratextual levels are permanently interwoven.

b. In-Class surveys. The survey below and others can be found at: (http:// www.teachingenglish.org.uk/). This one has been designed for younger learners and is based on the theme of school subjects. 


\section{Class survey - Try - Activities (C BBC | British Council 2007 \\ School Subject Class Survey worksheet \\ School subject class survey name}

1) Hello, What's your name?

2) How are you?

3) How old are you?

4) What's your favourite school subject?

6) What's your worst subject?

7) What is the most important school subject?

Thank you very much, goodbye!

\section{School subjects}

Maths English Art P.E Music Religion Spanish Chemistry Physics

Social studies Science Technology Computer studies

\section{Preparation}

Before the class I speak to a teacher from another group and try to arrange for my class to survey a different class that they don't know. It's a good idea to choose a group who have a higher level than your own group as this avoids misunderstandings in the survey. I tell the teacher that we are going to do a survey on school subjects and arrange a time to go into his/her class.

\section{Procedure}

I tell my own class we are going to do a class survey on another group. The survey is about school subjects and involves asking a student from another class seven questions and then recording their answers on the survey sheet. I usually brainstorm school subjects on the blackboard and check spelling and pronunciation at the same time. Once there is a list of subjects on the blackboard I ask the following questions:-

1) What's your favourite subject?

2) What's your worst subject?

3) What's the most important school subject?

\section{Rationale}

It's a good idea to get the class thinking about school subjects and comparing themselves to others in the class. This activity gives them the chance to practise target language in context and it also prepares them for the survey with students they may not know.

I then do the following things:

-Give out the School Subject Class Survey worksheet

-Read through the questions and check pronunciation

-Elicit answers from the group and check pronunciation

-Ask the group to prepare themselves for the survey with a pencil and a their coursebook to lean on while they are writing answers

-Go to the other group and carry out the survey 
-After the survey I collect answers on the board in our own classroom. This is a good way to bring the activity to a close.

To do this it's interesting to draw a simple vertical bar graph for the last three questions (favourite school subject, worst subject and most important school subject) on the board and ask the class to put up their hands to show what they found out in the survey. Finally I ask why they think English/Maths or Computer Studies is the most important school subject

\section{c. On planning for writing}

Harris, Graham and Mason (2006) research report on writing discuss the relevant literature and make a case for planning to become the central focus of instruction. "First, planning is an essential ingredient in skilled writing; skilled writers spend a considerable amount of time planning what to do and say (Flower \& Hayes, 1980; Graham, (in press); Kellogg, 1987), including setting goals, generating ideas, and organizing ideas into a writing plan (Hayes \& Flower, 1980). Second, struggling writers are less knowledgeable about the strategies and processes involved in planning a paper than their peers who are better writers (Graham \& Harris, 2000). For example, Englert, Raphael, Fear, and Anderson (1988) found that poor writers were less knowledgeable than good writers about how to develop and organize ideas for writing a paper. Third, young writers, including those who find writing difficult, do little planning in advance of writing (Cameron \&Moshenko, 1996; MacArthur \& Graham, 1987). Advanced planning may be especially advantageous for both novice and struggling writers. A written plan provides an external memory wherein a child can store ideas without the risk of losing them. It may further reduce the need to plan while writing, freeing resources to engage in other writing processes such as translating ideas into words and transcribing words into printed text (Kellogg, 1986, 1987, p. 298).

d. Use of interviews as a point of departure for writing. Chauhan, (2004) suggests interviews with a dramatic tone.

Activity: Questioning in role/hot seating involves one of the learners (the teacher could also take on the hot seat in case there aren't any student volunteers) being questioned in a role about their motives, character and attitude to a situation or other people and so on. In literary texts, it can be used to deepen characterization. In case the level of the learners' questions remains literal, or barely relevant, the teacher should intervene and give lead. This technique operates in a controlled manner and is, therefore, very useful for the teacher who is new to drama. Texts about characters who have done heroic feats, lived an adventurous life or been in the news for some reason or the other, can be used for hot seating or questioning in a role. 
Aims of the activity: Comprehension and interpretation of character, taking down notes, practice in report writing

Procedure. The class is told that they are newspaper reporters at a press conference to interview the character after his/her adventures. The 'character' (a learner who has volunteered to take on the role) sits in the front, facing the rest of the class and answers questions posed by the reporters. He is interviewed for no more than 10 minutes. The reporters ask not just questions, but, also take notes in order to write a news story or a more descriptive feature article for the next edition of their paper. In case of a large number of learners in the class, about three learners can team together and pose as reporters from the same newspapers. The activity can be made more dramatic by asking the learners to make their nameplates with newspaper names and display them on their desks. A learner can be given the role of a moderator who introduces the "character" and ensures a smooth functioning of the conference. After the interview is over, the teams of "reporters" work together for the write-up. The learner who has been questioned in the role of the character can join one of the teams of the reporters.

Follow-up. The reports are read aloud in class and the learners discuss with the teacher which are the good ones and why. Good reports are put up on the class wall magazine.

Variations. Different learners can volunteer as the character to be interviewed. Later, the class decides which learner gave the best interview and this interview is used to write the report or the feature article.

Chauhan, Vani (2004)

\section{e. On graphic organizers}

Other uses for the Cause and Effect tool include organization diagramming, parts hierarchies, project planning, tree diagrams, and the $5 \mathrm{~W}$ 's. In the address below you may find a link to a tool to create a diagram: http://www. skymark.com/resources/tools/cause.asp. (Also see Nancy R. Tague's 2004: 247-249.).

An interesting example for solving a complex math problem is presented below.

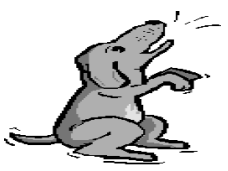

Twenty-four dogs have short tails, and fifteen of the dogs have long hair. There is only one dog that is black with a short tail and long hair. Two of the dogs are black with short tails and do not have long hair. Two of the dogs have short tails and long hair but are not black. If all of the dogs in the kennel have at least one of the mentioned characteristics, how many dogs are black with long hair but do not have short tails? Twenty-four dogs are in a kennel.

Twelve of the dogs are black, six of the dogs have short tails, and fifteen of the dogs have long hair. There is only one dog that is black with a short 
tail and long hair. Two of the dogs are black with short tails and do not have long hair. Two of the dogs have short tails and long hair but are not black. If all of the dogs in the kennel have at least one of the mentioned characteristics, how many dogs are black with long hair but do not have short tails?,

Solution: Draw a Venn diagram to represent the situation described in the problem. Represent the number of dogs that you are looking for with $\mathrm{x}$.

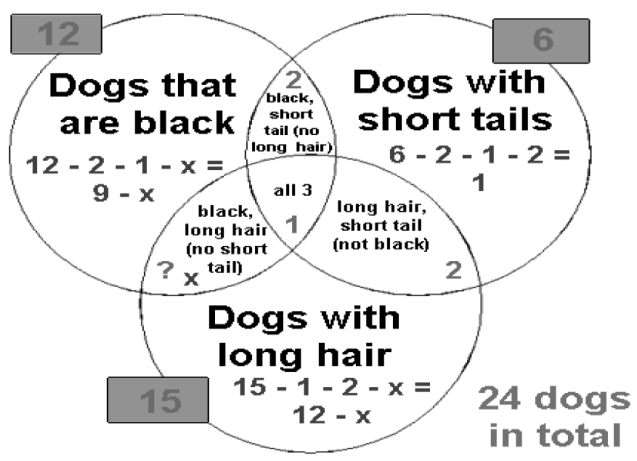

Notice that the number of dogs in each of the three categories is labeled OUTSIDE of the circle in a grey box. This number is a reminder of the total of the numbers which may appear anywhere inside that particular circle. After you have labeled all of the conditions listed in the problem, use this OUTSIDE box number to help you determine how many dogs are to be labeled in the empty sections of each circle.

Once you have EVERY section in the diagram labeled with a number or an expression, you are ready to solve the problem.

Add together EVERY section in the diagram and set it equal to the total number of dogs in the kennel (24). Do NOT use the OUTSIDE box numbers.

$9-x+2+1+1+2+x+12-x=24$

$27-x=24$

$x=3$ (There are 3 dogs which are black with long hair but do not have a short tail.) Notice that the number of dogs in each of the three categories is labeled OUTSIDE of the circle in a grey box.

This number is a reminder of the total of the numbers which may appear anywhere inside that particular circle.

After you have labeled all of the conditions listed in the problem, use this OUTSIDE box number to help you determine how many dogs are to be labeled in the empty sections of each circle.

Once you have EVERY section in the diagram labeled with a number or an expression, you are ready to solve the problem. 


\section{f. On Problem-cause-effect organizers}

Kang (2004) claims that visual organizers are used to present structural knowledge spatially for enhancing comprehension and that they are effective in terms of helping to elicit, explain, and communicate information because they can clarify complex concepts into a simple, meaningful, display. Organizers allow users to visualize the structural concepts of knowledge so that they can develop a holistic understanding of the content. Teachers may use visual organizers before instruction (when making instructional plans) to conceptualize course structure; during instruction (while communicating ideas) to prepare students to approach new information and clarify complex ideas; and after instruction to assess and reinforce. A collection of over 300 ready-to-use graphic organizers can be found at the website Teacher vision. 


\section{Appendix 1}

\section{Nomination of manuscript of this book to an international award.}

THE MACMILLAN EDUCATION AWARD FOR INNOVATIVE WRITING: Lee-Ann Archer, UK., Marta Braylan and Dolores Bereterbide, Argentina., Rigoberto Castillo, Colombia., Irina Kozhukhariova., Russia Gulnissa Makhanova, Kazakhstan Simona Petrescu, Romania.

Visit: http://englishagenda.britishcouncil.org/content/eltons-2011-comunication- station-uic

\begin{tabular}{|c|c|}
\hline $\begin{array}{r}\text { Asunto: } \\
\text { De: } \\
\text { Fecha: } \\
\text { Para: } \\
\text { Cc: } \\
\text { Prioridad: }\end{array}$ & $\begin{array}{l}\text { ELTons } 2011 \text { nominee } \\
\text { Joanne.Stafford@britishcouncil.org } \\
\text { Lun, } 20 \text { de Diciembre de 2010, 5:20 am } \\
\text { rcastlephd@yahoo.com } \\
\text { rcastillo@udistrital.edu.co } \\
\text { Normal }\end{array}$ \\
\hline \multicolumn{2}{|c|}{$\begin{array}{l}\text { We are pleased to announce that you have been shortlisted for the Macmillan } \\
\text { Education Award for Innovative Writing. The short-list will be published on the } \\
\text { ELTons website < http://www.britishcouncil.org/learning-eltons }>\text { this week. }\end{array}$} \\
\hline \multicolumn{2}{|c|}{$\begin{array}{l}\text { We would like to invite you to the ELTons ceremony at } 11 \text { Cavendish Square in } \\
\text { London on } 23 \text { February } 2011 \text {. We will share the results of the competition with } \\
\text { all nominees in advance because the British Council will pay for travel and one } \\
\text { night's accommodation on } 23 \text { February for the award winner. }\end{array}$} \\
\hline \multicolumn{2}{|c|}{ The official invitations will be sent out in January. } \\
\hline \multicolumn{2}{|c|}{ Best wishes and congratulations on being short-listed. } \\
\hline \multicolumn{2}{|c|}{$\begin{array}{l}\text { Joanne Stafford } \\
\text { UK ELT Marketing and Promotion Manager } \\
\text { English Language Innovation }\end{array}$} \\
\hline \multicolumn{2}{|c|}{$\begin{array}{l}\text { British Council | } 58 \text { Whitworth Street | Manchester | M1 6BB | UK } \\
\mathrm{T}+44 \text { (0)161957 } 7651 \\
\text { M +44(0)77757 } 84894 \\
\text { E joanne.stafford@britishcouncil.org }\end{array}$} \\
\hline $\begin{array}{l}\text { Creating opportunity for people } \\
\text { www.britishcouncil.org }\end{array}$ & \\
\hline
\end{tabular}

See more at: http://englishagenda.britishcouncil.org/eltons 


\section{Appendix 2}

\section{Sample assignment for strategy use}

Course: Foundations of Academic English.

Professor: R.C

Workshop for second session. Sample from student 5.

This sample was submitted by a graduate student whose thesis deal with training pre-service teachers in argumentation. The original rubrics appear in italics. The sample illustrates a strategy-oriented approach to teaching and learning academic English.

«Estimados estudiantes: Primera sesión trabajamos sobre estrategias, recursos y herramientas de trabajo para la lectura. Utilizando lo anterior, cordialmente les solicito:

TASK 1. Ingrese a Wordle.net. Pegue su documento de tesis desde la introducción hasta el final, sin la bibliografía. ¿Qué conclusiones saca?

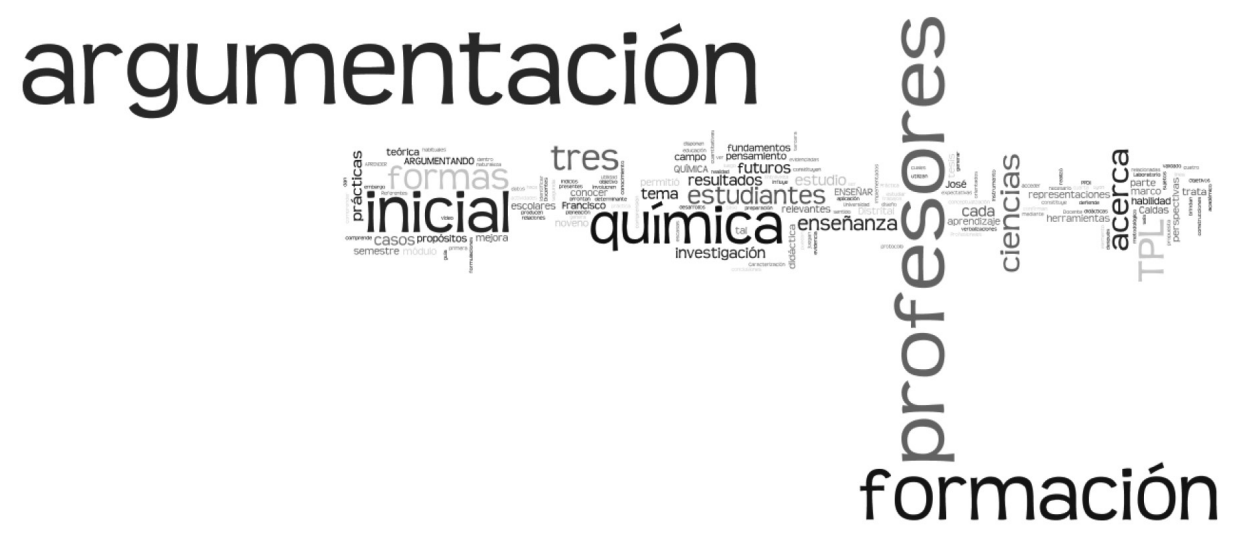

NB: Conclusions were discussed in class. The answers in the sample were shortened to reduce space. The abstract was later revised by this upper intermediate student, who integrated the feedback. 
TASK 2. Pase a lengua inglesa y busque definición en inglés de por lo menos ocho palabras clave de su propuesta de investigación/tesis.

1. Argumentation: the act or process of forming reasons and of drawing conclusions and applying them to a case in discussion.

2. Pre-service teacher training: is the education and training provided to student teachers before they have undertaken any teaching.

3. Professional teaching practice: the use of educational knowledge in a particular context.

4. Representation: the sum or range of what has been perceived, discovered, or learned

5. Interaction: in sociology, social interaction is a dynamic, changing sequence of social actions between individuals (or groups) who modify their actions and reactions due to the actions by their interaction partner(s).

6. Professional development: refers to the acquisition of skills and knowledge both for personal development and for career advancement.

7. Closed question: Question with limited answers.

8. Open question: Question with many possible answers.

Task 3. Personalice temporalmente la herramienta scholar.google.com en inglés. Busque su tema de investigación utilizando las palabras clave arriba identificadas. Use las estrategias de lectura pertinentes para agilizar la lectura de los documentos que encuentre.

KELLY, G., REGEV, J., \& PROTHERO, W. (2007). Analysis of Lines of Reasoning in Written Argumentation. In S. Erduran. \& M. P. Jiménez-Aleixandre. (Eds.). Argumentation in science education: Perspectives from classroom-based research. New York: Springer.

MCDONALD, C., \& MCROBBIE, C. (2012). Utilising Argumentation to Teach Nature of Science. In B. J. Fraser, K. Tobin., \& C. McRobbie (Eds.), Second international handbook of science education. Dordrecht, The Netherlands: Springer.

XIE, Q., \& SO, W. (2012). Understanding and practice of argumentation: A pilot study with Mainland Chinese pre-service teachers in secondary science 
classrooms. Asia-Pacific Forum on Science Learning and Teaching, Volume 13, Issue 2.

Task 4. Levante un glosario de otros 10 términos que encuentre recurrentemente en su tema.

1. Management question: Question related to classroom management.

2. Rhetorical question: Question that doesn't need a reply but are employed for continuity.

3. Theory of cognitive development: A developmental psychology theory developed by Jean Piaget to explain cognitive development. The theory is central to child psychology and is based on schemata-schemes of how one perceives the world-in "critical periods," times when children are particularly susceptible to certain information.

4. Analogies: A thinking skill demonstrated by a student when he or she can give examples similar to, but not identical to a target example. For example, the Internet is analogous to the post office (because in both, multimedia information is delivered to specific addresses).

5. Application Teaching: A constructivist approach centered on activities which involve learning which proceeds from more basic ideas to more complex. The expected products generated by the students are determined by the teacher.

6. Argument Paper: Type of writing which presents a thesis, then supports that thesis with evidence or proof.

7. Argument Table: A table used to organize logical statements. Used in teaching logic in geometry and in expository writing classes.

8. Invention Teaching: A constructivist approach. Students begin learning with an activity (as in Discovery Teaching), but students may generate many possible solutions. Students acquire basic and advanced knowledge in random order.

9. Inventory Questioning: Inventory questions are designed to collect information about students' interests, to activate prior knowledge, or to help students become aware of their existing beliefs and background. Often used when dealing with controversial issues, or in the form of a "personal inventory" to explore emotional problems or limitations.

10. Learning Together and Alone: Cooperative learning approach, as outlined by David W. Johnson and Roger T. Johnson. Unlike other cooperative learning strategies which tend to be periodic activities, "Learning Together 
and Alone" provides guidelines for the creation of a generalized cooperative classroom.

Task 5. Por favor redacte en inglés el resumen de su tesis. No traduzca. Siga una guía como esta: http://www.ehow.com/how_6129635_write-abstract-report.html

\section{Product of an upper intermediate student after the tasks proposed above}

\section{Abstract:}

This article presents the results of a questionnaire designed and applied to 18 chemistry pre-service teachers from a city university Colombia in order to understand their representations of argumentation in science. This research uses the method called Case Study; through the use of this methodology, information is accessed to generate appropriate units of analysis for the production of new knowledge about the argument, which can be articulated to a proposal of theoretical and explicit examples of argumentative content that can be implemented in a curriculum of pre-service chemistry teachers. Results indicate that future chemistry teachers lack appropriate training for promoting argumentation skills in their students. Similarly it was found that future teachers have difficulties to propose classroom activities that promote students' argumentation. Based on the data obtained from the questionnaire, highlights the need to explicitly incorporate academic areas of theory and practice about argumentation in the pre-service science training. The study and understanding of the forms of argument of pre-service chemistry teachers to generate relevant knowledge about argumentation, which would be useful for future theoretical and practical research, carried out as part of the research training and teachers to improve teaching and learning processes of argumentation. 


\section{Appendix 3}

$6 / 6 / 2014$
Quia - Worksheet

Quia ww.quia.com Name

Date

\section{Teaching Effective Reading Strategies}

Fill-in the blanks to test your knowledge of teaching effective reading strategies.

1. When the teacher models or demonstrates how to apply the strategy he or she may use a
display
collaborative
think-aloud
intuitive

2. The most powerful thing we can teach is think, to read, and to write. of the procedures people use to learn, to
intuitive understanding
rote knowledge
alphabetic knowledge
strategic knowledge

3. In direct explanation, the teacher explains
that students are required to use the strategy
why the strategy helps comprehension and when to apply the strategy
the origins of the strategy
the psychological processes underlying comprehension

4. Using teachers can effectively teach any of the NRP's seven comprehension strategies.
direct explanation, modeling, guided practice, and application
induction, explanation, independent practice and assessment
modeling, reading, inference and practice
planning, explanation, practice, and assessment

5. The most effective way to introduce students to how to use reading strategies is to model them in the contexts of and then to assist students in their own use of these strategies
meaningful tasks
classroom discussions
textbook readings
social behaviors

6. Teaching students to code text is one way to scaffold
fluency
metacognition
decoding

http://www.quia.com/servlets/quia.worksheet.WSManager?tagActivityld=1224623\&tagPageTypeCode=pop 


\section{Answers to the Quia Worksheet}

1. Think-aloud.

2. Strategic knowledge.

3. Why the strategy helps comprehension and when to apply the strategy.

4. Direct explanation, modelling, guided practice, and application.

5. Meaningful tasks.

6. Metacognition. 


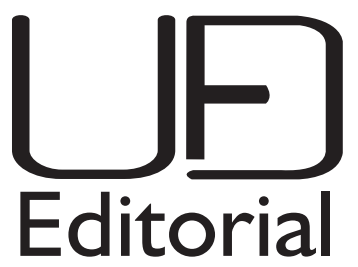

Este libro fue compuesto en caracteres

Optima y Trebuchet MS.

Impreso en 2014

en los talleres de Javegraf.

Bogotá, Colombia.

Castillo, Rigoberto, 1953-

Teaching and learning another language strategically / Rigoberto Castillo. -- Bogotá : Universidad Distrital Francisco José de Caldas, 2014.

123 páginas ; $24 \mathrm{~cm}$.

ISBN 978-958-8832-71-5 / ISBN digital 978-958-8832-72-2

1. Inglés - Enseñanza 2. Enseñanza bilingüe I. Tít. 428 cd 21 ed.

A1447528

CEP-Banco de la República-Biblioteca Luis Ángel Arango 
An earlier version of this book was nominated to the English Language Teaching Awards (ELTons) in England in 2011. It is written to provide information to educators on the nature of language, on the role of language in learning, on the types of knowledge involved in listening, speaking, reading and writing, and on the strategies for academic use in each of those domains. This publication will be useful for teachers of all subject areas. It also aims at building a bridge between first language (L1) and second (L2) teaching.

"The dream of every student shall be in the curriculum, and every teacher shall have $a$ dream as well"

«Elsueño de cada estudiante y de cada docente debe formar parte del curriculon)

Moacir Gadotti (Conferencia del Presidente del Instituto Freire en la Universidad

Distrital, Mayo de 2010).

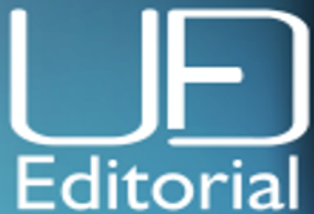

